Final Report

FHWA/IN/JTRP-2002/9

\title{
INTERNET-SUPPORTED EVALUATION OF HIGHWAY SAFETY
}

\author{
by \\ Andrzej P. Tarko \\ Associate Professor \\ Brian R. DeSalle \\ Graduate Research Assistant \\ Purdue University \\ School of Civil Engineering \\ Joint Transportation Research Program \\ Project No. C-36-59CC \\ File No. 8-5-29 \\ SPR-2483 \\ Prepared in Cooperation with the \\ Indiana Department of Transportation and the \\ U.S. Department of Transportation \\ Federal Highway Administration
}

The contents of this report reflect the views of the authors who are responsible for the facts and the accuracy of the data presented herein. The contents do not necessarily reflect the official views or policies of the Indiana Department of Transportation or the Federal Highway Administration at the time of publication. This report does not constitute a standard, specification, or regulation.

Purdue University

West Lafayette, Indiana 47907

July 2002 


\section{ACKNOWLEDGEMENTS}

The authors thank Bob McCullouch and Michelle Leung for developing software for the website prototype and for making all efforts to make the software operate smoothly.

Involvement and advice of the Study Advisory Committee, which consisted of Mike Hougland, John Nagle, Roger Manning, Karen Stippich, and Karen Zhu, helped bring the project to its successful conclusion. 


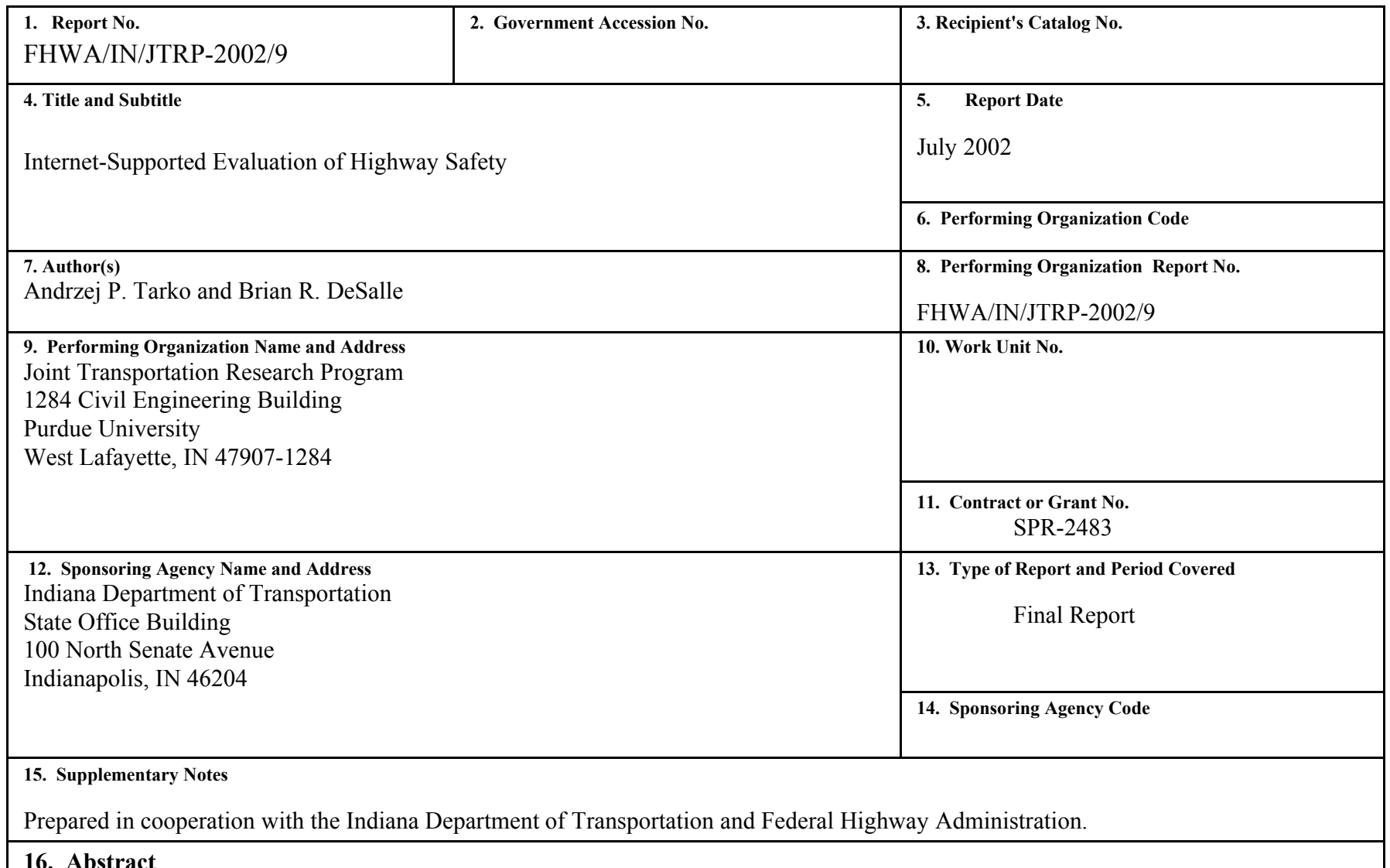

Few current methods of identifying hazardous locations take into account the perspective of highway users. It is generally accepted by human factor experts that user feedback can provide valuable insight into safety at highway locations that is not obtainable through the use of crash data. However, little research has been conducted in the highway transportation area, and the relationship between user perception and actual safety at a location is not well known.

Currently, motorist feedback in Indiana is gathered by individual highway agencies through the use of a phone and mail collection process. A centralized feedback collection would not only make the feedback more readily available to the agencies that could use it, but also more convenient to the user by eliminating the need to determine which agency to contact. In addition, the new collection system needs to be available to the user at all times in order to maximize convenience, something not currently possible through the phone system of collection.

This study addresses this need by investigating an Internet-based prototype tool for collecting motorist feedback. The tool is designed with both the agency goals of efficiently gathering motorist feedback and user-friendliness and convenience in mind. The tool features a database for sorting and collection of responses in a centralized location, making it possible for all relevant agencies to access the information through remote access.

The prototype tool was tested in Tippecanoe County over a trial period of five months in 2001. During this time period, motorist feedback about locations within the county was gathered. It was found that the prototype Internet tool was wellreceived by the public. The safety information gained from the responses to the survey was evaluated by comparing to the crash frequency at the location. From this evaluation, it was found that motorist feedback is a very effective supplement to crash data and can guide highway agencies in the examination and identification of hazardous highway locations.

17. Key Words
Internet-based survey, identification of hazardous locations, highway safety, information technology, motorist feedback, safety investigation

\section{Distribution Statement}

No restrictions. This document is available to the public through the National Technical Information Service, Springfield, VA 22161

\begin{tabular}{|c|c|c|c|}
\hline 19. Security Classif. (of this report) & 20. Security Classif. (of this page) & 21. No. of Pages & 22. Price \\
Unclassified & Unclassified & 157 & \\
\hline
\end{tabular}




\section{TECHNICAL Summary}

INDOT Research

Technology Transfer and Project Implementation Information

\section{Internet-Supported Evaluation of Highway Safety}

\section{Introduction}

Various methods of identifying hazardous roadway locations have been proposed and used. Most of these methods use crash data as a means of measuring highway safety. However, crash data alone does not provide comprehensive safety information. Because of factors such as unreported crashes and time delay in collecting crash data, improving upon the current methods of identifying hazardous locations is desirable.

One possible source of additional safety information is motorist feedback. Currently, the state of Indiana collects motorist feedback about hazardous highway locations through telephone and written correspondence.
In the present study, a prototype Internet survey tool to collect motorists' concerns about highway locations in Tippecanoe County, Indiana is developed. This tool is presented as a means of upgrading the current system of collecting motorist feedback. The tool is designed such that the information provided by the motorist is gathered and presented in an effective manner. The study evaluates the survey tool itself, the quality of the safety information collected with the tool, and the effectiveness of hazard identification based on motorist feedback.

\section{Findings}

Evaluation of the Internet survey tool indicates that users of the survey were pleased with the format and structure of the Internet tool. Eighty to ninety percent of the users indicated satisfaction with the interface, user-friendliness, and readability of the survey tool. Users also indicated a desire for more questions and response options in order to better facilitate their responses. Security and stability of the tool was satisfactory during the pilot study.

Information gathered through an Internet-based survey provides valuable insight into the nature and scope of hazards at highway locations. Responses frequently provide a high amount of detail useful to highway agencies in identifying specific problems upon investigation of a location.

The locations indicated by users tend to be significantly more hazardous than locations not indicated by survey users. If one considers a location hazardous if it has 15 or more crashes during three years, then the respondents altogether identified 45 percent of such locations. The false detection rate was 6 percent. Looking at the detection performance from another perspective, 55 percent of locations reported by motorists were found hazardous. This rate improved to 86 percent for locations reported at least twice, and to 96 percent for locations reported at least three times.

It was also found that gender of respondent had no statistically significant effect on the results. Older motorists tended to perform better than younger motorists in terms of percent of reported locations that were hazardous but this trend could not be confirmed as statistically significant probably due to a small sample size. The collected data support a hypothesis that perception of hazard based on personal observations of traffic and intersection conditions is as adequate, if not better than, safety information obtained from individuals involved in a crash or from the public media. 


\section{Implementation}

Examination of the results indicates that the public is highly receptive to the use of the Internet survey tool as a means of gathering their feedback about the safety of highway locations. The detailed descriptions of safety problems obtainable through the survey would be useful to highway agencies at any level in investigating safety conditions at highway locations. The Internet tool features database storage and remote access capabilities, making a single tool accessible to multiple agencies through access control. In addition, the results indicate that user feedback tend to identify hazardous locations, making the use of such feedback beneficial to highway agencies operating on limited resources for investigating and improving locations on the basis of safety.

\section{Contacts}

For more information:

Prof. Andrzej Tarko

Principal Investigator

School of Civil Engineering

Purdue University

West Lafayette IN 47907

Phone: (765) 494-5027

Fax: (765) 496-1105
It is concluded that no further pilot testing of the tool is needed. Changes to the survey tool should be made based on the recommendations contained within the report. In addition, the implementing agency is free to add any features that they may find useful to their particular needs.

This tool would be best implemented through the INDOT district level offices, with remote database access provided to local MPOs and county and city road departments in order to make the survey responses readily available to them. A mechanism may also be added to automatically route responses to the most appropriate agency for evaluation.

The prototype tool is recommended as an implementation example. It can be seen at Internet site saferoad.cc (for limited time).
Indiana Department of Transportation

Division of Research

1205 Montgomery Street

P.O. Box 2279

West Lafayette, IN 47906

Phone: (765) 463-1521

Fax: (765) 497-1665

\section{Purdue University}

Joint Transportation Research Program

School of Civil Engineering

West Lafayette, IN 47907-1284

Phone: (765) 494-9310

Fax: (765) 496-1105 


\section{TABLE OF CONTENTS}

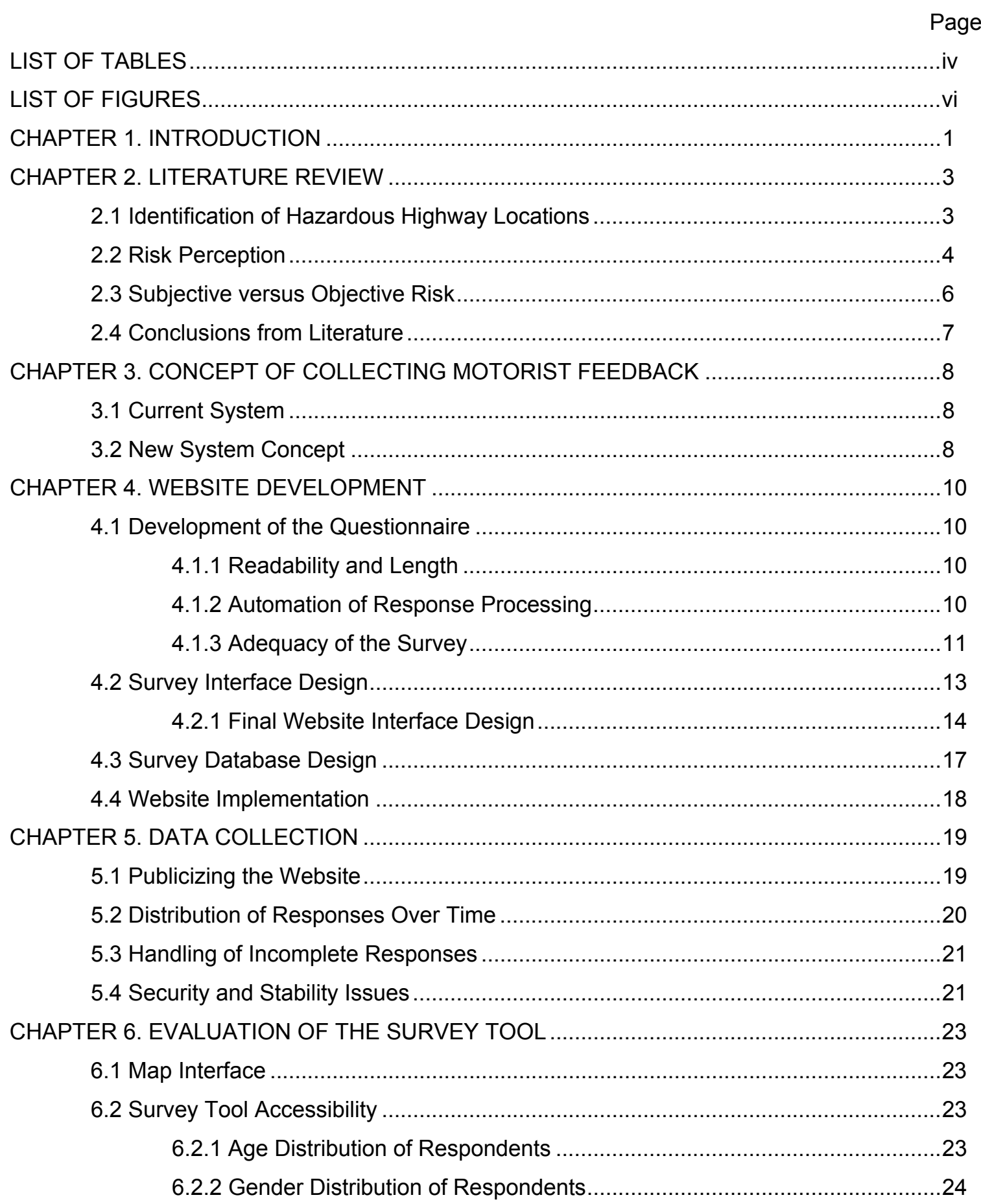


Page

6.3 Evaluation of Survey Questions..................................................................25

6.3.1 Questions One and Two - Location of Concern ....................................25

6.3.2 Question Three - Basis of User Concern .............................................25

6.3.3 Question Four - User-Reported Causes of Safety Problems...................26

6.3.4 Question Five - Frequency of Use of the Location ...............................28

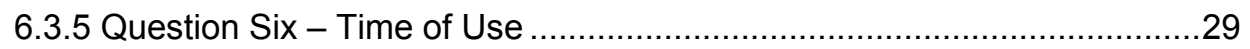

6.3.6 Question Seven - Willingness for Spending Extra Travel Time ..............30

6.3.7 Question Eight - Demographic Information..........................................31

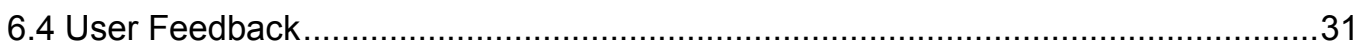

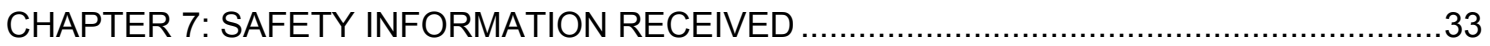

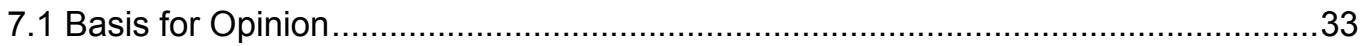

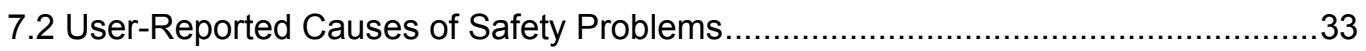

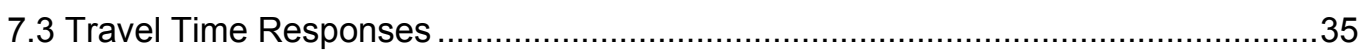

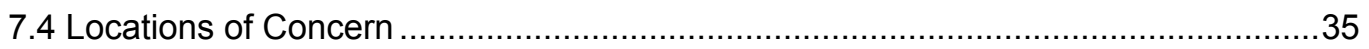

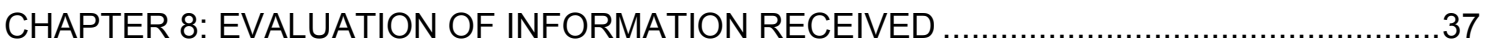

8.1 Are Reported Locations Truly More Hazardous? ...................................................

8.1.1 Binomial Test for Number of Responses ............................................38

8.1.2 Binomial Test for Travel Time Responses ...........................................40

8.2 Evaluation of Survey-Based Detection of Hazardous Locations .........................................41

8.2.1 Definition of Detection Parameters ..................................................41

8.2.2 Results of Detection Analysis ........................................................... 42

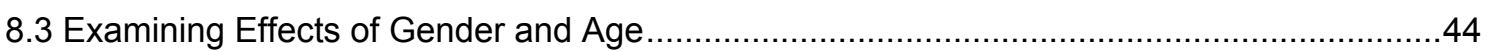

8.3.1 Detection Evaluation for Gender and Age Groups ...............................45

8.3.2 Do Gender and Age Make a Difference? ............................................45

8.4 Non-Crash Personal Perception of Hazard .................................................................. 46

8.4.1 Binomial Evaluation of NCPP Responses ...........................................47

8.4.2 Evaluation of Detection Based on NCPP Responses ............................48

CHAPTER 9: CONCLUSIONS AND RECOMMENDATIONS .............................................

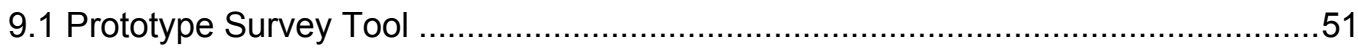

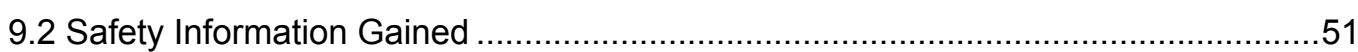

9.3 Evaluation of Information for Pedestrian Purpose ...................................................52

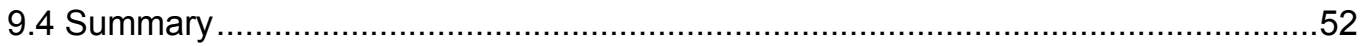

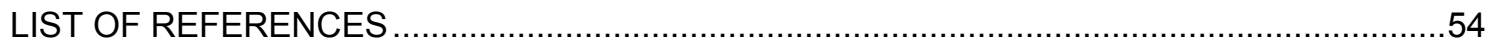


APPENDICES

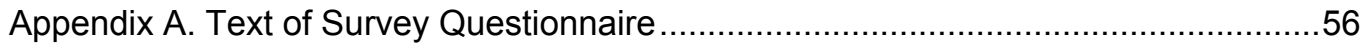

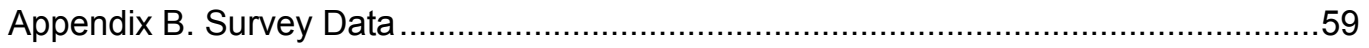

Appendix C. Locations Indicated by Survey Respondents .........................................100

Appendix D. State-Maintained Location Sample with Crashes and Responses ............103 


\section{LIST OF TABLES}

Table

Page

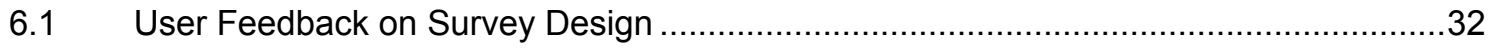

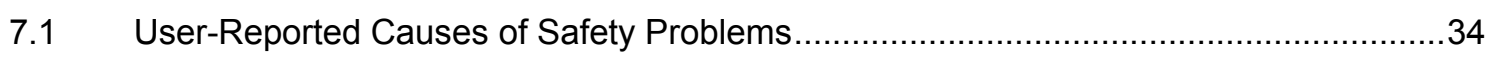

7.2 Top 25 Locations in Terms of Number of Responses ....................................................36

8.1 Groups of Locations Based on Number of Responses per Location.............................38

8.2 Significance Matrix Based on Number of Responses...................................................39

8.3 Groups of Locations Based on Total Travel Time per Location ..................................40

8.4 Significance Matrix Based on Travel Time .................................................................... 41

8.5 Number of Responses and Efficiency Rate for Each Evaluation Group........................45

8.6 Results of Significance Tests Between Groups ...................................................... 46

8.7 Groups of Locations Based on Number of Responses per Location (NCPP) ...............47

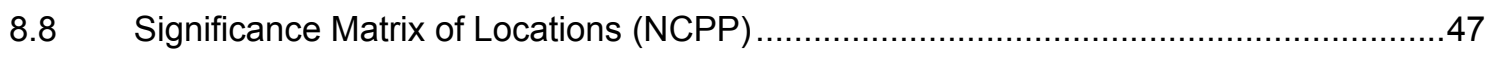

Appendix Table

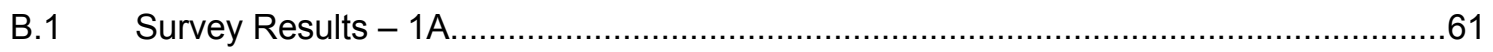

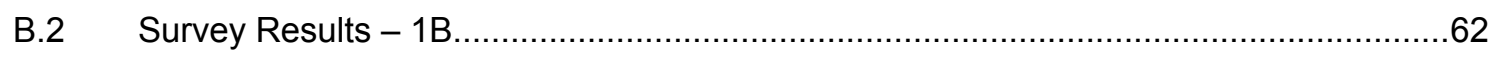

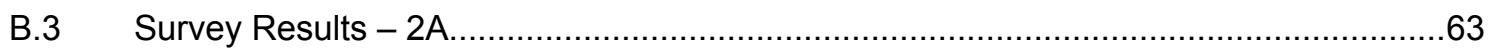

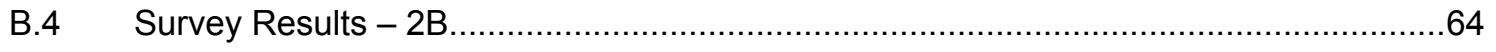

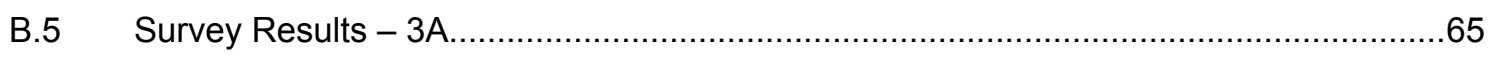

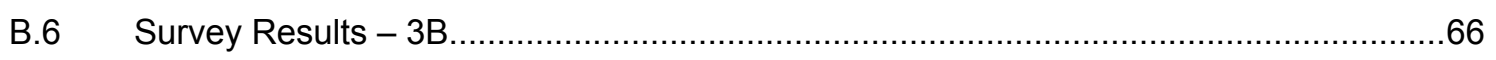

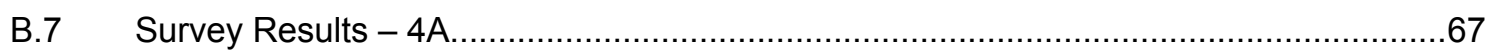

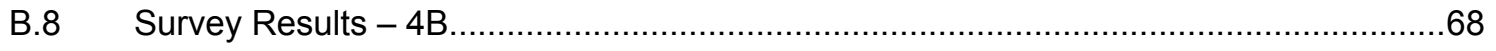

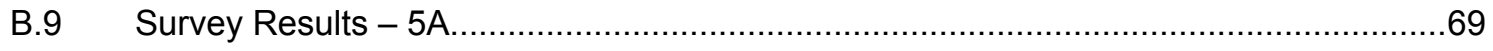

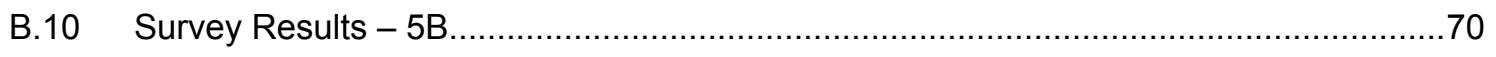

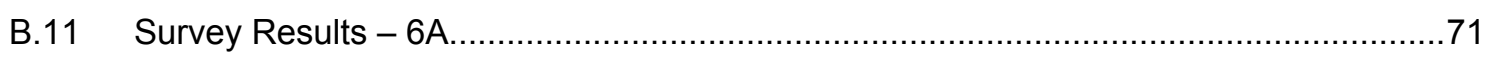

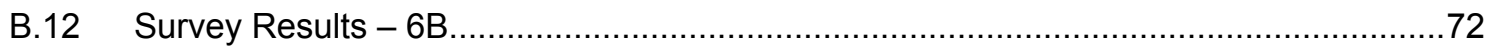

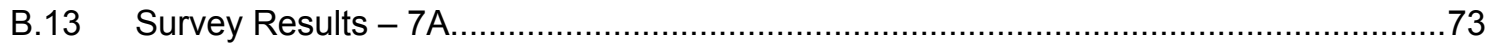

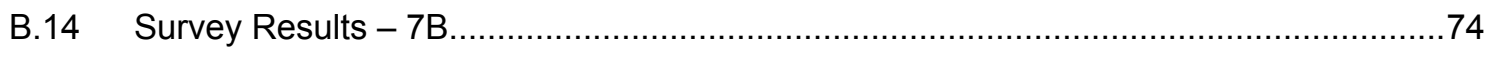

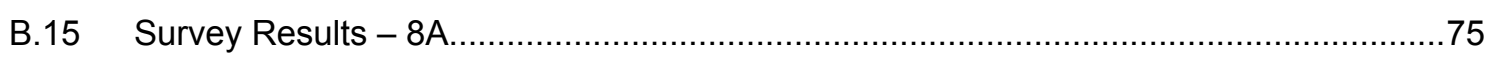

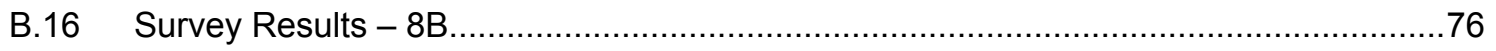

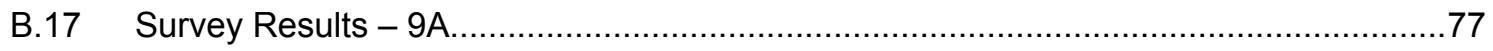

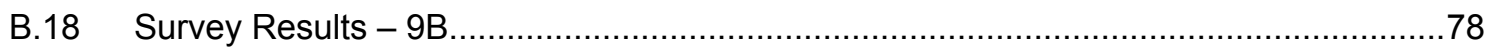


Appendix Table $\quad$ Page

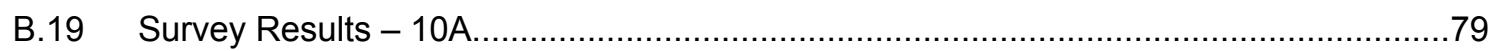

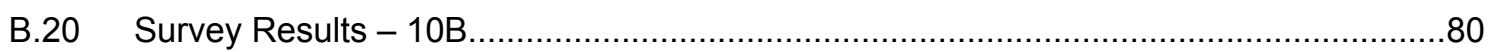

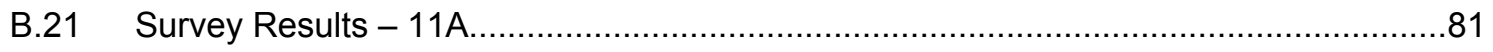

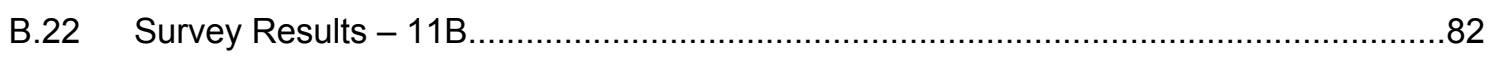

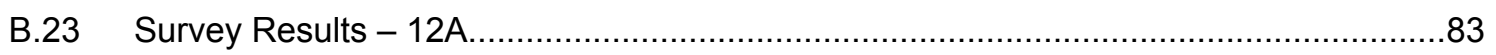

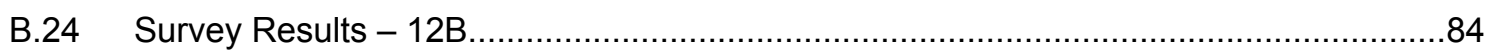

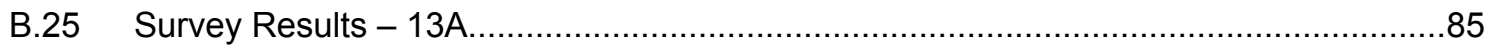

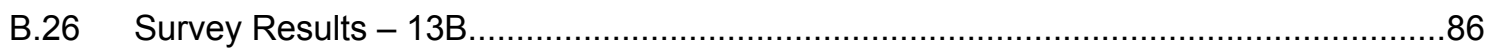

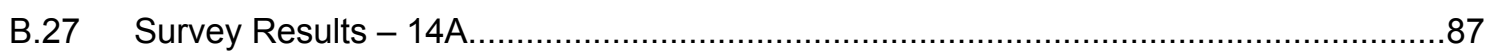

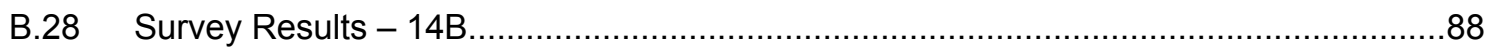

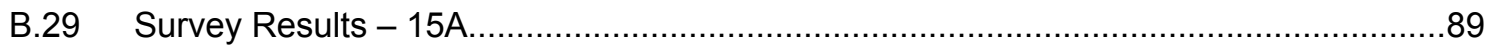

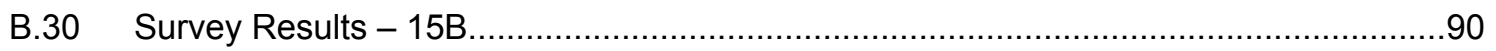

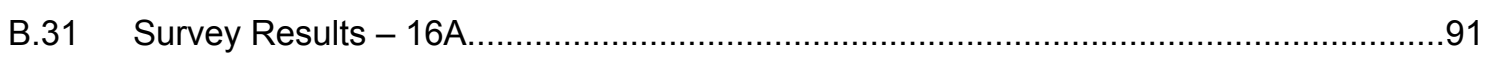

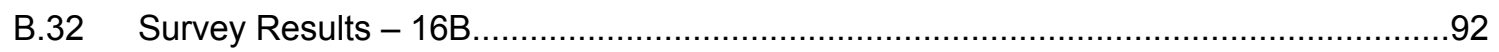

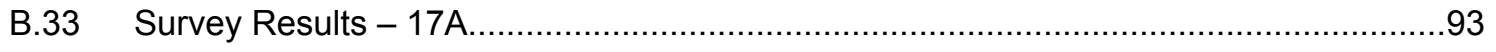

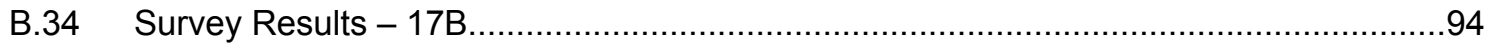

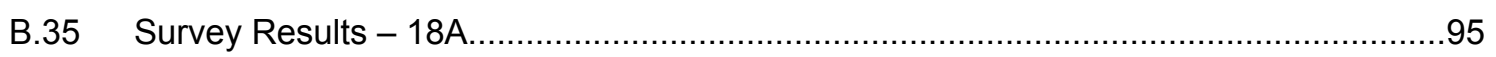

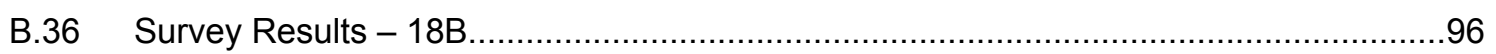

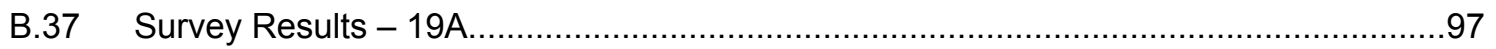

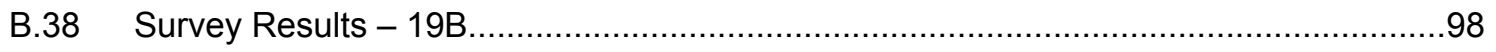

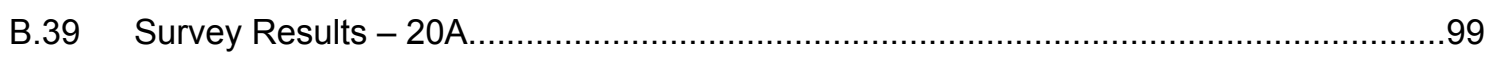

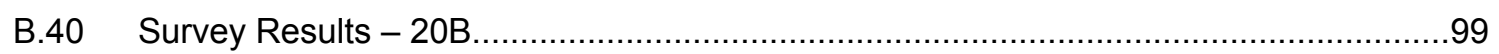

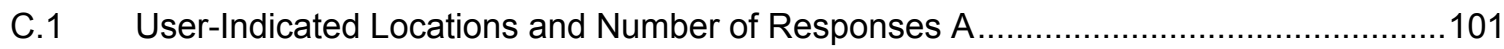

C.2 User-Indicated Locations and Number of Responses B ...............................102

D.1 State-Maintained Location Sample, Crash Totals, and Number of Responses A.........104

D.2 State-Maintained Location Sample, Crash Totals, and Number of Responses B ..........105

D.3 State-Maintained Location Sample, Crash Totals, and Number of Responses C.........106

D.4 State-Maintained Location Sample, Crash Totals, and Number of Responses D.........107

D.5 State-Maintained Location Sample, Crash Totals, and Number of Responses E.........108

D.6 State-Maintained Location Sample, Crash Totals, and Number of Responses F .........109 


\section{LIST OF FIGURES}

Figure Page

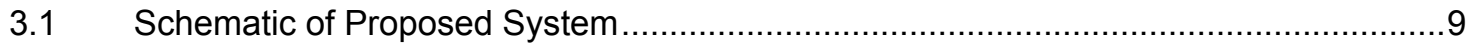

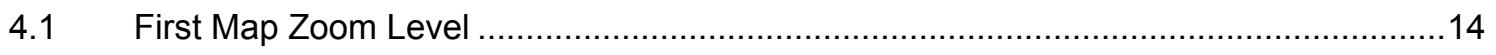

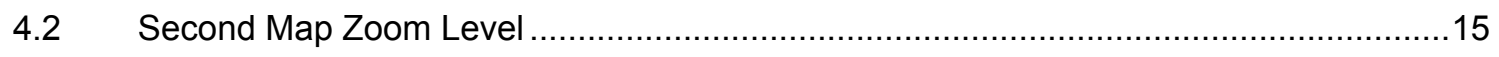

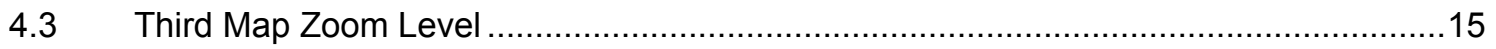

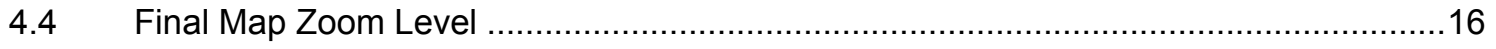

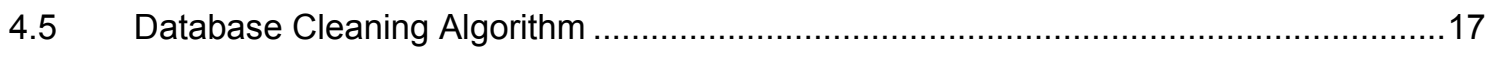

$5.1 \quad$ Newspaper Advertisement to Promote Website ........................................................19

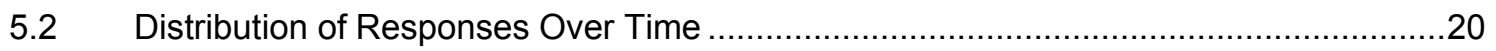

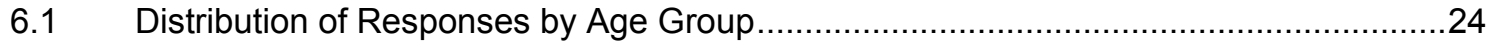

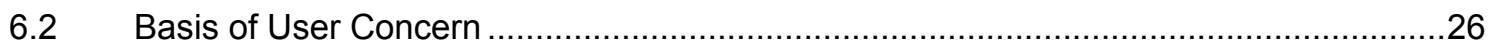

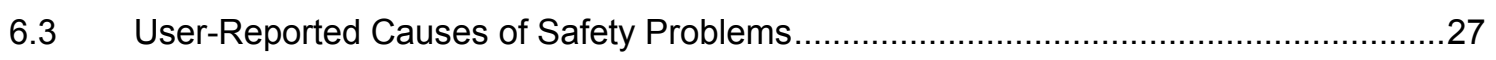

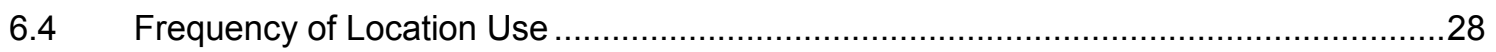

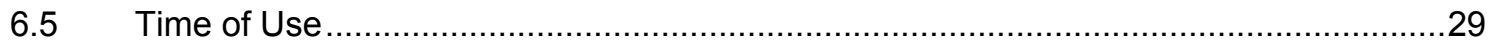

6.6 Respondent's Acceptable Extra Travel Time........................................................ 30

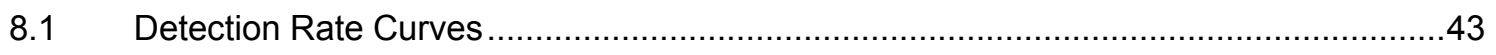

8.2 Efficiency Rate Curves....................................................................................... 43

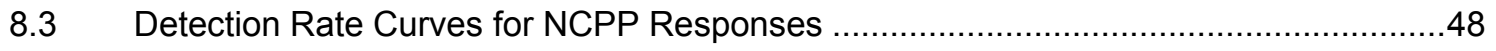

8.4 Efficiency Rate Curves for NCPP Responses ......................................................49

8.5 Comparison of Efficiency Rate Curves Between Information Sets..................................50 


\section{CHAPTER 1. INTRODUCTION}

Many various methods of identifying hazardous roadway locations have been proposed and used. Most of these methods rely on crash data to create a "ranking" of locations suitable for further consideration, although, the use of these methods generally results in an upgrading of many hazardous locations. Randomness in the crash data may cause some locations to be remediated unnecessarily, resulting in waste of agency capital. Further, it takes a reasonably large expenditure of time to gather and compile crash data for an entire area, and thus emerging safety problems may not be apparent for a year or more, until crash data becomes available. Finally, crash reports may not be detailed enough to provide insight as to the nature of a safety problem. It is evident that the crash-based data methods would benefit from the addition of extra information.

Where can additional safety information be found? A survey conducted at Purdue University of 30 local transportation professionals participating in the Transportation Engineering Conference in September 2000 prompts the answer. The professionals were asked what useful data other than crashes and traffic volumes could be used in identifying hazardous locations. Road conditions, sight distance, speed, police citations, and motorist feedback were all potential categories. Interestingly, the use of motorist feedback was looked upon favorably by 57 percent of those present, with an additional 33 percent unsure of the benefit of using motorist feedback. This result is interesting because the state of Indiana does collect feedback from motorists, and thus this data is available for use by the agencies. In addition, it appears that the evaluation of such data is needed, since many professionals are unsure of its usefulness.

Currently, the state of Indiana collects motorist feedback about hazardous highway locations through use of the telephone and through written correspondence. The Indiana Department of Transportation then forwards this information to the local districts for examination of these locations. After examination, the local agency logs their action with the written or electronic correspondence. Obviously, this system requires extra resources for receiving phone calls and letters and for transcribing the information into a usable format. This increases the amount of time expended and the risk of lost information.

Little is known about the usefulness of motorist feedback in evaluating safety at highway locations. This perception is reinforced by a lack of research on the topic. The presented 
research is thought to cover this group. A prototype Internet survey tool to collect motorists' concerns about highway locations in Tippecanoe County, Indiana is developed. This tool is presented as a means of upgrading the current system of collecting motorist feedback. The tool is designed such that the information provided by the motorist is gathered and presented in an effective manner. The study evaluates the developed survey tool, the quality of the safety information that is collected with the tool, and the effectiveness of hazard identification based on motorist feedback.

If the safety information extracted from motorist feedback is found to be valid, it may be used as a supplement to crash data. Unlike the crash database, the survey tool collects motorist responses and makes them available to the agency in a timely manner. The motorist feedback may address randomness in the crash data by more effectively targeting locations that are truly hazardous. Finally, the motorist feedback may carry information about specific problems that helps investigators pinpoint causes of safety problems at a location.

This thesis is organized into nine chapters. An examination of past research in the area of risk perception and hazardous locations pertaining to this study is presented in the next chapter. The concept behind the Internet-based tool for collecting motorist feedback is discussed in Chapter 3 . The design and implementation of the prototype survey tool is discussed in Chapter 4, and the process of data collection is reviewed in Chapter 5 . Chapters 6 and 7 discuss the evaluation of the survey tool based on the collected data and the safety information extracted from the data. Chapter 8 evaluates the information provided from the motorist feedback and how accurate the information is in identifying hazardous locations. Finally, Chapter 9 discusses conclusions and makes recommendations based on the results of the study. 


\section{CHAPTER 2. LITERATURE REVIEW}

The intent of this chapter is to review the existing literature concerning identification of hazardous locations, risk perception, and subjective and objective measures of risk. All of these topics have some bearing on the research at hand, and the articles involving each topic will be discussed in the order listed above.

\subsection{Identification of Hazardous Highway Locations}

A good deal of research has been conducted on various methods of identifying hazardous highway locations. All of this research has a bearing on the current study because one of the objectives of this study is to examine the effectiveness of using motorist feedback to supplement crash data methods of locating hazardous highway locations.

The first study examined in this section was conducted by Spring and Hummer who developed a method to identify hazardous locations using a knowledge-based GIS system (Spring and Hummer, 1995). The method extracts accident data and integrates the accident data with other data, geometric data being one example. The method uses expert knowledge obtained by interviewing outside the local agency. A significant relationship was found between the locations identified by GIS as hazardous and the locations tagged for improvement by the local agencies. This study indicates that expert knowledge carries valuable information about safety at locations that can be used to improve safety management.

The next study examined was conducted by Stokes and Mutabazi (1996) who analyzed the ratequality control method of identification of hazardous locations. The main finding of the paper is that the rate-quality control method as it is currently being used may not be completely appropriate because of simplifications that violate the underlying assumptions of the original method. The authors propose to reinstate the original procedure, with its factors and formulae, and place the responsibility of adjusting the procedure for each individual case solely upon the investigator. The study illustrates the importance of careful examination of the underlying sources and assumptions involved when borrowing methodology used elsewhere.

Hauer (1996) provided an extended discussion of available methods. To summarize his discussion, it can be said that the major problems the crash-based identification encounters is the 
randomness of crash counts and the lack of other data that could support the identification process. These weaknesses of the crash-based approach have remained unsolved.

The last study examined was a study conducted by Chen and Wang (1997). Their study consisted of the comparison of many existing techniques for the identification of hazardous locations and the development of a new technique of identification. The authors compared the direct use of measures such as accident frequency and accident severity, as well as more advanced techniques such as accident matrix methods and the rate-quality control method. The research argues that all of the traditional methods of identification are flawed in that some do not consider length and volume of section, and some do not consider accident severity, while the authors feel that all of these factors are important in determining whether a section is truly hazardous.

\subsection{Risk Perception}

Risk perception is an important concept of the present study where the public is asked to communicate the risks that they perceive at highway locations. Cohn et al. (1995) examined the differences in risk perception between adolescents and adults. Adolescents were found to be more optimistic about their vulnerability to risk, and generally felt less risk than their parents did. The study found that adolescents were not necessarily more willing to take risks, but simply regarded their behavior as less risky. This result contradicts the common opinion that teens are more reckless; in actuality, they just do not see the risk they are exposing themselves to. The results of this study may have an impact on the present research in that the ratings of hazards at highway locations given by younger respondents may be lower than for older respondents.

The next three studies, conducted by Gustafson (1998), DeJoy (1992), and Greenberg and Schneider (1995), dealt specifically with the role of gender in risk perception. Gustafson used a theoretical model based on gender theory. He postulated that gender roles in society influenced risk perception. The proposed new theory was not verified experimentally. In the second study, DeJoy limited his study to younger drivers. He found that males were more optimistic than females about their driving abilities, and that males perceived less risk than females. Young drivers as a whole were found to feel that the risks did not apply to them personally, which was consistent with the findings by Cohn. The third gender-related study by Greenberg and Schneider studied the difference between gender risk perceptions in stressful and non-stressful environments. The study focused on the risk perceptions of people living in neighborhoods with 
many environmental and/or social hazards. The results of the study showed that in stressed neighborhoods, women and men did not have a significant difference in their perceptions of risk, whereas in low-stress neighborhoods, women were significantly more concerned than men were. The results of the three studies on gender indicate that women may rate the highway locations as more hazardous than do men.

Daniels et al. (1992) investigated the public's willingness to pay for safety improvements. The study found that dread and severity played key roles in the public's willingness to pay for improvement in the less-defined risks, while personal exposure was the strongest factor in the willingness to pay for improvements in well-defined risks. Because driving hazards are welldefined hazards, this study shows that drivers may look at personal exposure in their judgment of willingness to pay for roadway improvements. The study is important to the present study because it prompts the possibility of measuring the perceived risk.

Sjöberg (2000) examined some of the theories behind public risk perception (Cultural Theory, general values, and the psychometric model). He proposes a new model where attitude toward a hazard drives risk perception, risk sensitivity is the natural tendency of people to be concerned with hazards, and specific fear regards the fears directly associated with any type of action or technology. The new theory holds promising results, but still has problems explaining all the aspects of risk perception. This provides some understanding of what drives the perception of highway risk.

Liu et al. (1998) investigated the change in public risk perception resulting from information provided to the public through the media. The study found that the time of public reaction to positive information about a hazard is much longer than the public reaction to negative information about a hazard. A public reaction to positive media coverage is also much weaker than the public reaction to negative media coverage. This study implies that locations with a recent accident covered in the media may be more frequently reported by motorists due to the negative media coverage, which may lead to overestimation of the hazard at these locations.

A study investigating the issues related to reporting hazards by agencies and the public response to the hazard information was conducted by Sandman et al. (1993). The study found through three controlled experiments that the public became more outraged and regarded hazards as more dangerous if they felt that the agency was trying to hide information from them or was uncooperative, and that the amount of the technical information provided to the public was not 
nearly as important as the method by which the agencies communicated with them. The study illustrates the importance of trust between the public and governmental agencies.

A study conducted by Renge (1998) examined risk perception, confidence in driving, and choice of speed for a diverse group of drivers. The study found that more experienced drivers perceived hazards more correctly than those with less experience, were more confident in their driving abilities, and evaluated risks better and drove at lower speeds in high-risk situations. Also, male drivers were found to be more confident in their abilities and evaluated the risks as less than their female counterparts. It was also found that drivers performed worse when driving at night than during the day. The current study may show some bias towards more experienced and female drivers if the results of the Renge study hold true.

The final study mentioned here was conducted by Salter et al. (1993), who also investigated risk perception and competition for road use. The study found that the drivers perceived risks well in correlation with the actual accidents along the roadway; however, they did not correlate at all to pedestrian accidents along the roadway. Thus, drivers may not accurately perceive pedestrian risk. The higher risk ratings of the drivers corresponded to situations where the driver was subordinate to other road-users and anticipated the possibility of evasive action to avoid accidents. This study indicates that drivers may tend to identify locations as hazardous if they are exposed to the hazard themselves.

\subsection{Subjective versus Objective Risk}

Fleming and Lardner (1999) studied the causes of the difference between subjective and objective risks. They concluded that people tend to overestimate the risk of situations that have a reputation for being dangerous, particularly if the situations do not happen frequently. In the reverse circumstance, people tend to underestimate the risk. The paper brings up a point pertinent to the current research, namely, that the drivers who go past a location frequently without experiencing a crash may not acknowledge it as hazardous. This phenomenon and the opposite phenomenon of passing a location once and witnessing an accident, or hearing about a location in the media frequently may cause some bias in the results of the present study.

The final work discussed here is a study conducted by Kanellaidis and Dimitropoulos (1994) regarding the subjective and objective evaluation of risk on highway curves. The study found that the subjective risk ratings were systematically higher than the objective risk ratings based on 
design standards. The authors concluded that this is more due to the strictness of the design standards used rather than overestimation on the part of the drivers. The authors also concluded that the difference in the ratings is important because the locations with the greatest difference in ratings corresponded with high accident locations. Their research is shows that there may be a relationship between subjective and objective risks on the highways.

\subsection{Conclusions from Literature}

In conclusion, it is apparent that subjective risk estimates are not used often, if at all, in pinpointing hazardous highway locations. Because of this fact, the proposed research is needed. It is also seen after reviewing the literature that gender, age, driving experience, socioeconomic status, and media coverage may play an important role in shaping individuals' opinions about highway safety, and these impacts may need to be examined carefully. Finally, from reviewing the literature, it appears that little research has been performed to examine the relationship between subjective and objective risks in regard to highway safety. It is hoped that the presented research can fill this gap in knowledge. 


\section{CHAPTER 3. CONCEPT OF COLLECTING MOTORIST FEEDBACK}

The literature review indicates that a system that conveniently facilitates collection of public concerns may assist transportation agencies in determining the safety problems at highway locations.

\section{$\underline{3.1 \text { Current System }}$}

The Indiana Department of Transportation (INDOT) collects user concerns through a telephone complaint system. As complaints are received at INDOT offices, the safety and inspection history of the location is evaluated, and, if deemed appropriate, a study is conducted at the location. Then, the results of the study and any remediatory measures taken are logged with the complaints in order to consolidate the information about the location. This provides the agency with a comprehensive list of complaints and the measures taken to correct the situation so that proper decisions can be made if further complaints are received.

\subsection{New System Concept}

A new system is proposed which uses information technology, namely the Internet, to collect user complaints and compile them into a database. This database can then be accessed by the administering agency and the complaints examined in order to determine which locations need to be analyzed, as well as information gathered as to possible causes of the situation at the location. Figure 3.1 shows the structure of the proposed system. The phone-based system should be retained to provide a communication means to those who do not use the Internet. The phone and written reports could be easily entered into the Internet-based system. 


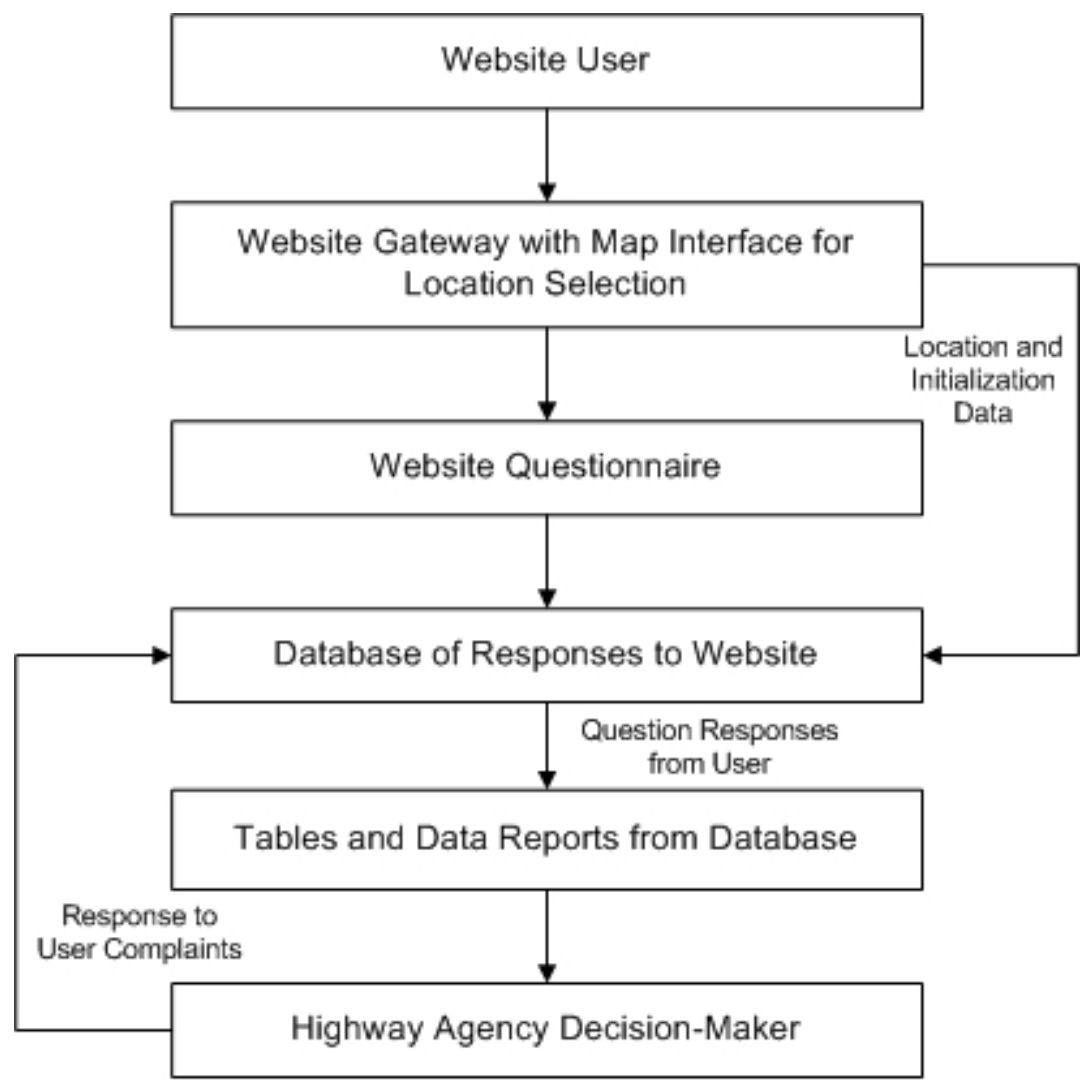

Figure 3.1 Schematic of Proposed System

The schematic shown above depicts the general flow of information between the website respondent and the highway agency. The website user begins accessing the website with his/her web browser. From here, the user interacts with the map interface to locate and select the location of concern. This results in GIS coordinates of the selected location being passed to the database to identify the location and to place a unique identification string in the response record. Then, the user is given access to the website questionnaire, and after completion, the responses are submitted into the prepared record field in the database. From the database, the highway agency can create table and data reports to obtain the survey responses in a usable and readable format. In addition, the agency can also log their response to the concern back into the database, updating the record for each location being reported by motorists. The following chapter discusses in more detail the development of the map interface, website questionnaire, and database. 


\section{CHAPTER 4. WEBSITE DEVELOPMENT}

One of the central objectives of this research was to create an Internet webpage with a survey tool that utilizes existing new technologies to easily collect the opinions of highway users as to which highway locations were hazardous. In developing the website for this research, two distinct phases of the website development evolved: development of the questionnaire, and development of the Internet interface to the questionnaire. This report discusses these two phases in detail.

\subsection{Development of the Questionnaire}

To make the prototype tool successful, the development of the questionnaire followed several design requirements as listed below:

- Readable

- Short

- Allowing Automation

- Adequate

\subsubsection{Readability and Length}

Questions needed to be easily readable and short in length so that the users of the survey tool would not be discouraged by the length of the questionnaire and could understand the questions. If the questionnaire were too long or the questions were not clear, then it would result in some respondents not filling it out, filling it out incompletely, or, in the case of hard-to-understand questions, not giving answers adequate to the intentions of the survey. Problems such as these could result in the loss of important information. A short survey with questions that are easily read and understood is thus necessary to obtain a high return rate and good quality information.

\subsubsection{Automation of Response Processing}

The next objective was to automate the survey tool, so that the data could be automatically stored in a database and then accessed and analyzed. This automation was accomplished by making most of the questions in multiple-choice form, with only a few open-ended questions. This format allows for automatic storage of responses for each survey. This format also reduces response 
time of the respondent, which aids in accomplishing the goal of reduced length as well. An attempt was made to develop questions that lent themselves well to the simplified answering system, and yet still got the desired information from the respondent. This will be discussed further in the following section.

\subsubsection{Adequacy of the Survey}

The final objective, and possibly the most difficult to accomplish, was developing questions that sought information desired. There were certain issues that needed to be considered by the questionnaire developers to make the survey meaningful:

- Measures of the hazardousness of a location

- Reliability of the responses

- Assisting the agency in identifying the causes of the hazard

The rest of this section discusses the issues listed above and the specific questions in the questionnaire that address them. A text form of the questionnaire is included in Appendix $A$ at the end of this report.

Addressing the issue of measuring the hazardousness of a location, a number of ideas were considered, mostly involving willingness to pay for avoidance of the hazardous location. The use of willingness-to-pay measures in highway safety was proposed in previous studies (Daniels et al., 1992). Using monetary values was decided against, on the basis that respondents might suspect a possibility of an increase in taxes or some other negative monetary impact. Since negative connotations in the survey were not desired, it was decided that additional travel time a respondent is willing to spend to bypass the location would be a suitable substitute. Drivers often spend extra time to avoid unpleasant driving situations, thus this measure seems to be a natural choice. The longest additional travel time was expected to be around 10 minutes. This represents a significant amount of extra travel time when traveling in the Lafayette area and in Tippecanoe County. The travel times were then scaled off at increments of two minutes, producing a graduated scale for responses. It is understood that a higher travel time corresponds to a more severe hazard. The measure of travel time provides a quantifiable representation of risk, which can be used in comparisons with accident data. In the questionnaire, this question is included as Question 5. An additional measure of the hazardousness of a location is the number of total responses for that location. Both the travel time reported by each respondent and the 
total number of responses provided a representation of the perceived risk of the motorists at the location, and addressed the issue of measuring the hazardousness of a location.

The next issue was to provide some mechanism to check the reliability of motorist responses. Unreliable responses needed to be either discarded or weighted less than more reliable responses in order to get the best possible measure of hazardousness for each location. Since the objective was to obtain independent responses, and not responses influenced by outside sources or the media, it was decided to include a question that asked the respondent how they had determined that the location was dangerous (Question 3). The purpose of this question was to determine the source of their information, with personal experience treated as more reliable and significant than the other responses. Second-hand information was treated as the least reliable, since it was possible that respondents regarded the intersection as hazardous based only on what they had learned from the media or from friends and relatives. The study conducted by Liu et al. (1998) illustrated how the influence of the media could drive public risk perception in a negative sense.

The second question involving reliability asked for personal information about the respondent, including the home zip code (Question 8). If the zip code is located far outside the county or is missing, the response might not be reliable, depending on the commuting characteristics of the region. The goal here was to reduce the number of responses that are obtained by random wanderers onto the web page or people seeking to intentionally provide bad responses. Another question addressing reliability was the question about the frequency of passing the intersection by the respondent (Question 6). Answers to this question needed to be interpreted very cautiously, since more frequent users may also become lax in their interpretations of risk at the intersection. However, if a frequent user has a perceived high level of risk, this may definitely be a good indication of a problem at the location.

Finally, Questions 4 and 7assisted the agency in identifying the causes of the hazard at locations. Question 4 listed several possible causes of the safety problems at the location. Question 7 asked about the time of day when the respondent passed the location. This question can address night visibility and traffic considerations. Both of these questions provide information that is typically not present in crash data.

Some of the other information, such as age and gender, were used in the study to examine possible relationships between these variables and risk perception. In addition, the feedback 
section at the end of the survey was used to help improve the survey and its functionality to the respondents, and may be omitted once the survey has been revised to the liking of the agency and the respondents. The first two questions of the survey refer to the survey interface, which will be discussed in the next section.

\section{$\underline{4.2 \text { Survey Interface Design }}$}

A number of options were discussed in designing the Internet interface for the questionnaire. These included manual input of locations, selection of locations from a static map, and selecting the location from a fully dynamic mapping tool. The manual input of locations was abandoned because some respondents might not be able to remember the exact location of concern, but might know it by landmarks or distance from major highways. In addition, the manual input of locations alone does not allow effective integration of the collected data with other data present in the existing crash databases and other agency records.

If GIS is used in the future, then a map interface with coordinates of locations can help integrate the survey responses with other data. In addition, a map interface provides the respondent with a visual method of selecting their location(s) of concern. A static map interface consists of a series of maps of the area, cut into a grid pattern. Each map grid square links to a grid on the next lower zoom level, providing more and more detail as the respondent progresses through the levels. The zoom levels are not automated in the static map case, and fine adjustments in the map are not possible. The lowest zoom level consists of a final detailed map with the desired coordinate system programmed into the map image. The static map interface has the benefit of using map images that are small in size and load quickly. The disadvantages of the static map interface are that locations are not searchable, and that preparing the map images requires time and labor.

The dynamic mapping, with automated zoom levels and searchable locations, was given great consideration, but at the time of the research it was cost-prohibitive for the prototype phase. In addition, the load times for the dynamic maps are long, which can discourage respondents from the survey. Thus, the dynamic maps were not chosen to be used for the website interface, however, they may be considered in the implementation of the final version as the technology continues to evolve and becomes more cost-effective. Both the manual input and static map options were combined to create the interface for the prototype questionnaire. Questions 1 and 2 of the questionnaire facilitate the manual input. 


\subsubsection{Final Website Interface Design}

The final website design for the Tippecanoe County pilot website consisted of a static county map broken into 16 sections, and viewable at three levels of zoom (four for the West

Lafayette/Lafayette city areas). The screen captures in Figures 4.1-4.4 illustrate the selection of a location from the top map level down to the final location selection. The map square being selected in each screen capture is shaded.

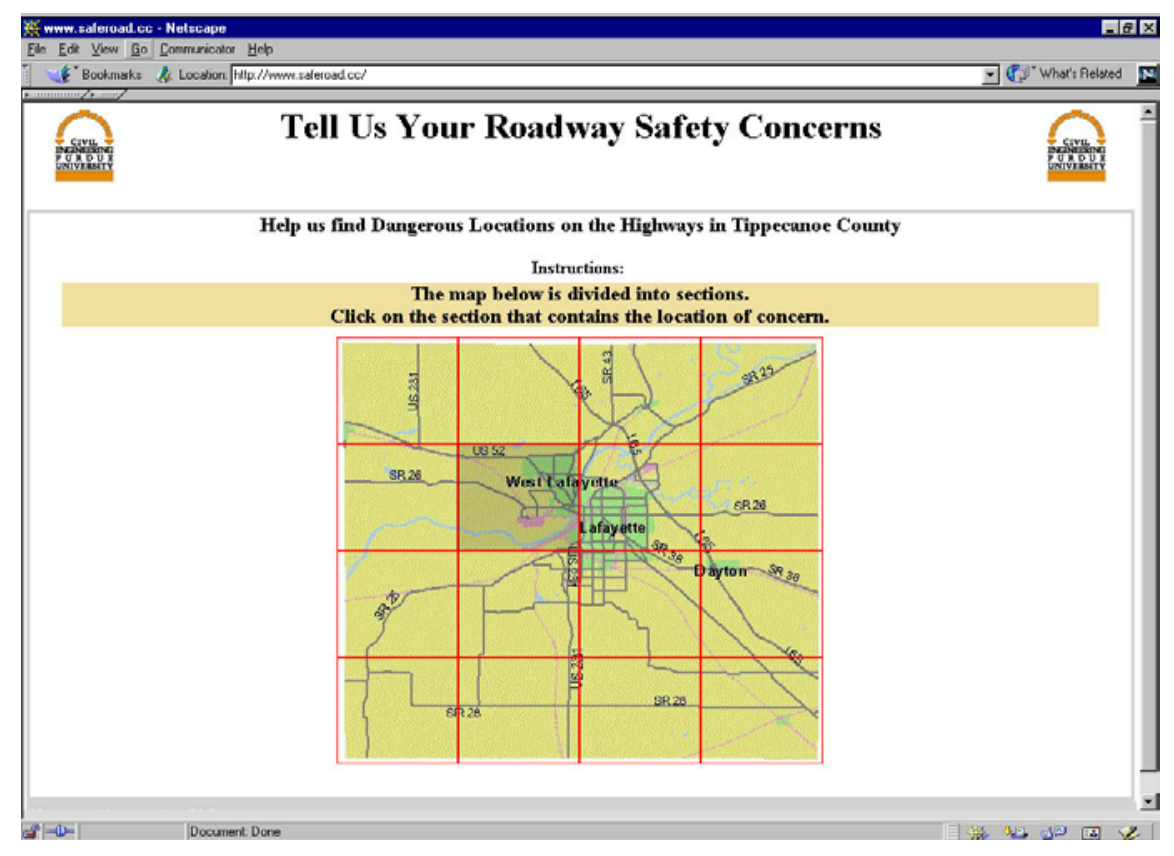

Figure 4.1. First Map Zoom Level 


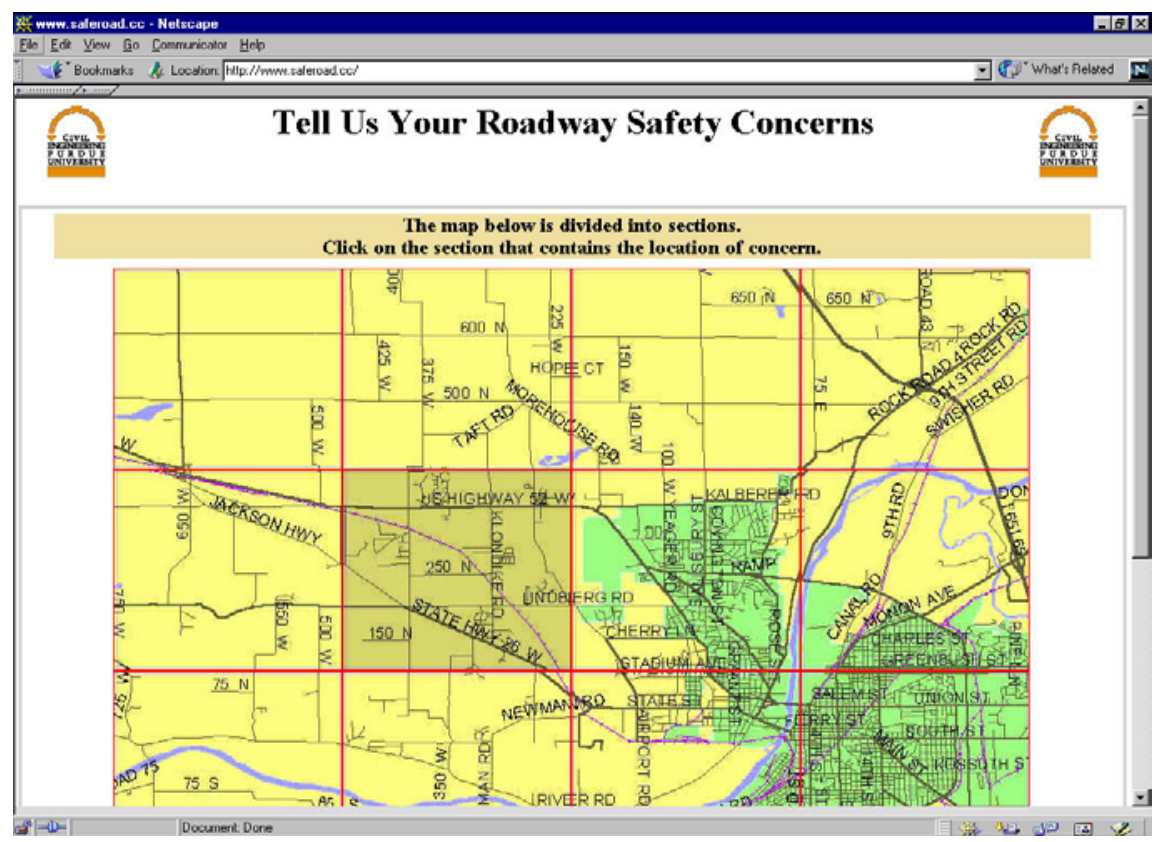

Figure 4.2. Second Map Zoom Level

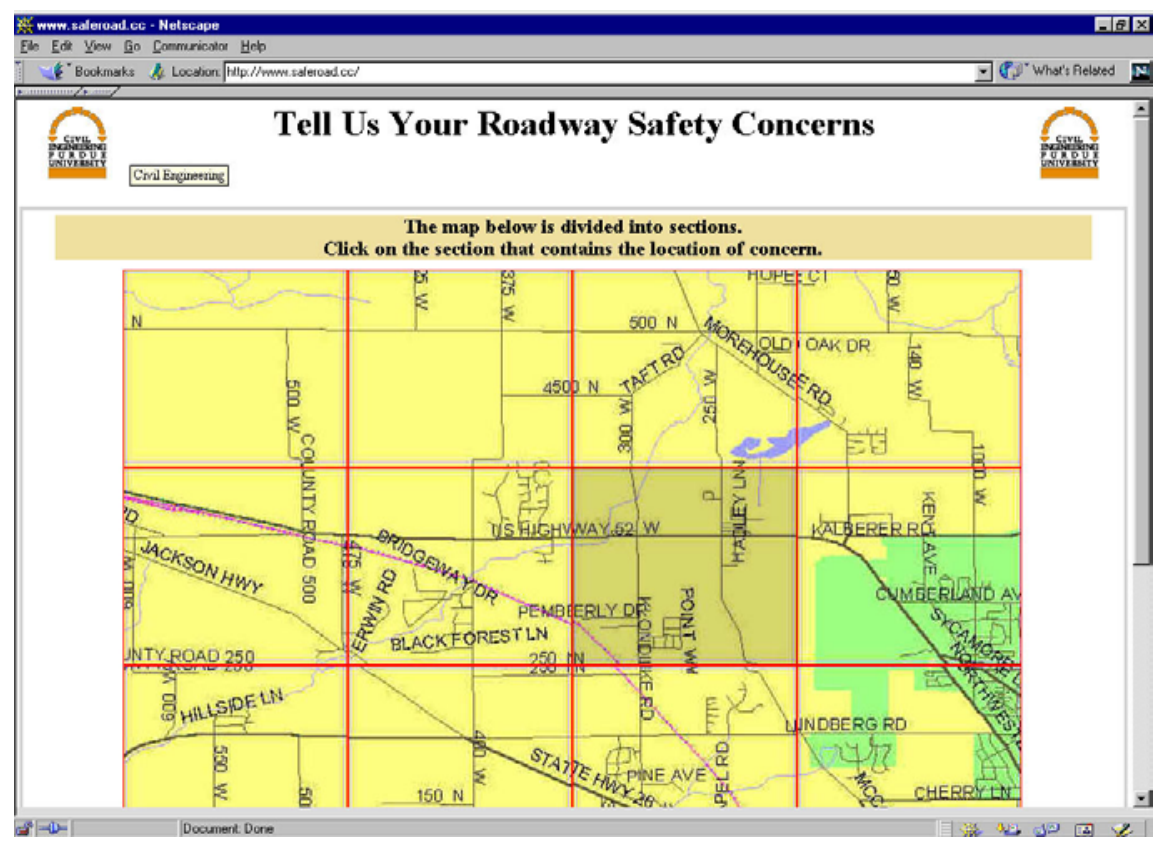

Figure 4.3. Third Map Zoom Level 


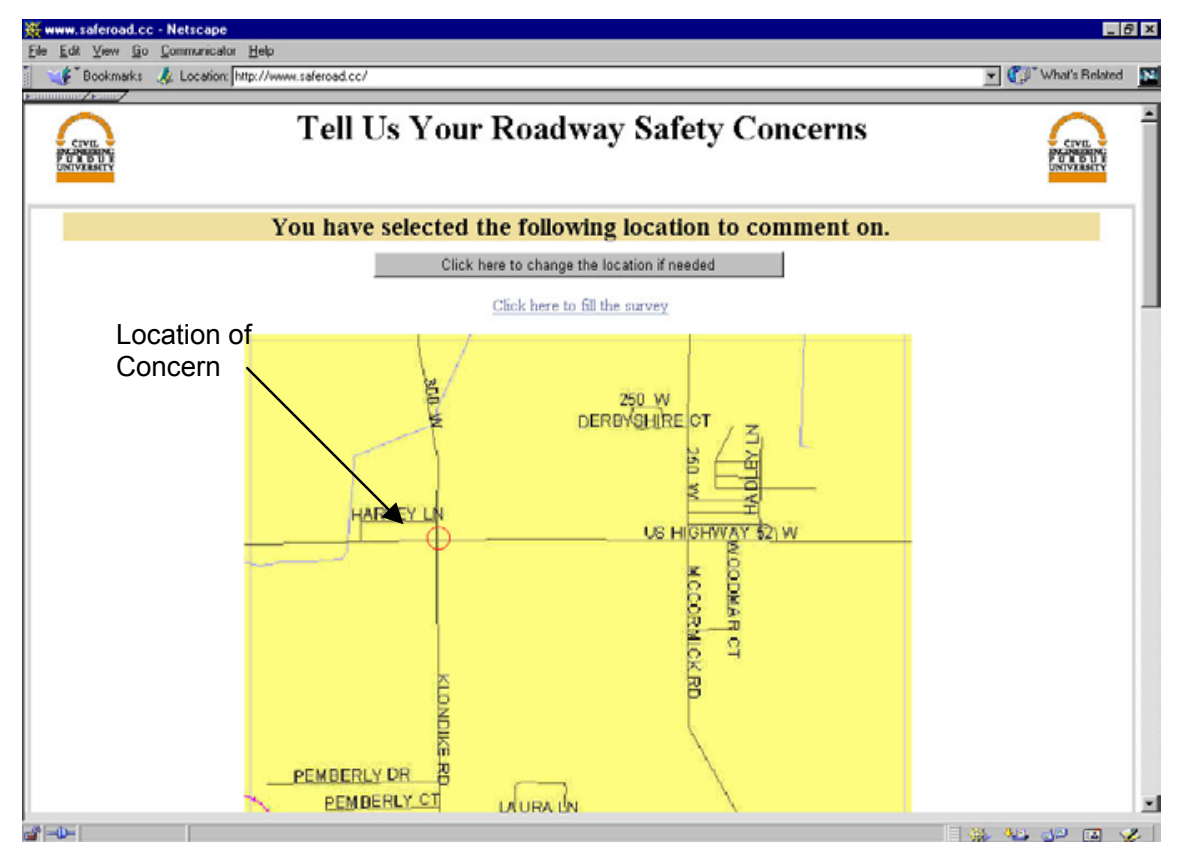

Figure 4.4. Final Map Zoom Level

The maps used in the prototype were obtained from a commercial source. The corner pixels of the images have associated GIS coordinates to allow conversion of the pixel-based locations selected by the respondents to their corresponding GIS coordinates. The GIS coordinates were obtained from the Tippecanoe County GPS office. An added benefit of providing GIS coordinates results from the ongoing implementation of a GIS-based accident reporting system in Indiana. It is hoped that when the entire accident database is linked to GIS coordinates, the crash analysis process will be streamlined, since the GIS coordinates can be matched and the survey responses can then be compared directly to accident statistics. This keeps the survey and website consistent with emerging technologies, so that the survey tool will not be rendered obsolete.

After selecting the location on the final zoom level, the location is marked and the user is given the option to re-select the location. Then, the questionnaire is presented to the respondent, allowing the respondent to fill out the survey. When finished, the respondent is given the option to select another location, and given a thank-you message. 


\subsection{Survey Database Design}

The survey database has been built in Microsoft Access, chosen for its relative ease-of-use and ability to generate formatted reports. An entry is initialized in Access as soon as a location is selected on the final static map. The entry is tagged with a set of GIS coordinates, a time and date stamp, and a unique record identification number. As soon as the survey is completed and the user selects the submission option, the responses inputted by the user are recorded in the database. Each survey question receives its own column in the database with a unique heading to identify it, allowing an agency to sort responses by any survey question. The table with responses reads from left to right, with Question 1 on the left to Question 9 on the right, followed by the GPS coordinate information and date and time stamp.

Another feature of the database is the automated removal of responses with zip codes outside the desired area of study. This not only restricts the responses to those within the desired area, but it also effectively removes most blank and incomplete responses with missing zip codes. The removal of responses has been accomplished by coding a short routine in Access, resulting in a new table without incomplete responses. The algorithm for this removal process is presented in Figure 4.5.

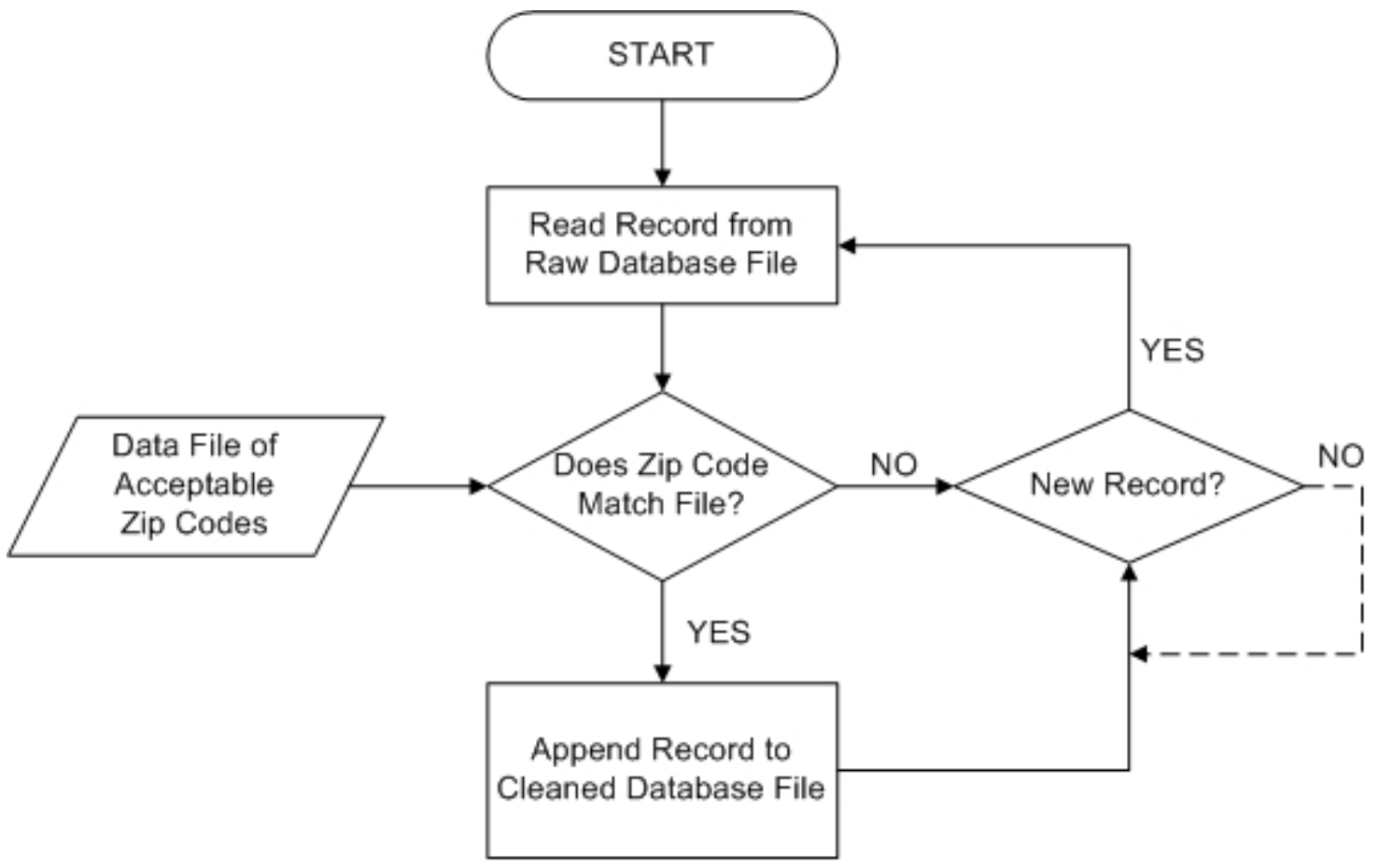

Figure 4.5. Database Cleaning Algorithm 
Raw data from the survey is read into the program, and the zip code response checked against a data file containing acceptable zip codes. This data file may contain any number of zip codes, from small localities to metropolitan areas with high commuter populations. In our prototype, the zip codes have been limited to Tippecanoe County. The removal of unacceptable zip codes also removes the blank responses created when a person initializes the website and does not input any information. If the response includes a zip code, then the record is appended to a "clean" responses file. This file can be used by an agency to generate reports using the database features. If no new record is found in the database, the program continues to run in the background, allowing for real-time updating of the database.

The prototype requires manual examination of the database to check for incomplete location information and for multiple responses. Nevertheless, the cleaning algorithm reduces significantly the amount of work needed to create a clean set of data. Another benefit of the database is the simplified manipulation of data. The use of Access or a similar database provides tools to sort out specific aspects of the database, as well as the ability to export the data into a spreadsheet for manual manipulation and statistical analysis. In addition, comments from the agency can be added into the database through the use of extra fields. In this way, the database can contain all pertinent information in one location for easy use by the agency.

\section{$\underline{4.4 \text { Website Implementation }}$}

The Internet tool has been implemented using a set of Active Server Pages (ASPs) with an SQL web server to handle the processing. The survey questionnaire was created using Microsoft FrontPage before conversion into the ASP format, and the survey responses were collected and stored through the use of a Microsoft Access database. The prototype design was implemented and maintained by Robert McCulloch and Michelle Leung at Purdue University. 


\section{CHAPTER 5. DATA COLLECTION}

Once the prototype survey tool was completed, the data collection process began. The data collection focused on highway users in the Tippecanoe County area, and data were collected over a period from July through December 2001. The following sections discuss the publicity campaign used to inform the public about the website, the scope of public response, and the statistics of incomplete responses.

\section{$\underline{5.1 \text { Publicizing the Website }}$}

The website was publicized in both print and electronic media to attract a wide representation of road users within Tippecanoe County. The first publicizing of the website occurred in the Purdue Exponent student and staff newspaper on July 18, 2001. Shortly thereafter, on July 23, a story about the website was broadcast on the local CBS television affiliate in Lafayette, WLFI. The second step in publicizing the website was an advertisement in the local newspaper, the Lafayette Journal and Courier, during the week of October 22-28, 2001. This ad is shown in Figure 5.1.

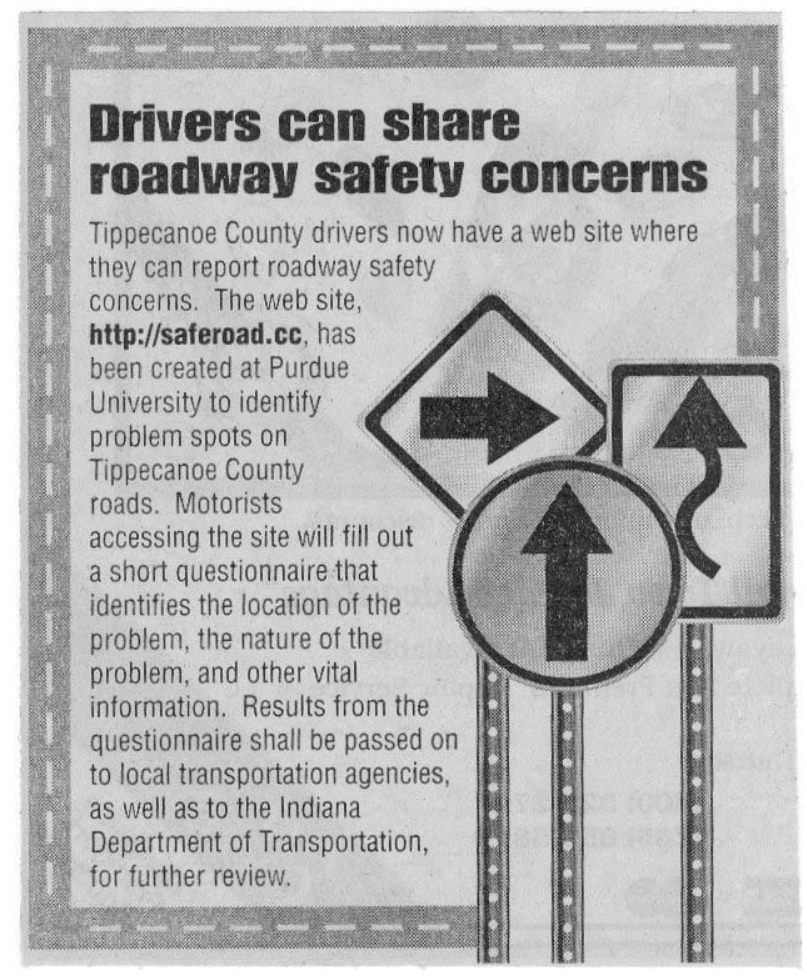

Figure 5.1. Newspaper Advertisement to Promote Website 
The ad was run on Monday, Wednesday, Saturday, and Sunday of that week. The advertisement corresponded with a story about the website printed on October 28 . The newspaper publicity was to be correlated more closely with the July publicity; however, a security problem with the website produced a significant delay in the publicity campaign.

\subsection{Distribution of Responses Over Time}

In five months of data collection, 146 responses were received. The distribution of responses over time is illustrated in Figure 5.2. As shown in the figure, the number of responses peaked sharply each time the website was called to the public's attention, and then the number of responses diminished quickly over time.

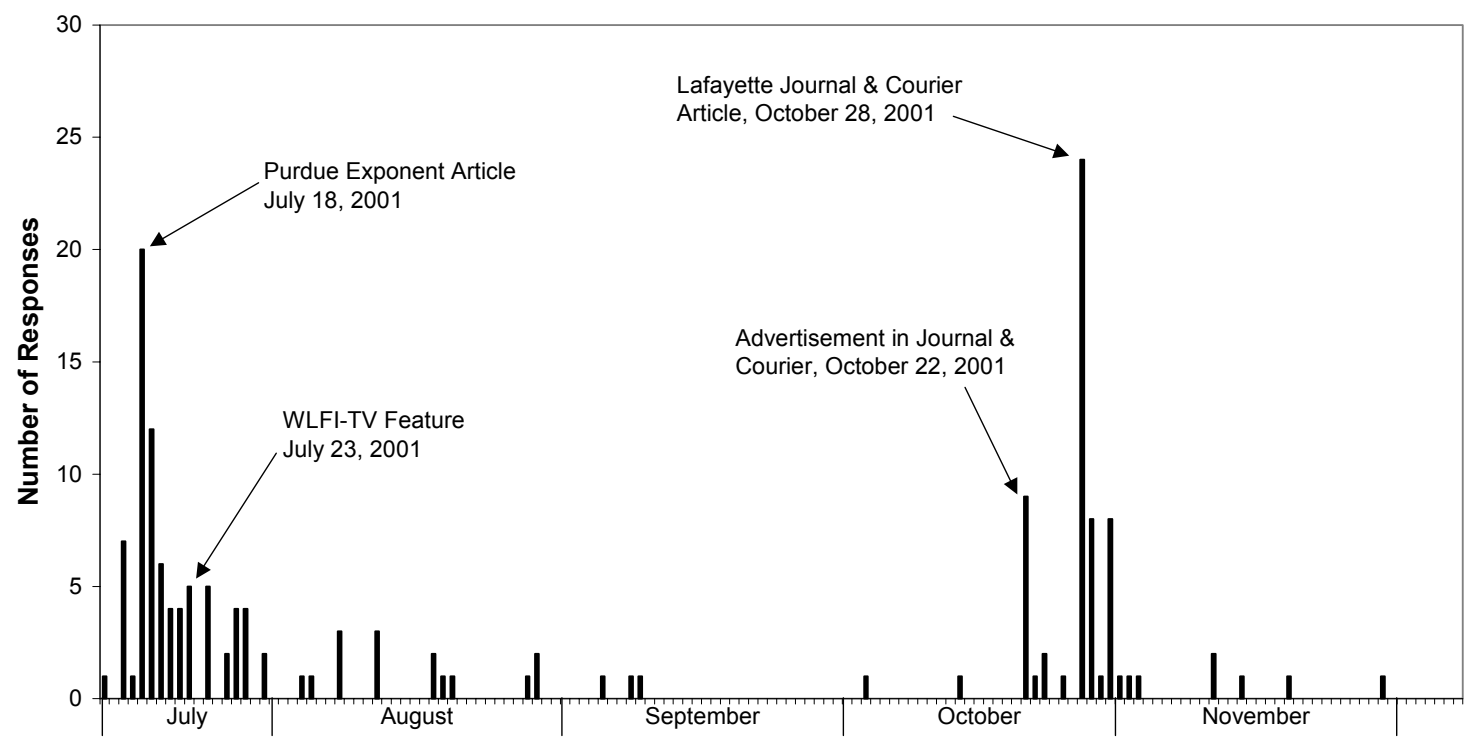

Figure 5.2. Distribution of Responses over Time

The trend in responses over time indicates that the website must be promoted at regular intervals to remind the public about the website and encourage its use. The figure also indicates that the media outlets are very powerful tools for informing large sections of the public about the website, as very sharp spikes in the number of responses are indicated on the days that the website was publicized in the local newspapers. The impact of television was not as dramatic, due to a website security problem at the time that it was publicized in the local television news on July 23. Without this security problem, it is possible that a similar spike would occur as per the newspaper publicity. From Figure 5.2 it can also be seen that it takes a considerable amount of time to 
collect a large number of responses, and without sustaining publicity, the number of responses would be quite low.

\section{$\underline{5.3 \text { Handling of Incomplete Responses }}$}

An important step in building the dataset for analysis was the removal of responses using the zip code criterion as discussed in Section 4.3. After applying the criterion, 146 responses were considered complete. Of the removed responses, three were test responses performed by officials of the Indiana Department of Transportation, five were incomplete responses with missing zip codes, and the rest were blank or testing and maintenance responses. The survey responses may be viewed in their entirety in Appendix B. Many of the rejected responses contained no information, which may have been a result of people visiting the website out of curiosity, or from maintenance and testing exercises. The responses that held some information were screened to make sure each response location could be identified, thus, if a person did not indicate a specific location in some form, that response was also rejected. This screening narrows the sample to only those locations that are easily identifiable for purposes of analysis and further investigation. The acceptable locations consisted of both intersections and locations between intersections. The last constraint on the responses used for analysis was that the zip codes provided by the respondent had to be within Tippecanoe County. This resulted in increased confidence in the data, since only local users were included. The zip code constraint also reduced the possibility of malicious users living outside Tippecanoe County. If the website is utilized in larger municipalities, care must be taken with the zip code criteria so as not to exclude commuting traffic. The resulting set of responses was thus similar to the responses that would be considered by a highway agency.

\section{$\underline{5.4 \text { Security and Stability Issues }}$}

Of primary importance throughout the data collection process was the security and stability of the website prototype. During the data collection process, one major security incident occurred, and many small stability problems occurred regarding software and server transitions.

The one major security incident occurred in July 2001 and involved a virus, which caused a server failure each time a person attempted to use the website. Based on expert opinions, it is believed that this virus entered the server due to security weaknesses in the Windows NT operating system, which was the original operating system used for the website. This virus 
caused frequent and sporadic days of downtime, possibly resulting in lost responses due to users visiting the website during the down period. Because of this virus, the website was transferred to the Windows 2000 operating system about a month after this incident. No other security incidents have occurred since the change in operating systems.

The minor stability issues were mainly caused by coding errors and errors created in December 2001 when the website was shifted from one server to another, resulting in broken connections between the website and the database. These stability issues were identified and corrected through the use of regular maintenance, as well as user feedback. Most of these small outages were corrected in the span of 24 to 36 hours.

In general, the website did not suffer many major technical problems, and if the proper maintenance measures are regularly performed, minor website outages can be minimized. Security problems can be avoided by isolating the website on a secure server and making sure the software packages used are free of security loopholes and resistant to malicious influences. 


\section{CHAPTER 6. EVALUATION OF THE SURVEY TOOL}

The following section evaluates the performance of the survey tool itself. This evaluation includes the demographic breakdown of the survey respondents, the summary of the responses, and the user feedback collected from the survey. This evaluation is hoped to help improve the prototype questionnaire to better address the preferences of the public and serve the purpose of the survey.

\section{$\underline{6.1 \text { Map Interface }}$}

The only concern with respect to the static map interface voiced by a few of the respondents was that the maps were outdated (the maps used were dated 1998). It indicates that frequent updating of a map interface is desirable in order to avoid confusion and to provide better accuracy. This limitation of the maps may explain why some of the reported locations could not be easily found.

\section{$\underline{6.2 \text { Survey Tool Accessibility }}$}

The two major demographic categories that were evaluated were the age and gender of the respondents. The age and gender information provided by the respondents were collected from the responses to the eighth question of the survey, which queries the users about personal information. All information given as a response to this question was voluntary.

\subsubsection{Age Distribution of Respondents}

The distribution of respondents by age is illustrated in Figure 6.1. As shown in this figure, the bulk of respondents fall into the 36-45 age range, however, there was a good distribution of responses among all of the age groups. 


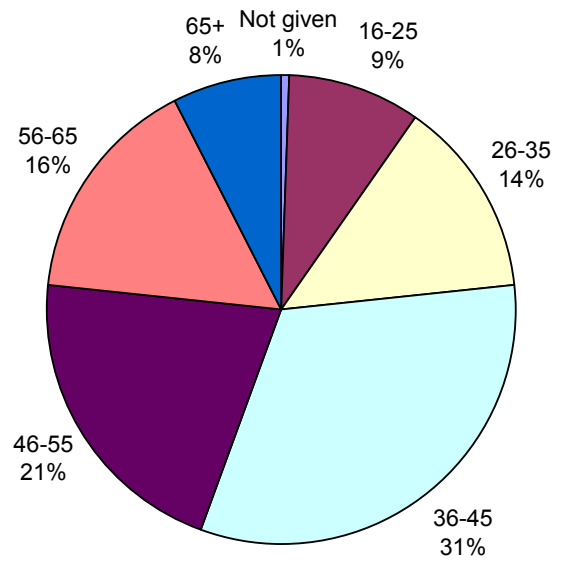

Figure 6.1. Distribution of Responses by Age Group

Since a wide variety of media were used in order to publicize the website, and common access to the Internet, it is believed that all age groups of drivers had sufficient notification and opportunity to learn about the website, thus, it can be assumed that no age groups were excluded from the opportunity to respond. The distribution of age groups from the respondents to the prototype survey does provide some evidence supporting the research performed by Cohn (1995), indicating that adolescents and adults do not perceive risk similarly. Nine percent of the respondents to the survey came from the 16-25 age group, which is low considering the large population of this age group within the county and the student population at Purdue University. This result may indicate that persons in this age group do not see high risk locations within the county highway network, and that persons in this age group were not concerned enough to utilize the prototype survey.

\subsubsection{Gender Distribution of Respondents}

The distribution of respondents by gender was found to be 60 percent male and 40 percent female. This result is slightly unusual in that there are more male respondents than female respondents. However, under the previous assumption that every respondent group has received sufficient opportunity to respond to the prototype survey based on the comprehensive publicity campaign, this is not a significant concern. 


\section{$\underline{6.3 \text { Evaluation of Survey Questions }}$}

The next section examines each survey question and how the respondents used each question. The purpose of this evaluation is to determine what response options need to be added or removed, or if there are entire questions that need to be added or removed. It is hoped that the prototype survey may be refined and adjusted using this information and user feedback in order to create a survey that best fits the needs and desires of the public as well as the implementing agency.

\subsubsection{Questions One and Two - Location of Concern}

The first and second questions of the survey describe the actual location of concern in terms of major street and nearest cross-street, and whether the concern lies at the intersection itself, or on an adjacent road section. Because complete location information was considered vital, responses without sufficient location information were removed from further analysis (Section 5.4). Among all 146 responses with Question 2 completed, nine responses failed to mention whether or not the location of concern was at the intersection of the two highways listed, or on an adjacent road section. This is a low number, which indicates that respondents were receptive to the question.

\subsubsection{Question Three - Basis of User Concern}

Question 3 of the prototype survey asked what the basis was for the concern of the survey user. The response options for this question are explained in Section 4.1.3, which discusses the development of the survey questions. In summary, the response options range from witnessing or being involved in a crash, second-hand knowledge from media or other sources, and observing near-misses and driver behavior. The summary of responses to this question is shown in Figure 6.2 . 


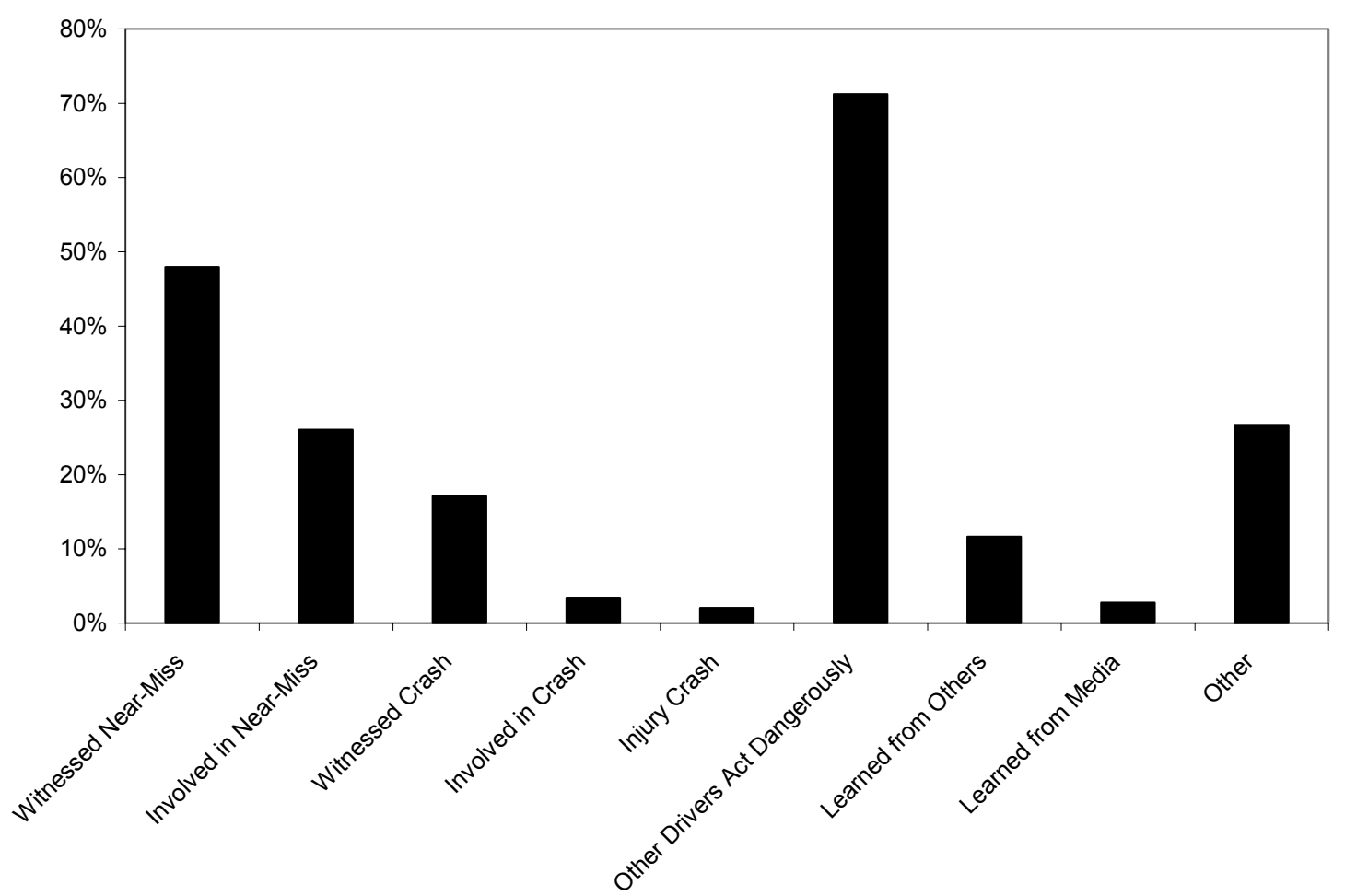

Figure 6.2. Basis of User Concern

The percentages shown in Figure 6.2 represent the fractions of the respondents who selected the options. The percentages do not sum up to $100 \%$ because respondents could give multiple responses. The number of respondents involved in injury crashes is very low, and this option may be covered by involvement in any crash option. The media information option also has a low response rate, and this option may be combined with the option involving learning about the location from other persons, in order to combine all of the sources of second-hand information into one response. All other options were well-utilized by the respondents, and thus further changes to this survey question beyond those mentioned previously are not necessary.

\subsubsection{Question Four - User-Reported Causes of Safety Problems}

In order to provide highway agencies with additional information about the reported highway locations, users were asked to express their opinion about possible causes of the dangerous situation. Nine different options were provided to cover potential causes of hazards, and a free response option was added to cover other causes. The results obtained from the user responses to this query are indicated in Figure 6.3. 


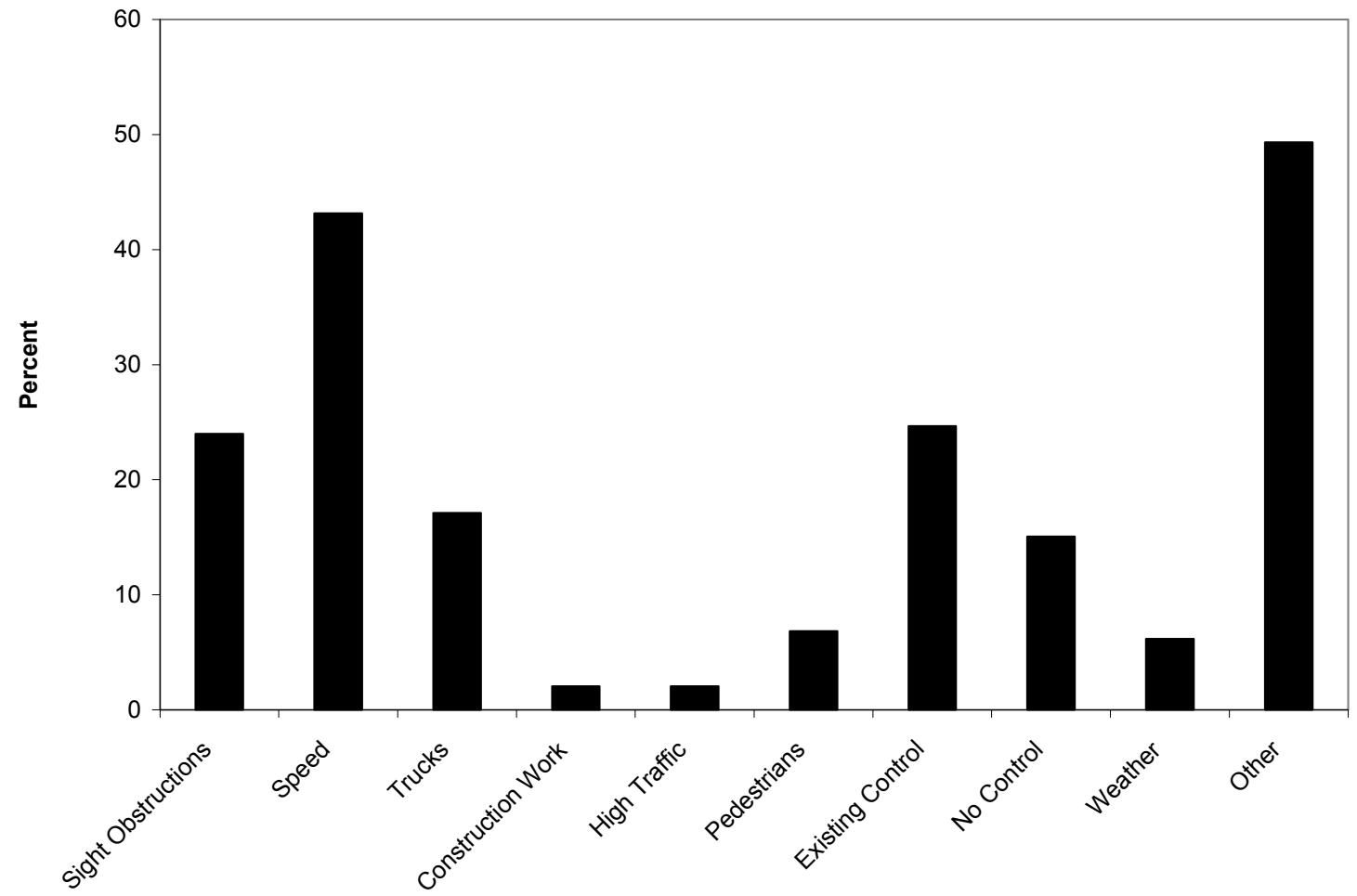

Figure 6.3. User-Reported Causes of Safety Problems

Question 4 is also multiple-choice with the possibility of selecting more than one option. The percentages in Figure 6.3 represent the fraction of the respondents who selected an option. As can be seen in the figure, construction work and traffic were the least used responses, as only two percent of respondents used each of these. The high-traffic options may be eliminated in the final prototype while the construction work option should be retained for its importance to agencies. Interestingly, the free-answer response was utilized by nearly 50 percent of the respondents. Some of these responses were clarifications or more description of one of the nine provided options, and some indicated other possible causes, such as turning movement problems and other design and maintenance considerations (snow removal, potholes, median barriers, etc.). From the free response option, the most frequently indicated problems that were not part of the original options were highway geometry, maintenance, turning vehicles, and lane markings. For the final survey prototype, these responses should be considered for addition. The free responses are very important in clarifying responses and providing additional options to a respondent. They should be examined carefully by the agency in order to maximize the amount of information gained from the survey. 


\subsubsection{Question Five - Frequency of Use of the Location}

Each respondent was asked to estimate how frequently he/she traveled through the reported location. The response options provided a wide range of frequencies from less than once per week up to more than twice per day. The summary of the data obtained from this survey question is shown in Figure 6.4.

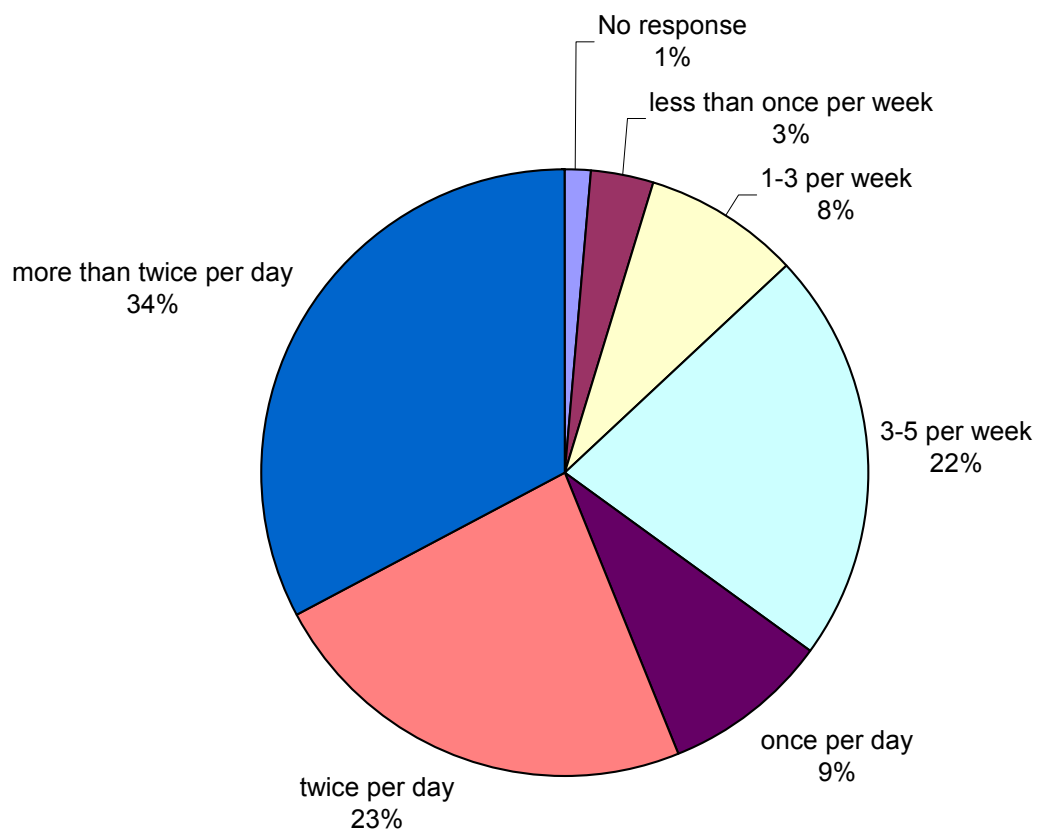

Figure 6.4. Frequency of Location Use

As shown in the figure, the number of non-respondents to this question is low, which indicates that the question was well received by the survey users. To eliminate the low-response options: once per day and 1-3 per week, an implementing agency may consider combining these two options with 3-5 per week and name the combined option as several times per week. Despite the very low number of responses, the option "less than once per week" should be retained to cover all possible cases. 


\subsubsection{Question Six - Time of Use}

The fifth question of the survey asked for the time when the respondent used the highway location in question. A graphical summary of results for this survey question is shown in Figure 6.5 .

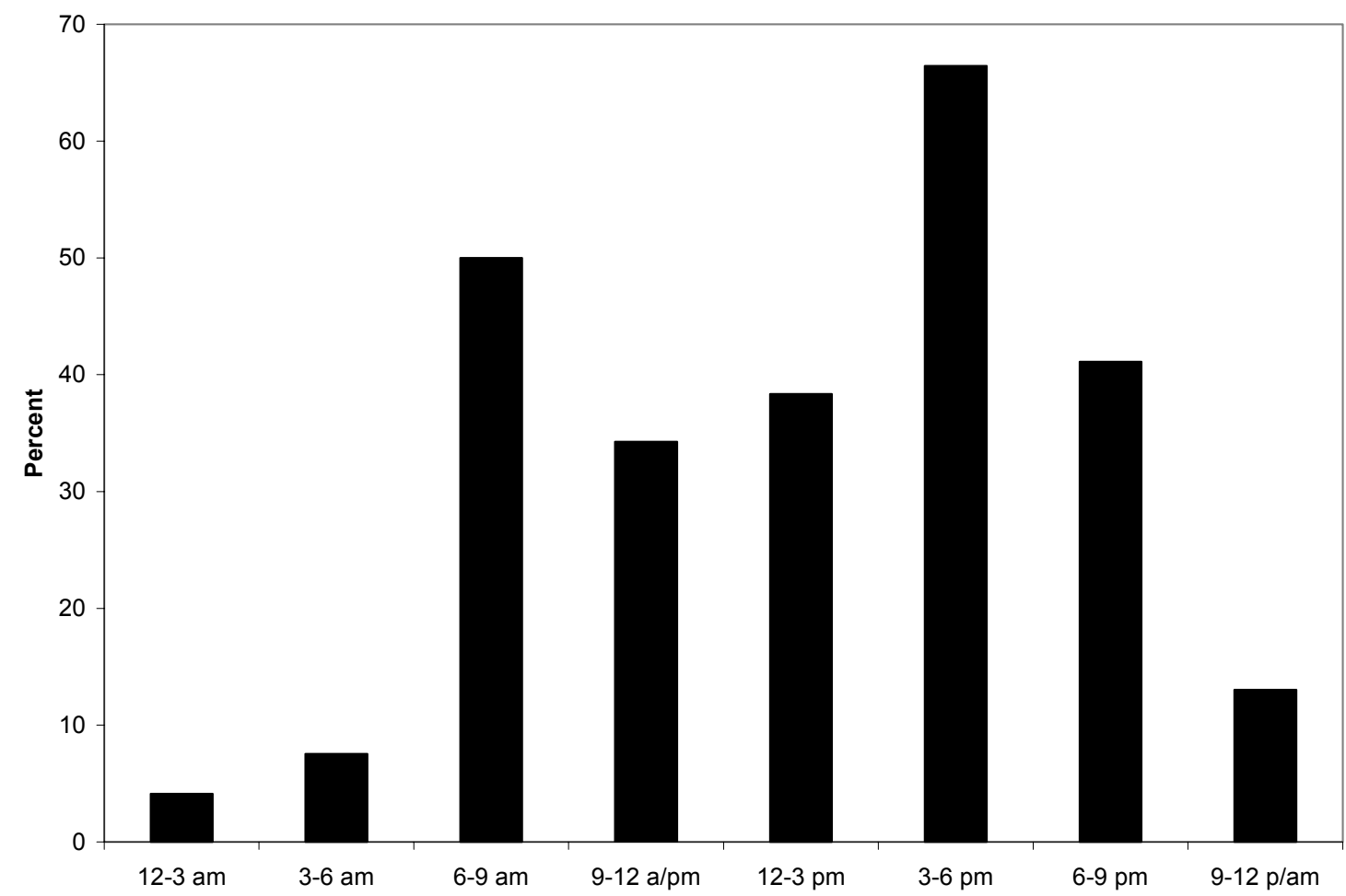

Figure 6.5. Time of Use

Multiple responses were again allowed for this question, since it is likely that highway users use the same location at different times during the day, i.e., commuting. The percentages in the figure represent the percentage of the respondents. The graph indicates that all of the time periods experienced some number of responses, which indicates full representation of all time periods. The very late night and early morning responses only indicate a small number of responses, but this is less an indication of respondents not using the options as it is a verification of normal travel patterns. Similarity of this pattern to the daily pattern of traffic volumes increases confidence towards the survey results. 


\subsubsection{Question Seven - Willingness for Spending Extra Travel Time}

The level of concern of the respondent about the reported location was measured with the amount of extra travel time the respondent was willing to spend in order to avoid the location. As mentioned in the question development portion of this report (Section 4.1.3), the travel time gradations provided in the survey were selected in respect to the size of Tippecanoe County. Other travel time gradations should be considered based on the size of the analysis area, urban/rural characteristics of the area, and general volume of traffic. For example, for a large metropolitan area such as Indianapolis, higher maximum travel times might be found appropriate. The compiled results of the travel times provided by the survey respondents for Tippecanoe County are shown in Figure 6.6.

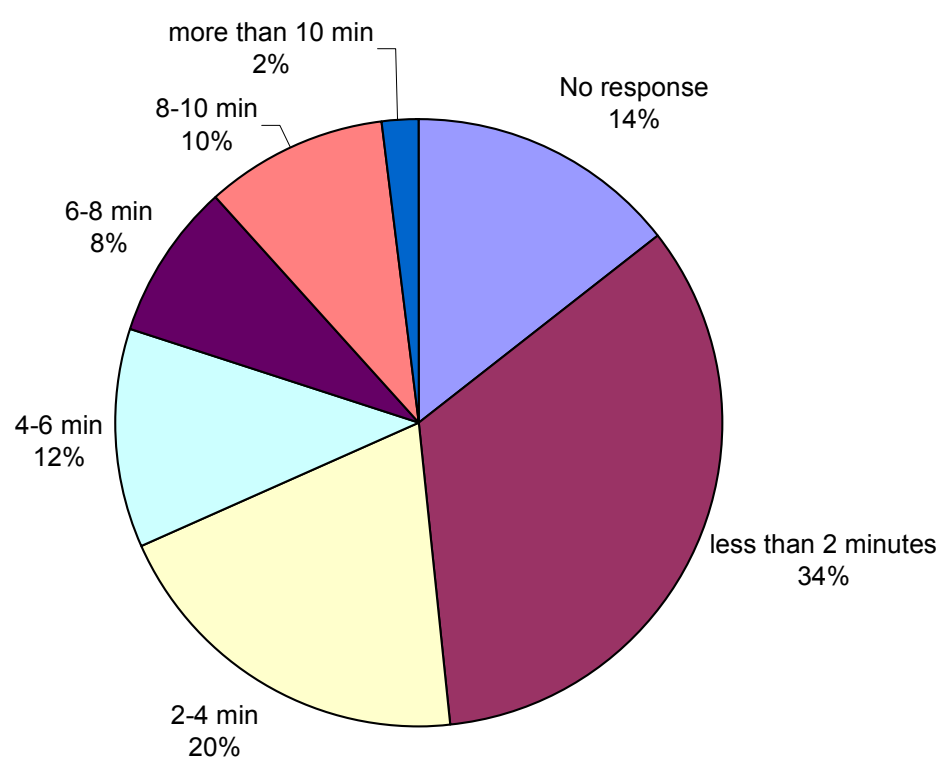

Figure 6.6. Respondents' Acceptable Extra Travel Time

Each range of travel time was indicated by a considerable number of respondents, as indicated in Figure 6.6, except the "more than 10 minutes." This option could be merged with the 8-10 minute travel time range, however, this response provides a suitable maximum value for the travel time response scale, and thus a change is not recommended. The results confirm the appropriateness of the travel time gradation selected for Tippecanoe County. If a large number of responses of more than 10 minutes had existed, it would indicate a need to add ranges for longer travel times. 


\subsubsection{Question Eight - Demographic Information}

The age and gender information provided by this survey question have already been discussed in Section 6.2, so the focus of this section is on the zip code and email responses to this survey question. The zip code responses may be used by the agency to determine whether or not the bulk of respondents are commuters or local residents, and to eliminate incomplete or frivolous responses. The email address can be used to contact individuals to obtain further information, or to make sure a person is not abusing the survey by responding multiple times for the same location. Only one respondent responded multiple times for the same location in the course of this research. The email response was optional and the rate was 47 percent. The implementing agency would be well served by including some form of contact information question similar to Question 8, since the information not only increases confidence in the response, but also provides a means of contacting the individual.

\section{$\underline{6.4 \text { User Feedback }}$}

The final section of the survey involved user feedback to the survey tool. Six questions were asked about the quality of the survey (all under the Question Nine heading), with five of these questions having optional answers of yes, no, or indifferent, and the sixth being a comment box. The questions asked about the convenience of the interactive map, the user-friendliness and readability of the survey, and the sufficiency of the questions and response options. The comment box allowed the user to input any additional information or comment. For the five multiple-choice questions, the results are summarized in Table 6.1.

Table 6.1. User Feedback on Survey Design

\begin{tabular}{|l|r|r|r|r|r|}
\hline Category & $\begin{array}{c}\text { Convenience } \\
\text { of Interactive } \\
\text { Map }\end{array}$ & $\begin{array}{c}\text { User- } \\
\text { Friendliness }\end{array}$ & Readability & $\begin{array}{c}\text { Sufficiency of } \\
\text { Questions }\end{array}$ & $\begin{array}{c}\text { Response } \\
\text { Options }\end{array}$ \\
\hline Yes & $82.3 \%$ & $80.3 \%$ & $91.2 \%$ & $52.4 \%$ & $53.7 \%$ \\
\hline No & $9.5 \%$ & $3.4 \%$ & $0.7 \%$ & $17.0 \%$ & $19.1 \%$ \\
\hline Indifferent & $8.2 \%$ & $16.3 \%$ & $8.2 \%$ & $31.3 \%$ & $27.2 \%$ \\
\hline
\end{tabular}

As seen in Table 6.1, the feedback was generally positive. The users gave the website high ratings in the convenience of the interactive map, the user-friendliness of the survey, and the readability of the survey. The users were not as positive with regard to the sufficiency of the 
provided questions and the response options. It is quite possible that some questions and response items can be added to the survey in order to improve these aspects of the survey (as discussed previously). However, there are limits as to what could be added, as the survey would become cumbersome if it were too inclusive.

Examining the user responses to the comment box, it was found that about 70 percent of respondents use the comment box to clarify their concerns and give specific details. Many of the responses are elaborated and point to specific problems, such as signal timing for individual lane movements, or specific trees that block sight lines. These responses should be examined thoroughly by the investigating agency in order to gain potentially useful information.

Approximately 7 percent of the responses were used for additional suggestions about other aspects of the survey tool. The questions and responses addressing safety issues are further discussed in Chapter 7. 


\section{CHAPTER 7. SAFETY INFORMATION RECEIVED}

After examining the response rates for each question, it was desirable to evaluate the information that had been received and its significance in terms of highway safety. This chapter evaluates selected survey questions from the safety perspective; beginning with the sources of knowledge about each location, the causes of the safety problems at the reported locations, and the travel time responses. The chapter concludes with a summary of locations indicated by the respondents. Through this evaluation, a general public perception of safety on Tippecanoe County highways is learned.

\subsection{Basis for Opinion}

One of the more important pieces of data collected from the survey is the basis of the respondent's opinion that the location is unsafe. It is more desirable if the respondent had firsthand experience of problems at a location and was not reliant on second-hand information such as media reports. This helps to avoid bias due to highly publicized accidents or similar situations, and focuses the reporting agency on possible unseen safety problems. As indicated in Figure 6.2 in Section 6.3.2, only about 14 percent of respondents supported their opinion about the location with second-hand information. Considering that the question allowed multiple responses, and no response indicated a second-hand source alone, this is a remarkably low percentage. About 22 percent of respondents were involved in or witnessed a crash. It indicates that 78 percent of the reports obtained from the survey contain new information not included in the crash records. This result is encouraging and it indicates that the survey is a promising source of safety information.

\section{$\underline{7.2 \text { User-Reported Causes of Safety Problems }}$}

As mentioned to in Section 6.3.3, one of the objectives of gathering user opinions about the cause of a safety problem at a location is to provide the agency with information that may not be present in crash records. In addition, this information may prompt the highway agency about potential causes of hazards and help focus on the most promising details when examining and studying a location. The summary of the responses is shown in Table 7.1. A graphical representation of this data, excluding the information obtained from the free-response option, is shown as Figure 6.3 in Section 6.3.3 of this paper. The data in Table 7.1 are sorted from highest percentage of responses to lowest percentage of responses. 
Table 7.1. User-Reported Causes of Safety Problems

\begin{tabular}{|l|r|r|}
\hline \multicolumn{1}{|c|}{ Cause of Problem } & Responses & $\begin{array}{r}\text { Percentage of } \\
\text { Respondents }\end{array}$ \\
\hline Speed & 64 & 44 \\
\hline Traffic Control [Existing or Lack of] & 58 & 40 \\
\hline Sight Obstructions & 35 & 24 \\
\hline Trucks & 25 & 17 \\
\hline Highway Geometry & 14 & 10 \\
\hline Pedestrians & 10 & 7 \\
\hline Weather & 9 & 6 \\
\hline Maintenance & 7 & 5 \\
\hline Turning Vehicles & 7 & 5 \\
\hline Driver Behavior & 7 & 5 \\
\hline Lane Markings & 4 & 3 \\
\hline Construction Work & 3 & 2 \\
\hline High Traffic & 3 & 2 \\
\hline Enforcement & 3 & 2 \\
\hline Buses & 1 & 1 \\
\hline Trains & 1 & 1 \\
\hline
\end{tabular}

As indicated in the table, speed was by far the most cited cause of concern for highway users, followed by traffic control and sight obstructions. Traffic control problems in particular seem to be a significant concern, since a total of 58 respondents indicated either a lack of traffic control or problems with existing traffic control as their cause for concern. The category of highway geometry encompassed all concerns about geometric features such as turn lanes, medians, and other concerns involving the physical design of the facility. These concerns, as well as others such as maintenance and driver behavior, were gathered from the free response option of this particular survey question. With this survey outcome, it appears that speed, traffic control, sight obstructions, trucks, and highway geometry are good starting points for agency officials seeking to investigate locations within the county. As such, these results are localized to the area of study, in this case, Tippecanoe County, and may not apply to other locations. The free-response option provided more detailed information for many of these responses, such as particular trees that are sight obstructions, and particular movements for signal timing concerns under the existing traffic control option. This detail is only available to the agency by examining the freeresponse options carefully, and could provide agencies with a quick pinpointing of potential problems at a location, which could save time in investigation and remediation. Thus, the prototype survey has the potential to provide the agency with large amounts of safety hints about a location. It is therefore recommended that the question about user-perceived causes of the safety problem be included in a future questionnaire. 


\section{$\underline{\text { 7.3 Travel Time Responses }}$}

The extra travel time acceptable by the respondent to avoid the hazard was used as an indicator of the level of perceived risk. In other words, the extra travel time provides a measure to quantify the magnitude of concern of respondents. The distribution of the extra travel time is shown in Figure 6.6 of Section 6.3.6. It appears that most respondents quantify their concerns in the range of zero to four minutes of travel time. Therefore, it can be inferred that while motorists are concerned, they may not be concerned enough to expend large amounts of travel time. On the other hand, there are areas of major concern to highway users as well, since nearly a third of respondents indicated a travel time of four or more minutes. The pattern of responses indicates a moderate and not overblown concern about highway locations in Tippecanoe County.

\section{$\underline{7.4 \text { Locations of Concern }}$}

The 146 respondents have reported 95 different highway locations in Tippecanoe County, both intersections and highway sections. Table 7.2 shows the 25 locations with two or more responses, and the total extra travel times. The entire set of 95 locations may be viewed in Table C.1 in Appendix C. The locations are listed in descending order by number of responses. Based on the number of concerns provided by respondents to the prototype survey, it appears that the intersection of U.S. 52, Creasy Lane, and Brady Lane is the location that respondents to the survey considered to be the most hazardous in Tippecanoe County. The extra travel time for the set of 95 locations is highly variable. The variation is caused by differences in individual opinion and the risk tolerance of each respondent. An example is the location of Concord Rd. and Brady Ln., which had a total travel time of 17 minutes, reported by five respondents (average 3.4 minutes), whereas the location of Stadium Dr. and Robinson St. had a similar total travel time of 16 minutes, but reported by only 2 respondents (average of 8.0 minutes). The variability of travel times between respondents for the same location will be examined in Chapter 8, where the quality of the information is evaluated. 
Table 7.2. Top 25 Locations in Terms of Number of Responses

\begin{tabular}{|r|l|l|r|r|}
\hline Rank & \multicolumn{1}{|c|}{ Route 1 } & \multicolumn{1}{|c|}{ Route 2 } & Responses & Total Time \\
\hline 1 & US 52 & Brady Ln./Creasy Ln. & 7 & 45 \\
\hline 2 & US 52 & SR 26 & 6 & 26 \\
\hline 3 & SR 26 & Creasy Ln. & 6 & 26 \\
\hline 4 & Concord Rd. & Brady Ln. & 5 & 17 \\
\hline 5 & SR 25 (Teal Rd.) & Concord Rd. & 5 & 9 \\
\hline 6 & I-65 & SR 43 & 3 & 15 \\
\hline 7 & US 52 \& SR 25 & Greenbush St. & 3 & 9 \\
\hline 8 & SR 126 (Cherry Ln.) & US 231 (Northwestern Ave.) & 3 & 8 \\
\hline 9 & US 52 \& 231 & McCormick Rd. & 3 & 7 \\
\hline 10 & US 231 (Northwestern Ave.) & Stadium Dr. & 3 & 4 \\
\hline 11 & Stadium Dr. & Robinson St. & 2 & 16 \\
\hline 12 & US 52 \& SR 25 & Duncan Rd. & 2 & 14 \\
\hline 13 & US 231 (Northwestern Ave.) & Lindberg Rd. & 2 & 12 \\
\hline 14 & 18 th St. & Central St. & 2 & 12 \\
\hline 15 & DeHart St. & Robinson St. & 2 & 8 \\
\hline 16 & SR 43 & Burnett Rd. & 2 & 8 \\
\hline 17 & US 52 \& 231 & Klondike Rd. & 2 & 7 \\
\hline 18 & SR 25 & Beck Ln. & 2 & 6 \\
\hline 19 & SR 43 (South River Rd.) & Harrison Br. (US 231) & 2 & 6 \\
\hline 20 & SR 26 (South/Columbia) & Main St & 2 & 6 \\
\hline 21 & US 52 \& 231 & Morehouse Rd. & 2 & 3 \\
\hline 22 & Sharon Dr. & Soldier's Home Rd. & 2 & 2 \\
\hline 23 & SR 25 (Teal Rd.) & 22nd St/Earl Ave. & 2 & 2 \\
\hline 24 & US 52 \& SR 25 & SR 38 E (Main St.) & 2 & 2 \\
\hline 25 & McCarty Ln. & CR 500 E & 2 & 2 \\
\hline
\end{tabular}

The number of responses may represent the magnitude of hazard at each location, and may be reinforced through the amount of travel time indicated by users. The postulate that more concerns and/or more total travel time indicate a higher magnitude of hazard will be tested in Chapter 8. 


\section{CHAPTER 8. EVALUATION OF INFORMATION RECEIVED}

After examining the responses that have been received, it is necessary to evaluate the quality of the information in respect to hazardous locations. The first test of the quality of information will check if the locations reported by highway users are more hazardous than locations not reported. Then, more thorough tests will be performed to examine the effectiveness of using the survey responses to pinpoint the hazardous locations.

In order to evaluate the information, a number of randomly selected state-maintained intersections (no road sections) were examined. A random sample of 360 locations was selected through the use of an integrated database developed by Weiss (1996), which combines the Indiana state road inventory data and the Indiana State Police (ISP) crash data. The initially selected locations were reduced to 26 locations by removing locations that did not have unique location identification numbers in the ISP crash database, and locations that had undergone improvements in 1997-2001 that could affect safety.

All survey responses referring to the same location included in the sample were grouped together. The detained clusters of responses were used in the information evaluation testing. In the presented study, an expected crash frequency has been selected as a measure of safety. The total number of crashes reported from 1997-1999 at the sample locations was used as crash frequency estimates. Use of crash rates was also considered. The lack of volume data for some locations did not allow for using this measure of safety. The sample of intersections, with their corresponding three-year crash counts and travel time information from the survey responses, may be viewed in Appendix D.

\subsection{Are Reported Locations Truly More Hazardous?}

The first evaluation test is to determine if the locations with responses are significantly more hazardous than those locations without responses. This evaluation is performed for both the number of responses for each location and the total reported travel time for each location.

Checking both measures helps determine which is more effective in measuring the hazardousness of a location. 


\subsubsection{Binomial Test for Number of Responses}

In order to evaluate the number of responses as a measure of hazard, the locations were separated into six groups according to the number of responses received for each location. Table 8.1 shows the characteristics of these six groups.

Table 8.1. Groups of Locations Based on Number of Responses per Location

\begin{tabular}{|c|r|r|r|r|}
\hline Group & $\begin{array}{c}\text { Number of } \\
\text { Responses Per } \\
\text { Location }\end{array}$ & $\begin{array}{c}\text { Number of } \\
\text { Locations }\end{array}$ & $\begin{array}{c}\text { Crash } \\
\text { Total }\end{array}$ & $\begin{array}{c}\text { Avg. Number } \\
\text { of Crashes }\end{array}$ \\
\hline A & 6 & 2 & 124 & 62.0 \\
\hline B & 5 & 1 & 69 & 69.0 \\
\hline C & 3 & 5 & 128 & 25.6 \\
\hline D & 2 & 6 & 110 & 18.3 \\
\hline E & 1 & 17 & 267 & 15.7 \\
\hline F & 0 & 230 & 1063 & 4.6 \\
\hline
\end{tabular}

Based on the average number of crashes per location, it can be claimed that Groups A and B are more hazardous than all other groups, Group E is more hazardous than Group F, and so on. The table generally indicates that locations with responses tend to have a higher average number of crashes and are thus more hazardous, but is the difference significant statistically?

In order to check this result, a statistical test using the binomial distribution will be performed pairwise to check the significance of the difference between each of the groups. In this case, the null hypothesis is that two groups being tested are equally hazardous, or in other words, there is no difference between the two groups in the expected number of crashes per location. A binomial distribution will be used to calculate the likelihood of difference between the two tested groups longer than observed in the sample. This likelihood will be considered a significance value of the difference. If the significance value is low enough, the null hypothesis may be rejected, and it can be said that the group with the higher mean (always the first group in the test) tends to be more hazardous than the second group.

As an example, let us consider a comparison between Group D and Group E. The cumulative binomial distribution is used so that significance values may be determined. This distribution has the general form described in Equation 1. 


$$
B(x ; n, p)=\sum_{y=0}^{x}\left(\begin{array}{l}
n \\
y
\end{array}\right) p^{y}(1-p)^{n-y}
$$

In Equation 1, $\mathrm{x}$ is the total number of crashes in the first group of locations minus one, $\mathrm{n}$ is the total number of crashes in both groups of locations, and $p$ is the probability of success consistent with the null hypothesis. It is the likelihood that a crash happens in the first group of locations assuming that all locations in both groups are equally hazardous. In this example; $x=110-1=$ $109, n=110+267=377$, and $p=6 /(6+17)=0.261$. When these numbers are substituted into Equation 1, then the result is:

$$
\mathrm{B}(109|377| 0.261)=\sum_{\mathrm{y}=0}^{109}\left(\begin{array}{l}
377 \\
109
\end{array}\right) 0.261^{\mathrm{y}} \cdot(1-0.261)^{377-\mathrm{y}}
$$

When this expression is evaluated, the result is 0.903530 . This is the area under the curve of the cumulative binomial distribution for the parameters in this example. The significance value is simply the cumulative binomial value subtracted from 1 , or in this case, 0.096470 . Thus, it can be concluded that the null hypothesis can be rejected at the $10 \%$ significance level, and Group D tends to have more hazardous locations than Group E. This test was repeated in comparing all of the evaluation groups, and the results are shown in Table 8.2 as a matrix of significance values.

Table 8.2. Significance Matrix for Number of Responses

\begin{tabular}{|c|c|c|c|c|c|c|}
\cline { 2 - 7 } \multicolumn{1}{c|}{} & \multicolumn{5}{c|}{ Group } \\
\hline Group & A & B & C & D & E & F \\
\hline A & & 0.785835 & 0.000000 & 0.000000 & 0.000000 & 0.000000 \\
\hline B & & & 0.000000 & 0.000000 & 0.000000 & 0.000000 \\
\hline C & & & & 0.006053 & 0.000007 & 0.000000 \\
\hline D & & & & & 0.096470 & 0.000000 \\
\hline E & & & & & & 0.000000 \\
\hline F & & & & & & \\
\hline
\end{tabular}

Table 8.2 shows that all but one of the tests indicates differences between groups significant at the $10 \%$ level. The one exception is groups $A$ and $B$. Since the average number of crashes in group $A$ is lower than the average number of crashes in Group $B$, this is not a surprising result. This exception could be due to the variability in crash occurrence and and risk perception among 
the respondents. A larger number of locations with five and six responses would be desirable to determine if this is the case. In any case, the results shown in the significance matrix support the conclusion that locations with responses tend to be more hazardous than those without. In addition, the matrix shows that the level of hazard tends to increase as the number of responses increase.

\subsubsection{Binomial Test for Travel Time Responses}

It is reasonable to check if extra travel times indicated by respondents are more effective than the number of responses in measuring highway hazards. Although the travel time question is supposed to serve this purpose, it is quite possible that the travel time responses do not add any additional information beyond what is known based on the number of responses. In order to answer this question, the travel time responses for each location were added together, and the locations were clustered into five groups based on the total travel time given by respondents.

Table 8.3 shows the sorted groups in five-minute increments of travel time, as well as their crash statistics.

Table 8.3. Groups of Locations Based on Total Travel Time per Location

\begin{tabular}{|c|r|r|r|r|}
\hline Group & $\begin{array}{c}\text { Total Travel } \\
\text { Time Per } \\
\text { Location }\end{array}$ & $\begin{array}{c}\text { Number of } \\
\text { Locations }\end{array}$ & $\begin{array}{c}\text { Total } \\
\text { Crashes }\end{array}$ & $\begin{array}{c}\text { Avg. Number of } \\
\text { Crashes Per } \\
\text { Location }\end{array}$ \\
\hline A & 20 or More & 2 & 124 & 62.0 \\
\hline B & $15-20$ & 1 & 24 & 24.0 \\
\hline C & $10-15$ & 2 & 33 & 16.5 \\
\hline D & $5-10$ & 9 & 191 & 21.2 \\
\hline E & $0-5$ & 247 & 1337 & 5.4 \\
\hline
\end{tabular}

The results in Table 8.3 indicate that use of the total travel times as determinants of hazardousness of locations is not as effective as the number of responses. For instance, the average number of crashes per location in Group $C$ is not as large as the average number of crashes in Group D. To reinforce this result, binomial testing was performed on each of the groups in a similar manner as in Section 8.1.1. The results of the binomial testing are shown in the significance matrix in Table 8.4. 
Table 8.4. Significance Matrix Based on Travel Time

\begin{tabular}{|c|c|c|c|c|c|}
\cline { 2 - 6 } \multicolumn{1}{c|}{} & \multicolumn{5}{c|}{ Group } \\
\hline Group & A & B & C & D & E \\
\hline A & & 0.000002 & 0.000000 & 0.000000 & 0.000000 \\
\hline B & & & 0.104397 & 0.316134 & 0.000000 \\
\hline C & & & & 0.926047 & 0.000000 \\
\hline D & & & & & 0.000000 \\
\hline E & & & & & \\
\hline
\end{tabular}

As indicated in Table 8.4, the difference in hazard between locations based on travel time is not as evident compared to the difference in hazard between locations based on number of responses. With the exception of locations with very high crash totals, the differences between location groups are not very significant. The test results confirm that the travel time question is not necessary in an implemented version of the questionnaire. Further analysis presented in this report will use numbers of responses only.

\subsection{Evaluation of Survey-Based Detection of Hazardous Locations}

With the binomial test results indicating that locations with responses are more hazardous than those without, it is important to check whether the responses themselves can be used as a surrogate for crash data; that is, can responses be the sole basis for identifying hazardous locations? To answer this question, a detection task was performed on the sample of intersections and the detection rates and false detection rates examined. In order to accurately describe this detection analysis process, a few parameters must first be defined.

\subsubsection{Definition of Detection Parameters}

The first detection parameter of note is the detection rate. The detection rate is defined as the likelihood that a hazardous location is detected with the survey tool. This rate is computed as the proportion of hazardous locations in the sample indicated by survey responses to all the hazardous locations. A location is considered hazardous if the number of recorded crashes during a certain period (here, three years) equals or exceeds a threshold number. This detection parameter provides information as to whether or not the responses themselves are efficient in detecting hazardous locations. If the proportion is high enough, then it is justified to conclude that the survey tool can be used as a surrogate for crashes if crash data are not available. 
The second detection parameter is the false detection rate. The false detection rate is defined as the likelihood that a non-hazardous location is detected with the survey tool. Similarly to the detection rate, the false detection rate is calculated as the proportion of non-hazardous locations in the sample indicated by survey respondents as hazardous. The parameter is a measure of the propensity of the public to have a false perception about risk at a location. Together with the detection rate, it provides an evaluation means of the reliability of motorist feedback.

The final detection parameter evaluated in this study is what shall be termed efficiency rate. The efficiency rate is represented by the proportion of hazardous locations reported by respondents to the total number of locations indicated by respondents. It is called the efficiency rate because it represents the likelihood that an agency would not be wasting resources by responding to the information provided by a survey respondent. This makes the efficiency rate a very important measure of the usefulness of motorist feedback to the agency.

\subsubsection{Results of Detection Analysis}

Figure 8.1 shows the plotted detection and false detection rates for a variety of motorist response and crash thresholds. The crash threshold is the number of crashes over three years for which any locations with that number of crashes or greater would be considered hazardous. The six curves represent conditions under which one, two, or three responses would be required for the agency to take action at the location. As an example, if the crash threshold is taken as 15 crashes over three years, and any response is reacted upon by the agency, then the detection rate is approximately 45 percent, and the false detection rate is approximately 6 percent.

Figure 8.2 shows the efficiency rate for a variety of motorist response and crash thresholds. The crash threshold is again the number of crashes over three years for which any locations with that number of crashes or greater would be considered hazardous. The three curves in the figure again represent conditions under which one, two, or three responses would be required to take action at a location. An example using the efficiency rate would be that if the crash threshold is 15 crashes over three years, then the efficiency rate is 55 percent for reaction to any response, 85 percent for reaction to two or more responses, and 95 percent for reaction to three or more responses. 


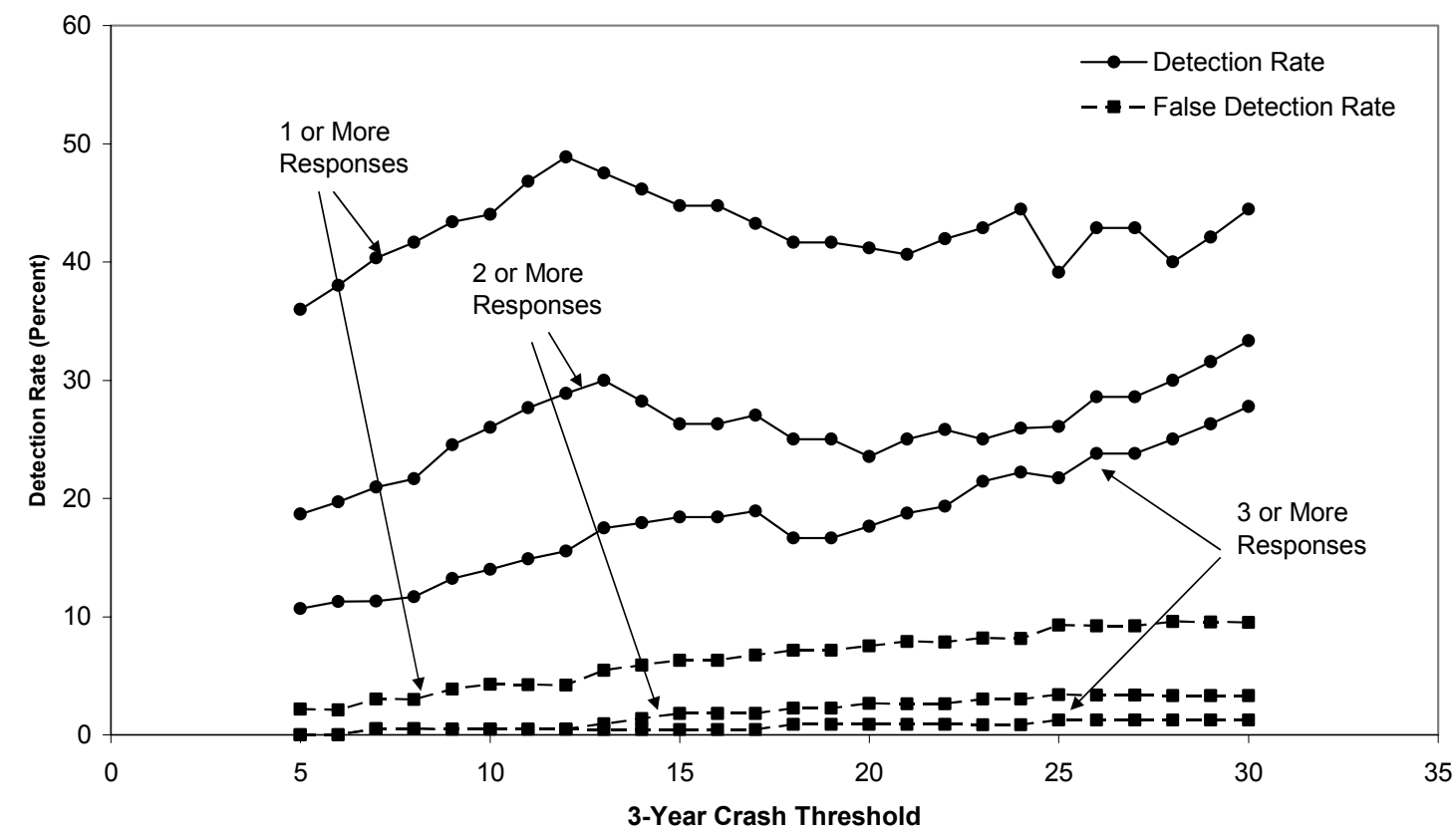

Figure 8.1. Detection Rate Curves

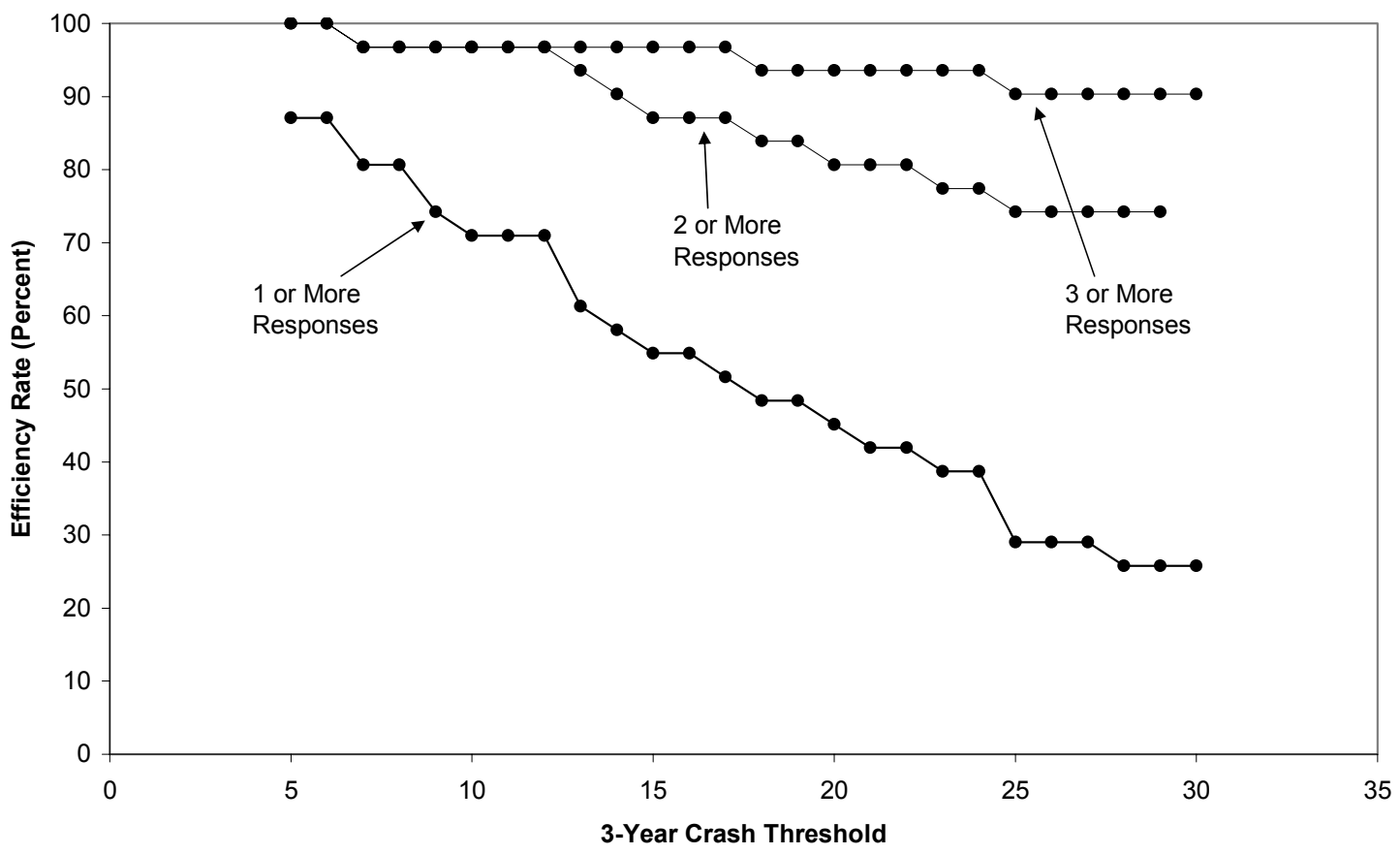

Figure 8.2. Efficiency Rate Curves 
It should be noted that these curves are constructed using the sample of 260 state-maintained locations developed earlier, with 31 of these locations being identified as hazardous by the respondents to the prototype Internet survey. Looking at Figure 8.1, it is apparent that, while the survey respondents are providing good information, with detection rates around 40 to 45 percent and false detection rates generally less than 10 percent, the results are not good enough for responses to act as a surrogate to crash data. The results indicate that motorist feedback can act as a supplement to crash data and give the agency an additional tool for safety evaluation. It should also be noted that as the number of responses required for action increases, the detection rate and false detection rates both decrease. This makes intuitive sense, since as the number of locations indicated by responses is narrowed, then the number of "missed" locations increases, and the number of locations indicated by responses that are not hazardous also decreases. The spikes and valleys in the curves are caused by randomness in both crash counts and risk perception.

Examining Figure 8.2, a strong trend becomes apparent. As the number of responses required for action at a location increases, the likelihood that resources are being expended efficiently increases dramatically. An agency is much less likely to waste resources if there is a delay in action on a location until more than one response is received. Unfortunately, the current legal climate is not conducive to such delays, but if subsequent responses are received on a location after an initial response is investigated, it increases agency confidence in expending resources to further investigate and remediate such a location. Even acting upon a single response results in an approximate success rate of better than 50 percent ( 15 crashes/ 3 years selected as the threshold value), which is an encouraging result.

\subsection{Examining Effects of Gender and Age}

In the literature, several works on risk perception investigated the effects of gender and age on the level of risk perceived. A large amount of research has not been performed in this area with regard to highway safety. This section examines the effects of gender and age on the efficiency rate to see if there is any significant difference in risk perception between genders and age groups. It is hoped that this evaluation will provide insight into risk perception from the highway safety perspective. 


\subsubsection{Detection Evaluation for Gender and Age Groups}

The detection analysis was performed similarly to the analysis conducted in Section 8.2; however, there is a notable difference. The efficiency rate is calculated as the proportion of respondents reporting a truly hazardous location. The sample consisted of 109 respondents after the responses pointing out locations not present in the available database were eliminated. Also, responses reporting sites with non-unique addresses or locations that have undergone recent improvements were removed in the cleaning process described at the beginning of this chapter. The six age categories used in the survey were condensed into three groups: $16-35,36-55$, and 56 or older. The computed efficiency rates for each gender and age group, calculated from the sample of 109 responses, are shown in Table 8.5.

Table 8.5. Number of Responses and Efficiency Rate for Each Evaluation Group

\begin{tabular}{|l|r|r|r|r|r|}
\cline { 2 - 6 } \multicolumn{1}{c|}{} & \multicolumn{2}{c|}{ Gender } & \multicolumn{3}{c|}{ Age Group } \\
\cline { 2 - 6 } \multicolumn{1}{c|}{} & Male & Female & $16-35$ & $36-55$ & \multicolumn{1}{c|}{$56+$} \\
\hline Responses & 59 & 50 & 22 & 59 & 27 \\
\hline Efficiency Rate & 0.5763 & 0.5400 & 0.4545 & 0.5762 & 0.6296 \\
\hline
\end{tabular}

The efficiency rate for each gender and age group was computed in the manner described in Section 8.2, with the threshold crash number set to 15 crashes over three years. The number of crashes each location indicated by respondents was compiled from the ISP crash data. The location was considered hazardous if the crash total for the three years was greater than 15 . The efficiency rate for each respondent group was calculated by dividing the number of responses that pinpointed hazardous locations by the total number of responses for this group. As indicated in Table 8.5, most groups had an efficiency rate of greater than 0.5 . The only exception was the 16-35 age group where the efficiency rate was 0.45 .

\subsubsection{Do Gender and Age Make a Difference?}

Once the efficiency rates have been computed for the investigated groups, the rates can be compared pairwise to see if there is a significant difference between the groups. In order to compare these results, a two-sample test of proportions is used, since the efficiency rates represent approximate proportions of useful responses, which are assumed to be distributed normally. The general equation used in this evaluation is as follows: 


$$
Z=\frac{p_{1}-p_{2}}{\sqrt{\frac{p_{1}\left(1-p_{1}\right)}{n_{1}}+\frac{p_{2}\left(1-p_{2}\right)}{n_{2}}}}
$$

In Equation 3, $\mathrm{Z}$ is the standardized normal variable, $p_{i}$ is the efficiency rate for group $i$, and $n_{i}$ are the number of responses in group $\mathrm{i}$, with $\mathrm{i}=1$ or 2 . In this case, the null hypothesis is that the two groups being compared are not significantly different from each other. The Z-values and resultant significance levels for the two-sided test are shown in Table 8.6.

Table 8.6. Results of Significance Tests Between Groups

\begin{tabular}{|l|r|r|r|r|}
\cline { 2 - 5 } \multicolumn{1}{c|}{} & \multicolumn{4}{c|}{ Comparison } \\
\cline { 2 - 5 } \multicolumn{1}{c|}{} & Gender & $\begin{array}{c}16-35 \text { and } \\
36-55\end{array}$ & $\begin{array}{c}36-55 \text { and } \\
56+\end{array}$ & $\begin{array}{c}16-35 \text { and } \\
56+\end{array}$ \\
\hline Z-value & 0.3800 & -0.9806 & -0.4721 & -1.2409 \\
\hline Significance & 0.7040 & 0.3270 & 0.6384 & 0.2150 \\
\hline
\end{tabular}

The results in Table 8.6 do not provide a sufficient basis to reject the null hypothesis that the efficiency rates are equal. However, it should be noted that as age increases, the efficiency rates also increase, and this is reinforced by the results of Table 8.6, even though the results are not sufficiently significant. This effect is especially noticeable between young drivers (16-25) and the oldest drivers (56 and older). With a larger sample size, it is quite possible that this trend could show significance and consistency with the findings by Renge (1998) that more experienced drivers perceive risks more accurately.

\subsection{Non-Crash Personal Perception of Hazard}

Question three in the questionnaire asks the survey users how they came to the opinion that the location in question is hazardous. Of the possible response options, three of them relate to actual crash experience, and two relate to second-hand knowledge. The second-hand knowledge reduces confidence in the independence of the respondent's information, as well as introducing possible media bias as described by Liu et al. (1998). The crash experience may not provide new information to the analysis if the crash experience is reflected in the crash data for the location. Because of these issues, it is desirable to check what results would be obtained if the analysis presented in the previous section is repeated after the responses indicating crash 
experience or second-hand knowledge are removed. The reduced set of responses will be referred to as the non-crash personal perception (NCPP) of the hazard.

\subsubsection{Binomial Evaluation of NCPP Responses}

A binomial comparison of the NCPP responses was performed in a similar manner as that described in Section 8.1. Using the NCPP response set, there were 21 locations that respondents indicated as hazardous, as opposed to 31 locations indicated with the complete response set. Again, the 260 state-maintained locations were separated into groups based on the number of responses obtained for each location. The five groups and their crash statistics are shown in Table 8.7.

Table 8.7. Groups of Locations Based on Number of Responses per Location (NCPP)

\begin{tabular}{|c|r|r|r|r|}
\hline Group & $\begin{array}{c}\text { Number of } \\
\text { Responses } \\
\text { Per Location }\end{array}$ & $\begin{array}{c}\text { Number of } \\
\text { Locations }\end{array}$ & $\begin{array}{c}\text { Total } \\
\text { Crashes }\end{array}$ & $\begin{array}{c}\text { Avg. Number } \\
\text { of Crashes Per } \\
\text { Location }\end{array}$ \\
\hline A & 4 & 2 & 124 & 62.0 \\
\hline B & 3 & 2 & 58 & 29.0 \\
\hline C & 2 & 3 & 45 & 15.0 \\
\hline D & 1 & 14 & 287 & 20.5 \\
\hline E & 0 & 239 & 1248 & 5.2 \\
\hline
\end{tabular}

As indicated in Table 8.7, the NCPP response set performs fairly well, but the low number of locations is a concern, as shown by the higher average number of crashes in Group D compared to Group C. In order to further examine this, a binomial test was again performed on each of these groups, and the resulting matrix of significance values is shown in Table 8.8.

Table 8.8. Significance Matrix of Locations (NCPP)

\begin{tabular}{|c|c|c|c|c|c|}
\cline { 2 - 6 } \multicolumn{1}{c|}{} & \multicolumn{5}{c|}{ Group } \\
\hline Group & A & B & C & D & E \\
\hline A & & 0.000001 & 0.000000 & 0.000000 & 0.000000 \\
\hline B & & & 0.000598 & 0.011861 & 0.000000 \\
\hline C & & & & 0.981402 & 0.000000 \\
\hline D & & & & & 0.000000 \\
\hline E & & & & & \\
\hline
\end{tabular}


As indicated in the table, the general trend is very similar to the trend that emerged when evaluating the complete set of responses. The only anomaly occurs between locations with one and two responses, for which the difference is the opposite of what is expected. However, the general trend that locations with responses tend to be more hazardous than those locations without responses still holds for the NCPP data.

\subsubsection{Evaluation of Detection Based on NCPP Responses}

The NCPP responses were also evaluated through detection analysis in a way similar to that described in Section 8.2. If the results are better than those obtained when all of the responses were analyzed, then it is recommended that the responses containing crash experience and second-hand knowledge be eliminated in an implementation of the survey tool. Figures 8.3 and 8.4 show the results of the detection analysis presented in a similar manner as in Section 8.2.2.

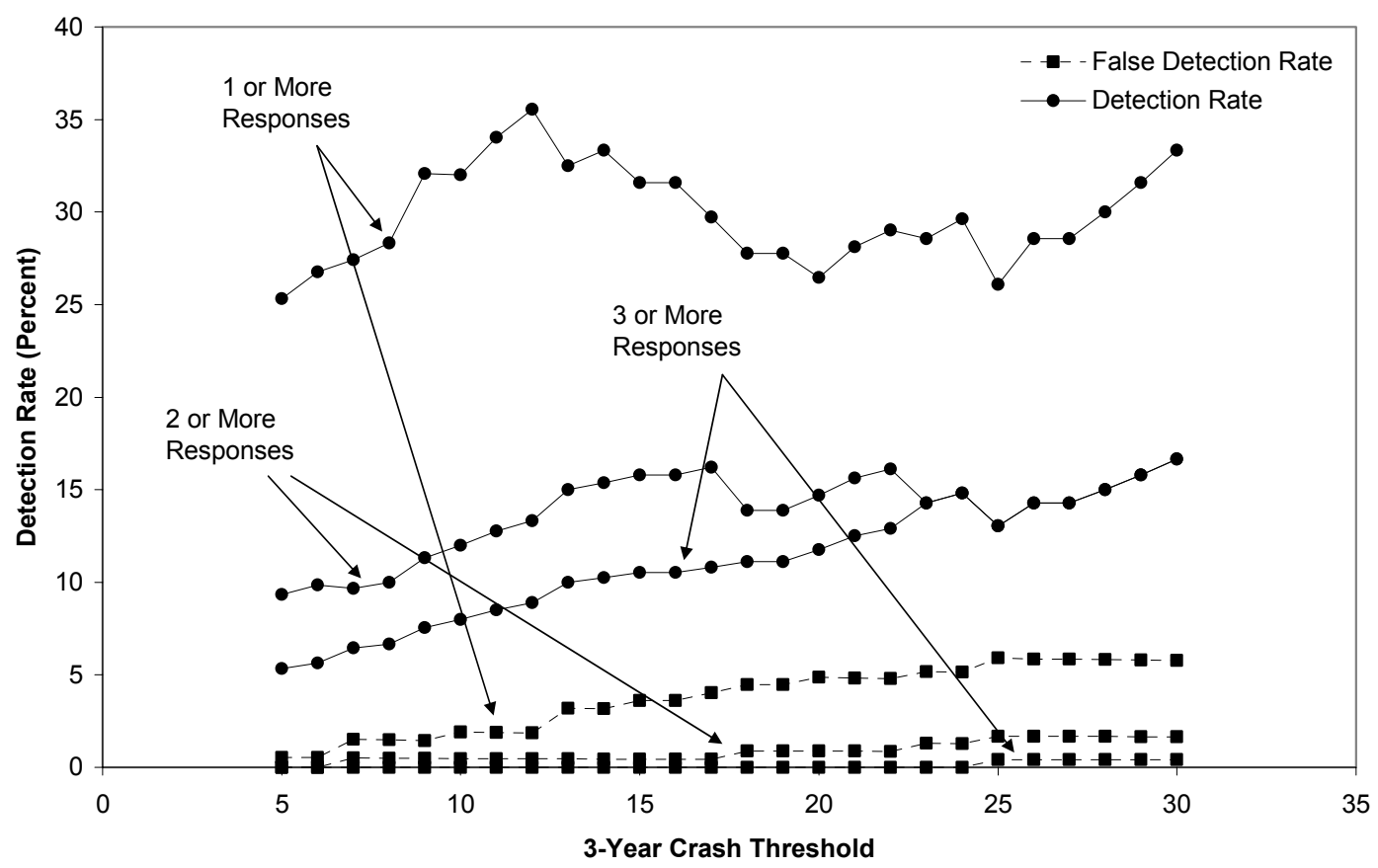

Figure 8.3. Detection Rate Curves for NCPP Responses 


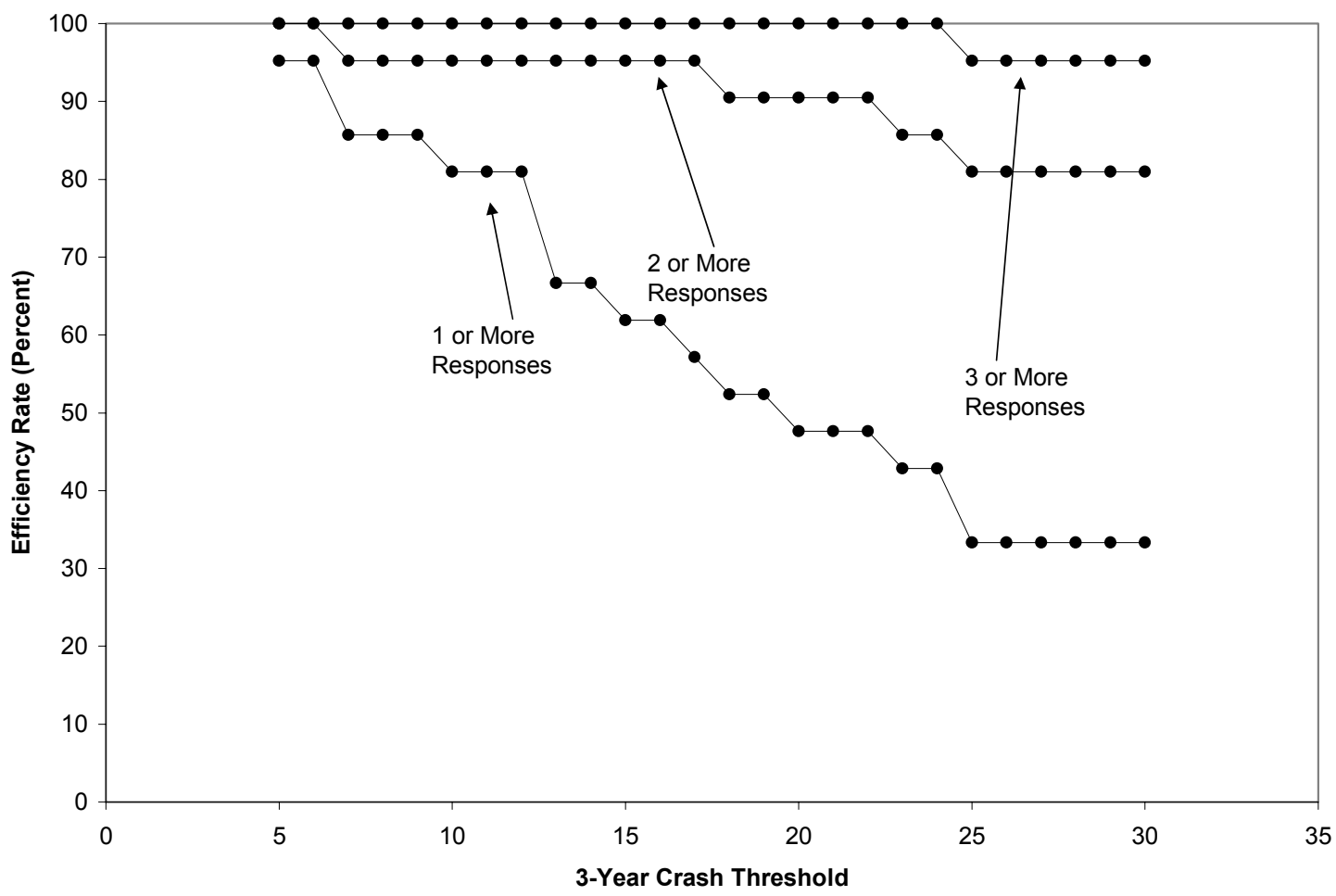

Figure 8.4. Efficiency Rate Curves for NCPP Responses

As indicated in Figures 8.3 and 8.4, the general trends are very similar to those seen in Figures 8.1 and 8.2 when examining the complete data set. The detection rate and false detection rate curves have lower average rates, mainly due to the lower number of overall responses, which naturally shifts the rates downward. Examining the efficiency rate curves, the differences between the curves involving all responses and those excluding crash experience and secondhand knowledge are much less obvious. To better examine the differences in the two trends, the efficiency curves for each case are plotted together in Figure 8.5. 


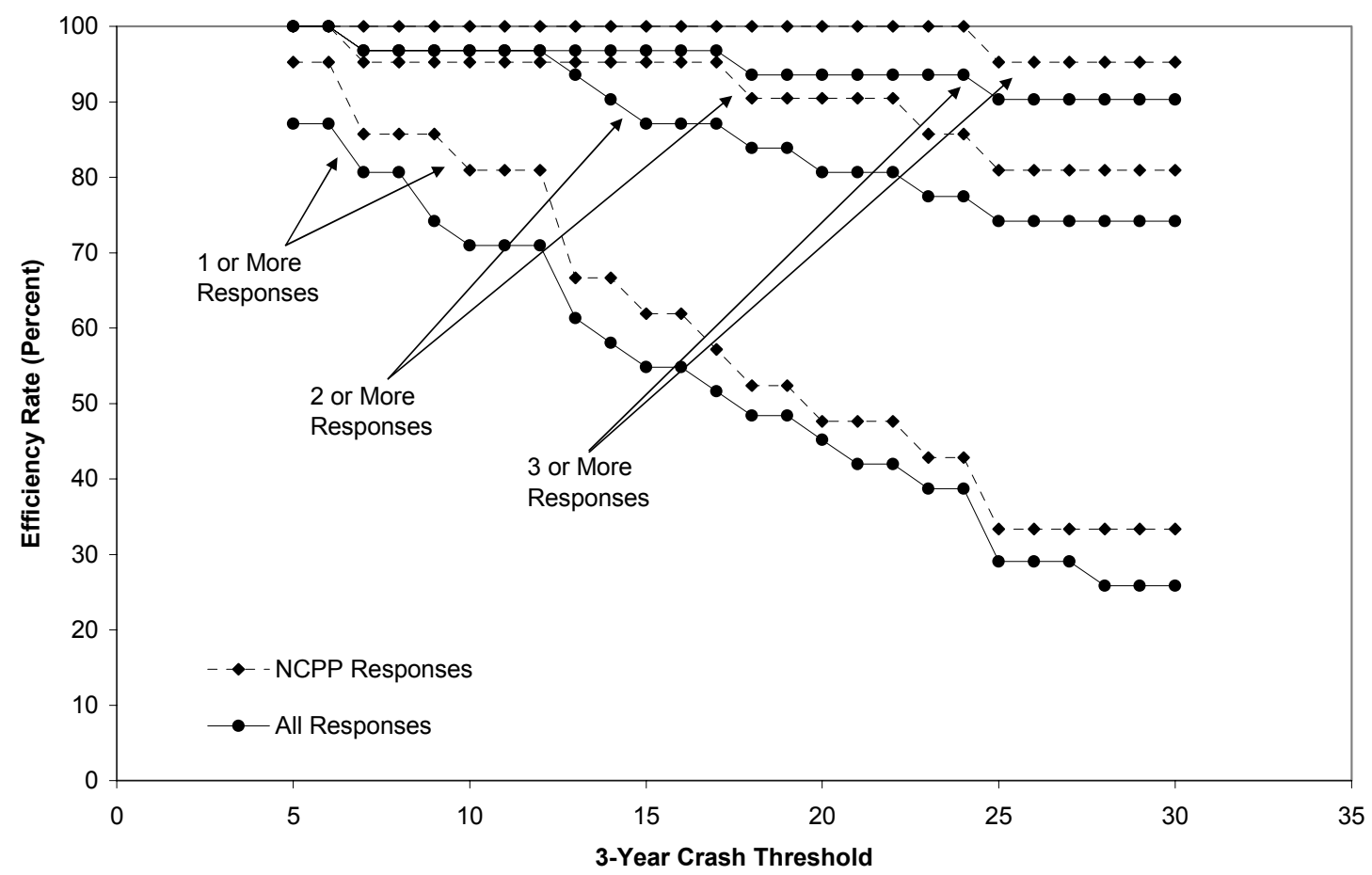

Figure 8.5. Comparison of Efficiency Rate Curves Between Response Sets

As indicated in Figure 8.5, the trends are very similar between the two sets of information in terms of efficiency rates, and the NCPP response curves perform better than those curves in which all information is included. The only concern in this analysis is the small sample sizes involved, especially with regard to the NCPP responses from which only 21 locations were indicated.

Thus, it must be said that, while the initial results are promising as to the benefit of reducing the response data to only those responses that have no crash experience or second-hand knowledge of the hazard, there may be not enough evidence to draw definite conclusions. 


\section{CHAPTER 9. CONCLUSIONS AND RECOMMENDATIONS}

The following chapter presents conclusions from the development and application of the prototype survey, and from the evaluation of the survey tool and the information collected. Recommendations for changes and improvements to the prototype survey for implementation, as well as topics for further research, are discussed.

\subsection{Prototype Survey Tool}

The design of the prototype tool, as described in Chapter 4, was a challenging task, and the final prototype balances the goals of the highway agency for fast, automated access to responses and the user-friendliness and wide-ranging access needed by the public who use the tool. The survey is easily implementable on a single server, since the volume of responses is manageable and the files are not prohibitively large. Required computer equipment is low-cost, as the method requires limited computational resources and standard equipment and software. A secure server with regular maintenance is needed to keep the tool running smoothly.

From the public standpoint, the reception of the survey tool was very good. Most users who completed the survey did so in a thorough and judicious manner. It is also apparent from the user feedback that certain changes, such as more response options for individual questions and more current maps, would be appropriate so as to create a survey that is more tailored to the users. These responses included in the questions that were not used frequently should be eliminated. The minimum information that should be asked the user includes the location of concern, the source of the concern, the user's opinion as to what is causing the problem, and contact information (e-mail, mailing address). Any other survey questions desired by the agency can be added at that agency's discretion.

\subsection{Safety Information Gained}

There was a wealth of safety information obtained from the responses to the prototype survey. Firstly, the respondents were mostly driven from personal experience and not second-hand information, which greatly reduced the chance of bias. A low percentage of the respondents had some form of actual crash experience, so the information was new and not reflected in crash data records. It follows from these results that the bulk of information gained through the survey was 
new information that can be used as a supplement to existing crash data. The user-reported causes of the hazardous situation at the locations were varied and very detailed in some cases, pinpointing some exact situations and objects of concern. This would be very useful to the highway agency when trying to pinpoint exact causes of a safety problem, and would give the agency a good set of starting points for investigation. Although the number of locations within Tippecanoe County were reported by motorists, this number was not overwhelming. The considerable number of locations was due to the aggressive publicity campaign. The number of reports will likely be much lower for an implemented version of the tool and routine operations. The quantity and quality of the safety information provided by the respondents to the survey indicates that such a tool would provide a valuable source of information to agencies investigating hazardous locations.

\subsection{Evaluation of Information for Pedestrian Purpose}

The analyses performed in this research provided a great deal of information with regard to the validity of the information being received through the survey. The results of the binomial testing showed that locations selected by respondents to the survey had a tendency to be significantly more hazardous, based on the assumption that hazardousness increases as crashes increase. One conclusion that may be drawn from the detection analyses is that the responses from the survey alone are not sufficient to detect all hazardous locations. This is apparent from the approximately 40-45 percent detection rate indicated from the detection rate curve for one or more responses. On the other hand, the chance that an agency investigates a location that is reported by motorists and deserves attention is reasonably high and this chance increases dramatically to $85-95 \%$ when reports for the same location are multiple. It can be concluded that the use of motorist feedback as a supplement to crash data is very promising.

Gender was found to have no significant effect on the quality of the information received. Age may be a factor, as the efficiency rates for the survey responses tend to increase as the age of the respondent increases. The sample of responses was not large enough to conclude that the trend is statistically significant.

\section{$\underline{9.4 \text { Summary }}$}

The prototype Internet tool serves as a very effective means of gathering motorist feedback. The tool is friendly and adaptable to both the users and the agency implementing the survey. The 
amount of responses collected is not overwhelming, especially when publicity is not excessive, which provides the agency a chance to respond to each survey. The information gained through the individual responses provides details that are of assistance in not only identifying hazardous locations, but also in pinpointing the causes of the problem at the location. Finally, the survey responses indicate that motorists have a good concept of the hazardousness of locations, even if their opinions are based on non-crash experience and personal observations. 


\section{LIST OF REFERENCES}

1. Chen, Jain-Shiuh and Shih-Cueh Wang. "Comprehensive Evaluation of Traditional Techniques and Proposal of a New Method for Identifying Hazardous Locations." IATSS Research. Vol. 21, No. 2. IATSS, 1997. pp. 143-151.

2. Cohen, Bernard L. "Public perception versus results of scientific risk analysis." Reliability Engineering and System Safety. Vol. 59, No. 1. Elsevier Science Ltd., 1998. pp. 101-105.

3. Cohn, Lawrence D., Susan Macfarlane, Claudia Yanez, and Walter K. Imai. "RiskPerception; Differences Between Adolescents and Adults." Health Psychology. Vol. 14, No. 3. American Psychological Association, 1995. pp. 217-222.

4. DeJoy, David M. "An Examination of Gender Differences in Traffic Accident Risk Perception." Accident Analysis and Prevention. Vol. 24, No. 3. Pergamon Press, 1992. pp. 237-246.

5. Fleming, Mark, and Ronny Lardner. "When is a Risk Not a Risk?" Chemical Engineer. No. 684. Institution of Chemical Engineers, July 8, 1999. pp. 14-17.

6. Greenberg, Michael R. and Dona F. Schneider. "Gender Differences in Risk Perception: Effects Differ in Stressed vs. Non-Stressed Environments." Risk Analysis. Vol. 15, No. 4. Society for Risk Analysis, August 1995. pp. 503-511.

7. Gustafson, Per E. "Gender Differences in Risk Perception: Theoretical and Methodological Perspectives." Risk Analysis. Vol. 18, No. 6. Society for Risk Analysis, 1998. pp. 805-811.

8. Hauer, Ezra, "Identification of 'Sites with Promise.' " Transportation Research Board. $75^{\text {th }}$ Annual Meeting, Washington, D.C., January 1996.

9. Kanellaidis, George, and loannis Dimitropoulos. "Subjective and objective evaluation of risk on roadway curves." Traffic Engineering and Control. Vol. 35, Nos.7-8. July/August 1994. pp. 451-454.

10. Liu, Shiping, Ju-Chin Huang, and Gregory L. Brown. "Information and Risk Perception: A Dynamic Adjustment Process." Risk Analysis. Vol. 18, No. 6. Society for Risk Analysis, December 1998. pp. 689-699.

11. McDaniels, Timothy L., Mark S. Kamlet, and Gregory W. Fischer. "Risk Perception and the Value of Safety." Risk Analysis. Vol. 12, No. 4. Society for Risk Analysis, December 1992. pp. 495-503.

12. Renge, Kazumi. "Drivers' Hazard and Risk Perception, Confidence in Safe Driving, and Choice of Speed." IATSS Research. Vol. 22, No. 2. IATSS, 1998. pp. 103-110.

13. Salter, D., T. Carthy, D. Packham, and N. Rhodes-Defty. "Risk on the Roads: Perceptions of Risk and Competition." Traffic Engineering and Control. May 1993. pp. 236-241.

14. Sandman, Peter M., Paul M. Miller, Branden B. Johnson, and Neil D. Weinstein. "Agency Communication, Community Outrage, and Perception of Risk: Three Simulation Experiments." Risk Analysis. Vol. 15, No. 6. Society for Risk Analysis. 1993. pp. 585-598. 
15. Sjöberg, Lennart. "Factors in Risk Perception." Risk Analysis. Vol. 20, No. 1. Society for Risk Analysis, January 2000. pp. 1-11.

16. Spring, Gary S. and Joseph Hummer. "Identification of Hazardous Highway Locations Using Knowledge-Based GIS: A Case Study." Transportation Research Record 1497.

Transportation Research Board, July 1995. pp. 83-90.

17. Stokes, Robert W. and Madamiyo I. Mutabazi. "Rate-Quality Control Method of Identifying Hazardous Locations." Transportation Research Record 1542. Transportation Research Board, 1996. pp. 44-48.

18. Weiss, Johnathan. "Identification of Hazardous Intersections Based on Potential Crash Reduction". Purdue University Master's Thesis, December 1996. 
APPENDIX A:

TEXT OF SURVEY QUESTIONNAIRE 
1. Where is the danger located?

a. At/Near Intersection

b. Between Intersections

2. If possible, please give the street names at this location.

Road with Unsafe Location: Nearest Crossing Road:

3. How did you learn that this location is unsafe? (Mark all that apply)
a. Witnessed Near-Crash
b. Involved in Near-Crash
c. Witnessed Collision
d. Involved in Collision
e. Involved in Collision with Injury
f. Other Drivers Act Dangerously on a Regular Basis
g. Learned About it from Others
h. Learned About it from TV/Media
i. Other (please specify):

4. What makes this location unsafe? (Mark all that apply)
a. Sight Obstructions
f. Pedestrians
b. Speed
c. Trucks
d. Construction Work
g. Existing Stoplights/Signs
e. High Traffic
h. No Stoplights/Signs
i. Weather
j. Other (please specify):

5. How often do you pass this location?
a. Less than once per week
b. 1-3 times per week
d. Once per day
c. 3-5 times per week
e. Twice per day
f. More than twice per day

6. At what time of day do you usually pass this location? (Mark all that apply)
a. $12 a m-3 a m$
b. $3 a m-6 a m$
f. $\quad 1 p m-4 p m$
c. $6 a m-9 a m$
g. $4 p m-6 p m$
d. $9 a m-11 a m$
h. $6 p m-9 p m$
e. $11 \mathrm{am}-1 \mathrm{pm}$
i. $9 \mathrm{pm}-12 \mathrm{am}$ 
7. If possible, how much extra time would you be willing to spend to bypass this location?
a. Less than 2 minutes
d. 6 to 8 minutes
b. 2 to 4 minutes
e. 8 to 10 minutes
c. 4 to 6 minutes
f. More than 10 minutes

8. Please fill out the following information. (The information is for study purposes only and will be kept confidential)
Age:
a. $16-25$
Gender:
a. Male
b. $26-35$
b. Female
c. $36-45$
d. $46-55$
e. $56-65$
f. $65+$
Home Zip Code:
E-mail address:

9. Feedback to improve the survey.

A. Is the clickable map convenient?
a. Yes
b. Indifferent
c. No

B. Is the site user-friendly?
a. Yes
b. Indifferent
c. No

C. Is the survey readable?
a. Yes
b. Indifferent
c. No

D. Are the question types sufficient?
a. Yes
b. Indifferent
c. No

E. Are the response options adequate?
a. Yes
b. Indifferent
c. No

Please clarify any responses from previous questions that you wish and make any other comments below: 
APPENDIX B:

SURVEY DATA 


\section{COMMENTS ABOUT THE SURVEY DATA}

The following set of survey data consists of the 146 responses to the survey that were considered usable based on the completeness and zip code criteria established in Chapter 5 of this report. The survey data was reformatted from its original form in order to increase readability and to facilitate inclusion into this report. The data presented here focuses solely on the responses of the users to the questions of the survey, and as such, the coordinate data and date/time stamp are not included here. The free-response options for Questions 3 and 4, as well as the closing comments provided by each respondent from the last question of the survey, are included in their original form as written by the respondent and have not been altered. The data tables are broken into two parts, designated $A$ and $B$, which comprise a set of complete response records. For example, Survey Results $1 \mathrm{~A}$ and $1 \mathrm{~B}$ comprise one complete set of responses. When examining the survey data, the sample survey contained in Appendix A may be used as a reference. 
Table B.1. Survey Results $-1 \mathrm{~A}$

\begin{tabular}{|c|c|c|c|c|c|c|c|c|c|c|}
\hline ID & Location & $\mathrm{Q} 3^{1}$ & Q3 (i) ${ }^{2}$ & Q4 & Q4 (j) & Q5 & Q6 & Q7 & Zip & E-mail \\
\hline 1 & $\begin{array}{l}\text { All of New } \\
\text { Castle Rd. }\end{array}$ & $\mathrm{i}$ & $\begin{array}{l}\text { FULL OF } \\
\text { POTHOLES }\end{array}$ & $\mathrm{j}$ & $\begin{array}{c}\text { narrow rd., } \\
\text { large potholes }\end{array}$ & $\begin{array}{c}\text { twice per } \\
\text { day }\end{array}$ & $\mathrm{c}, \mathrm{g}$ & $\begin{array}{l}2-4 \\
\min \end{array}$ & 47905 & \\
\hline 2 & $\begin{array}{l}\text { At } 18 \text { th and } \\
\text { J.R. Hiatt Dr. }\end{array}$ & d & & $a, j$ & \begin{tabular}{|c} 
RED AT $18 \mathrm{TH}$ \\
NORH \\
BOUND \\
GREEN AT \\
HIATT SAME \\
TIME
\end{tabular} & $\begin{array}{c}\text { twice per } \\
\text { day }\end{array}$ & $\mathrm{c}$ & $\begin{array}{l}8-10 \\
\min \end{array}$ & 47905 & $\begin{array}{c}\text { SSLEDD40 } \\
\text { @HOTMAIL.CO } \\
\mathrm{M}\end{array}$ \\
\hline 3 & $\begin{array}{c}\text { At } 18 \text { th St. } \\
\text { and Central } \\
\text { St. }\end{array}$ & $\mathrm{a}, \mathrm{b}, \mathrm{f}, \mathrm{i}$ & $\begin{array}{c}\text { Live on Central } \\
\text { St. }\end{array}$ & $\mathrm{b}, \mathrm{g}, \mathrm{h}, \mathrm{j}$ & $\begin{array}{c}\text { No clear "right } \\
\text { of way" }\end{array}$ & $\begin{array}{c}\text { twice per } \\
\text { day }\end{array}$ & $\mathrm{c}, \mathrm{g}$ & $\begin{array}{c}\text { less } \\
\text { than } 2 \\
\text { min }\end{array}$ & 47905 & $\begin{array}{c}\text { swmckinley@cs.c } \\
\text { om }\end{array}$ \\
\hline 4 & $\begin{array}{l}\text { At } 18 \text { th St. } \\
\text { and Central } \\
\text { St. }\end{array}$ & $\mathrm{f}$ & & $\mathrm{h}$ & & $\begin{array}{c}\text { twice per } \\
\text { day }\end{array}$ & $\mathrm{c}, \mathrm{g}$ & $\begin{array}{c}\text { more } \\
\text { than } 10 \\
\min \end{array}$ & 47905 & $\begin{array}{c}\text { dianems726@cs. } \\
\text { com }\end{array}$ \\
\hline 5 & \begin{tabular}{|} 
At 18th St. \\
and CR $350 \mathrm{~S}$
\end{tabular} & $\mathrm{f}$ & & None & & $\begin{array}{c}\text { more } \\
\text { than } \\
\text { twice per } \\
\text { day }\end{array}$ & $\begin{array}{c}\mathrm{c}, \mathrm{d}, \mathrm{e}, \mathrm{f}, \mathrm{g}, \\
\mathrm{h}\end{array}$ & None & 47909 & \\
\hline 6 & \begin{tabular}{|} 
At 18 th St. \\
and CR $350 \mathrm{~S}$
\end{tabular} & $\mathrm{f}$ & & $\mathrm{g}$ & & $\begin{array}{c}\text { twice per } \\
\text { day }\end{array}$ & $\mathrm{c}, \mathrm{g}$ & $\begin{array}{c}\text { less } \\
\text { than } 2 \\
\text { min }\end{array}$ & 47909 & \\
\hline 7 & $\begin{array}{l}\text { At 18th St. } \\
\text { and Kossuth } \\
\text { St. }\end{array}$ & $\mathrm{a}$ & & $a, j$ & $\begin{array}{c}\text { The way the } \\
\text { road jogs, it is } \\
\text { hard to turn left } \\
\text { on }\end{array}$ & $\begin{array}{l}3-5 \text { times } \\
\text { per week }\end{array}$ & $d, e, f, g, h$ & None & 47975 & $\begin{array}{c}\text { renatebannon@ho } \\
\text { tmail.com }\end{array}$ \\
\hline
\end{tabular}

${ }^{1} \mathrm{Q} 3$ represents Question 3 from the sample survey in App. A. The letter(s) below indicate the respondent's choice(s). ${ }^{2} \mathrm{Q} 3$ (i) represents the free-response from option i to Question 3 in App. A. 
Table B.2. Survey Results - 1B

\begin{tabular}{|c|c|c|c|c|c|c|c|c|c|c|}
\hline ID & Location & $\mathrm{M}$ & $\mathrm{F}$ & Age & Q9 A & Q9 B & Q9 C & Q9 D & Q9 E & Comment \\
\hline 1 & $\begin{array}{l}\text { All of New } \\
\text { Castle Rd. }\end{array}$ & & $\mathrm{Y}$ & $26-35$ & $\mathrm{a}$ & $\mathrm{a}$ & $\mathrm{a}$ & c & $\mathrm{a}$ & $\begin{array}{l}\text { Although this is just a country road, there have been two new homes } \\
\text { built in the past year, with plans for several more soon. The } \\
\text { construction vehicles along with the disgusting oil put down every } \\
\text { summer have created a mine field of potholes. You CAN'T drive on } \\
\text { the road without hitting several of them. People drive way too fast } \\
\text { down the road. IT NEEDS TO BE PAVED!!!!!!!! }\end{array}$ \\
\hline 2 & $\begin{array}{l}\text { At } 18 \text { th and } \\
\text { J.R. Hiatt Dr. }\end{array}$ & Y & & $46-55$ & $\mathrm{a}$ & $\mathrm{a}$ & $\mathrm{a}$ & $\mathrm{a}$ & $\mathrm{a}$ & \\
\hline 3 & $\begin{array}{c}\text { At } 18 \text { th St. } \\
\text { and Central } \\
\text { St. }\end{array}$ & & $\mathrm{Y}$ & $\mid 46-55$ & $\mathrm{a}$ & $\mathrm{a}$ & $\mathrm{a}$ & $\mathrm{a}$ & $\mathrm{a}$ & \\
\hline 4 & $\begin{array}{l}\text { At } 18 \text { th St. } \\
\text { and Central } \\
\text { St. }\end{array}$ & & $\mathrm{Y}$ & $36-45$ & $\mathrm{a}$ & $\mathrm{b}$ & $\mathrm{a}$ & $\mathrm{c}$ & $\mathrm{c}$ & $\begin{array}{l}\text { There are far too many dangerous intersections in this town. The 5-way } \\
\text { at Central, 18th and State Sts. is one of the worst. I'm certain that a } \\
\text { traffic light at this intersection would increase safety. On Main St., in } \\
\text { front of Dollar General, the street coming out from the park is } \\
\text { sometimes impossible to get out onto. I've seen many vehicles just } \\
\text { pulling out dangerously (myself included) just to get onto Main St. } \\
\text { Concord St. and Teal Rd. are also nightmares. The obvious ones are St } \\
\text { Rd. } 26 \text { and St. Rd. } 52 \text {. }\end{array}$ \\
\hline 5 & $\begin{array}{c}\text { At } 18 \text { th St. } \\
\text { and CR } 350 \mathrm{~S}\end{array}$ & & $\mathrm{Y}$ & $36-45$ & b & $\mathrm{b}$ & b & $\mathrm{b}$ & b & \\
\hline 6 & $\begin{array}{c}\text { At 18th St. } \\
\text { and CR } 350 \mathrm{~S}\end{array}$ & $\mathrm{Y}$ & & $26-35$ & $\mathrm{a}$ & $\mathrm{b}$ & $\mathrm{a}$ & c & 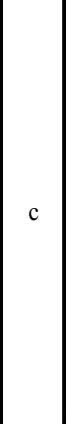 & $\begin{array}{l}\text { I feel there should be more lanes on } 350 \text { South. It's wide enough to } \\
\text { have } 2 \text { lanes running each way (e.g. } 2 \text { lanes going West, and } 2 \text { lanes } \\
\text { going East). This would enable traffic flow much better, especially } \\
\text { with the amount of traffic running from SIA to the West side of town. } \\
\text { Also, the large amount of semi-truck traffic keeps traffic from moving } \\
\text { smoothly. There should also be right turn lanes, in addition to the } \\
\text { already-present left turn and straight lanes at the 4-way stops along } \\
350 \text { South in order to keep traffic moving smoothly. Also, if there is to } \\
\text { be more construction and shop along } 350 \text { South, there should be some } \\
\text { kind of frontage road system. Otherwise, there will be too many } \\
\text { entrances off } 350 \text { South, thereby disrupting traffic flow, and causing } \\
\text { possible collisions between vehicles. }\end{array}$ \\
\hline 7 & $\begin{array}{c}\text { At } 18 \text { th St. } \\
\text { and Kossuth } \\
\text { St. }\end{array}$ & & $\mathrm{Y}$ & $36-45$ & $\mathrm{a}$ & $\mathrm{a}$ & $\mathrm{a}$ & $\mathrm{b}$ & $\mathrm{a}$ & \\
\hline
\end{tabular}


Table B.3. Survey Results $-2 A$

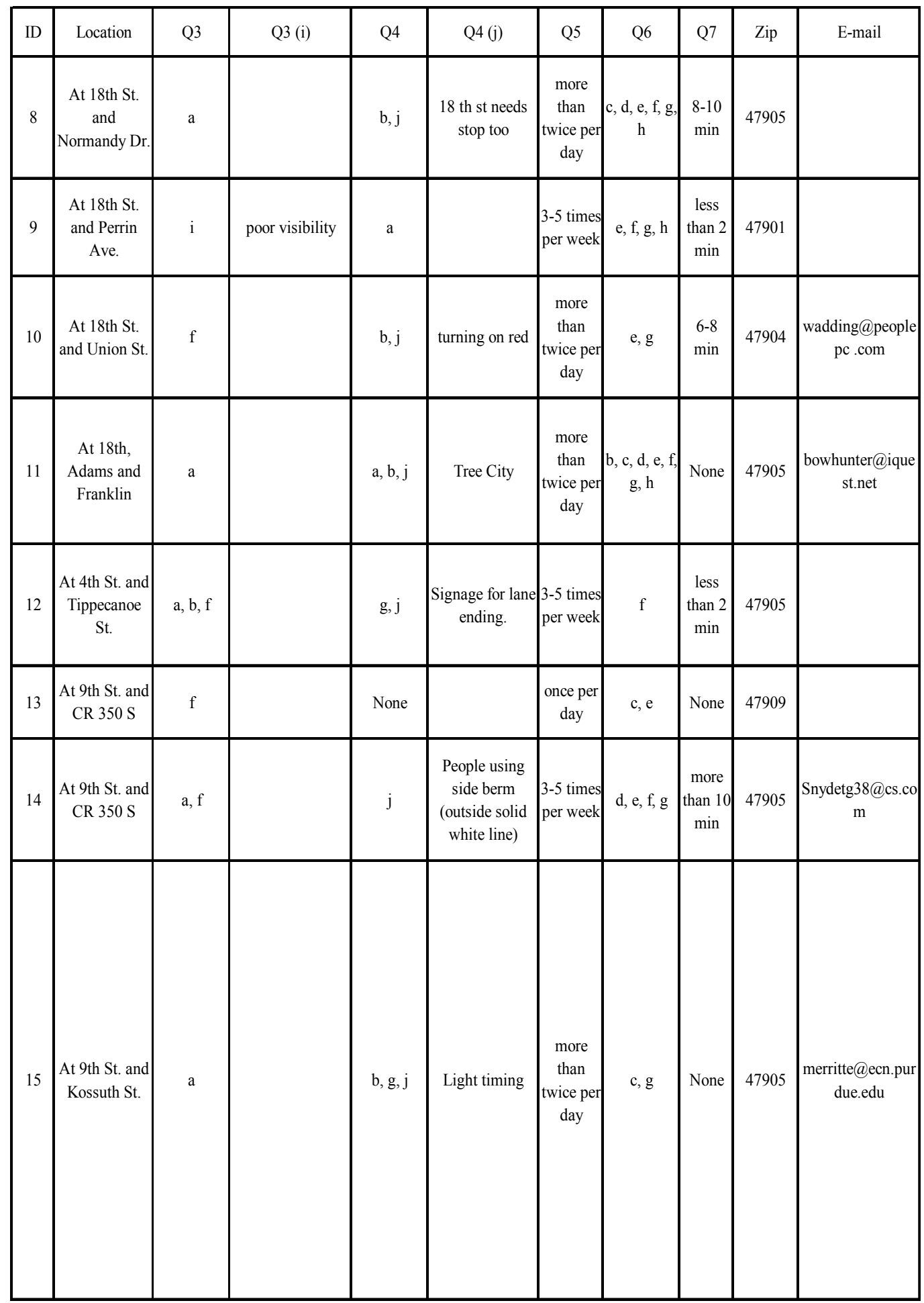


Table B.4. Survey Results - 2B

\begin{tabular}{|c|c|c|c|c|c|c|c|c|c|c|}
\hline ID & Location & M & F & Age & Q9 A & Q9 B & Q9 C & Q9 D & Q9 E & Comment \\
\hline 8 & $\begin{array}{c}\text { At 18th St. } \\
\text { and } \\
\text { Normandy Dr. }\end{array}$ & & Y & $36-45$ & $\mathrm{~b}$ & b & b & $\mathrm{b}$ & b & $\begin{array}{l}\text { Very dangerous pulling out on S.18th street from normandy dr. } \\
\text { because of all new housing. located down S.18th st thank } \mathrm{U}\end{array}$ \\
\hline 9 & $\begin{array}{l}\text { At } 18 \text { th St. } \\
\text { and Perrin } \\
\text { Ave. }\end{array}$ & & $\mathrm{Y}$ & $|46-55|$ & a & b & $\mathrm{a}$ & $\mathrm{b}$ & c & $\begin{array}{l}\text { very difficult to see cars coming on } 18 \text { th Street because of low trees } \\
\text { obstructing visibility from Perrin Avenue }\end{array}$ \\
\hline 10 & $\begin{array}{l}\text { At } 18 \text { th St. } \\
\text { and Union St. }\end{array}$ & Y & & $56-65$ & $\mathrm{a}$ & $\mathrm{a}$ & $\mathrm{a}$ & $\mathrm{a}$ & $\mathrm{a}$ & $\begin{array}{l}\text { people turning right on red and people running the light comeing down } \\
\text { the hill. I will set } 30 \mathrm{sec} \text {. to make sure they stop }\end{array}$ \\
\hline 11 & $\begin{array}{l}\text { At 18th, } \\
\text { Adams and } \\
\text { Franklin }\end{array}$ & Y & & $|46-55|$ & $\mathrm{a}$ & $\mathrm{a}$ & $\mathrm{a}$ & b & b & $\begin{array}{l}\text { This is really a general statement about the trees lining our streets and } \\
\text { obstructing the view and to get onto with the direction of flow let alone } \\
\text { across or the opposite direction. The trees are nice but?????? What } \\
\text { other kind of tree can be planted that is not a low tree like the } \\
\text { flowering crabs. }\end{array}$ \\
\hline 12 & $\begin{array}{c}\text { At 4th St. and } \\
\text { Tippecanoe } \\
\text { St. }\end{array}$ & & Y & $56-65$ & b & $\mathrm{a}$ & $\mathrm{a}$ & b & $\mathrm{b}$ & $\begin{array}{l}\text { When traveling Northbound on } 4 \text { th Street, the road narrows from two } \\
\text { lanes into a single lane after the intersection. There is a sign there but } \\
\text { should be one that states that the right lane ends after the intersection, } \\
\text { thus avoiding confusion. }\end{array}$ \\
\hline 13 & $\begin{array}{c}\text { At 9th St. and } \\
\text { CR } 350 \mathrm{~S}\end{array}$ & & Y & $36-45$ & b & $\mathrm{b}$ & $\mathrm{b}$ & b & $\mathrm{b}$ & \\
\hline 14 & $\begin{array}{l}\text { At 9th St. and } \\
\text { CR } 350 \mathrm{~S}\end{array}$ & & Y & $|56-65|$ & $\mathrm{a}$ & $\mathrm{a}$ & $\mathrm{a}$ & $\mathrm{a}$ & c & $\begin{array}{l}\text { If one wants to stay in the traffic lane and wait for the intersection to } \\
\text { turn right, when you go to turn, you are cut off by others "passing" on } \\
\text { the right, off the regular lane. There are several intersections along } 350 \\
\text { which have the same situation, I just chose one. Thanks }\end{array}$ \\
\hline 15 & $\begin{array}{c}\text { At 9th St. and } \\
\text { Kossuth St. }\end{array}$ & Y & & $46-55$ & c & b & $\mathrm{a}$ & b & b & $\begin{array}{l}\text { The light at the inersection is adjusted so that all Kossuth traffic } \\
\text { MUST stop. If the person at the light is going through and the second } \\
\text { person is } 1 / 2 \text { block in back of them. The light turns red for the second } \\
\text { car. About a } 5 \text { sec light. Most lights are } 30 \text { to } 45 \text { sec lights allowing the } \\
\text { second car a smooth natural time to 'make' the light! This light inhibits } \\
\text { the second car if it is not setting directly on the sensors. SO some of the } \\
\text { local youth are learning to ACCELERATE ( } 55 \text { mph? not sure?) and } \\
\text { cross Kossuth on the 'Red' (very Red because the light is 'quick'). And } \\
\text { someone is going to get hit. All Kossuth (east west) traffic MUST stop } \\
\text { sit on the sensor and wait! I myself find this 'light's timing' VERY } \\
\text { frustrating. It seems to be a 'Stop' light not a signal light. As all } \\
\text { Kossuth traffic are always required to stop and seemingly can never } \\
\text { 'catch' the light on green. 9th street is allowed more time. It has sensors } \\
\text { about } 1 / 2 \text { block back allowing the next car through or at least not } \\
\text { cutting them short. Thanks for this allowing this input, Ed }\end{array}$ \\
\hline
\end{tabular}


Table B.5. Survey Results - 3A

\begin{tabular}{|c|c|c|c|c|c|c|c|c|c|c|}
\hline ID & Location & Q3 & Q3 (i) & Q4 & Q4 (j) & Q5 & Q6 & Q7 & Zip & E-mail \\
\hline 16 & $\begin{array}{c}\text { At Cherry Ln. } \\
\text { and Purdue } \\
\text { Golf Course } \\
\text { Entrance }\end{array}$ & $\mathrm{f}, \mathrm{i}$ & $\begin{array}{c}\text { jogger need a } \\
\text { jogging path }\end{array}$ & $\mathrm{b}, \mathrm{j}$ & $\begin{array}{l}\text { too many } \\
\text { joggers }\end{array}$ & $\begin{array}{l}3-5 \text { times } \\
\text { per week }\end{array}$ & c, d, e, f, g & None & 47905 & 1 \\
\hline 17 & $\begin{array}{c}\text { At Concord } \\
\text { Rd. and Brady } \\
\text { Ln. }\end{array}$ & $\mathrm{a}, \mathrm{b}, \mathrm{c}$ & & $\mathrm{a}, \mathrm{c}, \mathrm{g}$ & & $\begin{array}{c}\text { more } \\
\text { than } \\
\text { twice per } \\
\text { day }\end{array}$ & $\mathrm{f}, \mathrm{h}, \mathrm{i}$ & $\begin{array}{l}8-10 \\
\min \end{array}$ & 47909 & $\begin{array}{c}\text { tegdirb27@hotma } \\
\text { il.com }\end{array}$ \\
\hline 18 & $\begin{array}{c}\text { At Concord } \\
\text { Rd. and Brady } \\
\text { Ln. }\end{array}$ & $\mathrm{a}, \mathrm{f}$ & & $\mathrm{h}$ & & $\begin{array}{c}\text { twice per } \\
\text { day }\end{array}$ & $\mathrm{d}, \mathrm{f}, \mathrm{g}$ & $\begin{array}{c}2-4 \\
\min \end{array}$ & 47909 & \\
\hline 19 & $\begin{array}{c}\text { At Concord } \\
\text { Rd. and Brady } \\
\text { Ln. }\end{array}$ & $\mathrm{i}$ & $\begin{array}{c}\text { go to \& from work } \\
\text { through this } \\
\text { intersection }\end{array}$ & $\mathrm{h}$ & & $\begin{array}{l}3-5 \text { times } \\
\text { per week }\end{array}$ & $\mathrm{c}, \mathrm{h}$ & None & 47905 & \\
\hline 20 & \begin{tabular}{|c} 
At Concord \\
Rd. and Brady \\
Ln.
\end{tabular} & $\mathrm{f}$ & & $\mathrm{g}$ & & $\begin{array}{c}\text { once per } \\
\text { day }\end{array}$ & $\mathrm{d}, \mathrm{f}, \mathrm{h}$ & None & 47909 & $\begin{array}{c}\text { sheila.zadoks@ve } \\
\text { rizon.net }\end{array}$ \\
\hline 21 & \begin{tabular}{|c|} 
At Concord \\
Rd. and Brady \\
Ln.
\end{tabular} & $\mathrm{a}, \mathrm{f}$ & & $\mathrm{h}$ & & $\begin{array}{c}\text { twice per } \\
\text { day }\end{array}$ & c, g & $\begin{array}{l}4-6 \\
\min \end{array}$ & 47909 & \\
\hline 22 & $\begin{array}{l}\text { At Concord } \\
\text { Rd. and CR } \\
\quad 350 \mathrm{~S}\end{array}$ & $\mathrm{f}$ & & None & & $\begin{array}{c}\text { twice per } \\
\text { day }\end{array}$ & $\mathrm{d}, \mathrm{f}, \mathrm{h}$ & None & 47909 & \\
\hline 23 & $\begin{array}{c}\text { At CR } 500 \mathrm{E} \\
\text { and McCarty } \\
\text { Ln. }\end{array}$ & $\mathrm{f}$ & & $\mathrm{a}, \mathrm{b}, \mathrm{h}$ & & $\begin{array}{c}\text { twice per } \\
\text { day }\end{array}$ & $\mathrm{c}, \mathrm{f}, \mathrm{g}$ & $\begin{array}{l}\text { less } \\
\text { than } 2 \\
\text { min }\end{array}$ & 47905 & \\
\hline 24 & $\begin{array}{c}\text { At CR } 500 \mathrm{E} \\
\text { and Meijer } \\
\text { Entrance }\end{array}$ & $\mathrm{f}$ & & $\mathrm{j}$ & $\begin{array}{l}\text { No over head } \\
\text { lane signs }\end{array}$ & None & $\mathrm{c}, \mathrm{e}, \mathrm{g}$ & $\begin{array}{c}\text { more } \\
\text { than } 10 \\
\text { min }\end{array}$ & 47905 & \\
\hline 25 & $\begin{array}{c}\text { At Creasy Ln. } \\
\text { and } \\
\text { Greenbush St. }\end{array}$ & $\mathrm{a}, \mathrm{c}, \mathrm{f}$ & & $\mathrm{c}, \mathrm{g}$ & & $\begin{array}{c}\text { twice per } \\
\text { day }\end{array}$ & f, g & $\begin{array}{c}\text { less } \\
\text { than } 2 \\
\text { min }\end{array}$ & 47905 & $\begin{array}{c}\text { wayne.carter@gte } \\
\text {.net }\end{array}$ \\
\hline 26 & $\begin{array}{c}\text { At Creasy Ln. } \\
\text { and } \\
\text { Kensington } \\
\text { Dr. }\end{array}$ & $b, i$ & $\begin{array}{c}\text { saw collisions } \\
\text { after fact }\end{array}$ & $\mathrm{a}, \mathrm{b}, \mathrm{i}$ & & $\begin{array}{l}3-5 \text { times } \\
\text { per week }\end{array}$ & $\mathrm{d}, \mathrm{g}$ & $\begin{array}{l}8-10 \\
\min \end{array}$ & 47905 & \\
\hline
\end{tabular}


Table B.6. Survey Results - 3B

\begin{tabular}{|c|c|c|c|c|c|c|c|c|c|c|}
\hline ID & Location & M & $\mathrm{F}$ & Age & Q9 A & Q9 B & Q9 C & Q9 D & Q9 E & Comment \\
\hline 16 & $\begin{array}{l}\text { At Cherry Ln. } \\
\text { and Purdue } \\
\text { Golf Course } \\
\text { Entrance }\end{array}$ & $\mathrm{Y}$ & & $56-65$ & $\mathrm{a}$ & $\mathrm{a}$ & a & c & b & $\begin{array}{l}\text { The golf cart are along the road for Ackerman and cross Cherry Rd. } \\
\text { The joggers in the hundreds jog along the road. We need a sidewalk } \\
\text { for jogging that is planted for beauty. }\end{array}$ \\
\hline 17 & $\begin{array}{c}\text { At Concord } \\
\text { Rd. and Brady } \\
\text { Ln. }\end{array}$ & & $\mathrm{Y}$ & $36-45$ & $\mathrm{a}$ & $\mathrm{a}$ & $\mathrm{a}$ & b & $\mathrm{a}$ & $\begin{array}{l}\text { Obstruction for drivers traveling east on Brady. They frequently do not } \\
\text { see the car at stop sign heading north on Concord. }\end{array}$ \\
\hline 18 & $\begin{array}{c}\text { At Concord } \\
\text { Rd. and Brady } \\
\text { Ln. }\end{array}$ & & $\mathrm{Y}$ & $56-65$ & $\mathrm{a}$ & $\mathrm{a}$ & a & a & $\mathrm{a}$ & $\begin{array}{l}\text { Most days from 3:00PM until after six traffic will be backed up past } \\
\text { the telephone co. entrance on Brady. People will take a short cut } \\
\text { through Henry Poor Lumber co. parking lot to avoid the intersection. } \\
\text { This intersection desperately needs a traffic signal. }\end{array}$ \\
\hline 19 & $\begin{array}{c}\text { At Concord } \\
\text { Rd. and Brady } \\
\text { Ln. }\end{array}$ & $\mathrm{Y}$ & & $26-35$ & $\mathrm{a}$ & $\mathrm{a}$ & $\mathrm{a}$ & $\mathrm{a}$ & a & \\
\hline 20 & $\begin{array}{c}\text { At Concord } \\
\text { Rd. and Brady } \\
\text { Ln. }\end{array}$ & & $\mathrm{Y}$ & $36-45$ & $\mathrm{a}$ & $\mathrm{a}$ & $\mathrm{a}$ & $\mathrm{a}$ & b & $\begin{array}{l}\text { This intersection handles an amazing amount of traffice for a two lane } \\
\text { road. That intersection needs to be widened and a light installed. }\end{array}$ \\
\hline 21 & $\begin{array}{c}\text { At Concord } \\
\text { Rd. and Brady } \\
\text { Ln. }\end{array}$ & & $\mathrm{Y}$ & $26-35$ & $\mathrm{a}$ & $\mathrm{a}$ & a & $\mathrm{a}$ & $\mathrm{a}$ & \\
\hline 22 & $\begin{array}{l}\text { At Concord } \\
\text { Rd. and CR } \\
\quad 350 \mathrm{~S}\end{array}$ & & $\mathrm{Y}$ & $36-45$ & b & b & b & b & b & \\
\hline 23 & $\begin{array}{l}\text { At CR } 500 \text { E } \\
\text { and McCarty } \\
\text { Ln. }\end{array}$ & & $\mathrm{Y}$ & $26-35$ & b & $\mathrm{a}$ & a & $\mathrm{a}$ & $\mathrm{a}$ & \\
\hline 24 & $\begin{array}{l}\text { At CR } 500 \mathrm{E} \\
\text { and Meijer } \\
\text { Entrance }\end{array}$ & $\mathrm{Y}$ & & $65+$ & a & $\mathrm{a}$ & $\mathrm{a}$ & b & $\mathrm{b}$ & $\begin{array}{l}\text { Coming from the west approaching the entrance to the Meijer store, if } \\
\text { you are in the right lane you must turn right in to Meijer. Because there } \\
\text { are not over head signs marking lanes, people not use to the road get in } \\
\text { the wrong lane to go straight. }\end{array}$ \\
\hline 25 & $\begin{array}{l}\text { At Creasy Ln. } \\
\text { and } \\
\text { Greenbush St. }\end{array}$ & & Y & $36-45$ & $\mathrm{c}$ & $\mathrm{c}$ & $\mathrm{a}$ & $\mathrm{b}$ & $\mathrm{b}$ & $\begin{array}{l}\text { The intersection at Greenbush and Creasy is so that there could be } 8 \\
\text { vehicles there at one time with a } 4 \text {-way stop sign. It is a very busy } \\
\text { intersection at times, especially at times when people are getting off } \\
\text { work. There needs to be a stoplight at that intersection. I'm surprised } \\
\text { people don't get killed there everyday. }\end{array}$ \\
\hline 26 & $\begin{array}{l}\text { At Creasy Ln. } \\
\text { and } \\
\text { Kensington } \\
\text { Dr. }\end{array}$ & Y & & $56-65$ & $\mathrm{a}$ & $\mathrm{a}$ & $\mathrm{a}$ & $\mathrm{a}$ & $\mathrm{a}$ & $\begin{array}{l}\text { Creasy lane was widened to } 4 \text { lanes and then a privacy fence } 6 \text { high } \\
\text { was an option offered to home owners. Most owners took the fence and } \\
\text { now that causes an obstruction looking north while going east. }\end{array}$ \\
\hline
\end{tabular}


Table B.7. Survey Results $-4 \mathrm{~A}$

\begin{tabular}{|c|c|c|c|c|c|c|c|c|c|c|}
\hline ID & Location & Q3 & Q3 (i) & Q4 & Q4 (j) & Q5 & Q6 & Q7 & Zip & E-mail \\
\hline 27 & $\begin{array}{l}\text { At Creasy Ln. } \\
\text { and Ross Rd. }\end{array}$ & $\mathrm{a}, \mathrm{b}, \mathrm{c}, \mathrm{f}, \mathrm{g}$ & & $\mathrm{b}, \mathrm{c}, \mathrm{h}, \mathrm{j}$ & $\begin{array}{c}\text { Increase in Ivy } \\
\text { Tech traffic }\end{array}$ & \begin{tabular}{|c} 
\\
more \\
than \\
twice per \\
day
\end{tabular} & $\mathrm{c}, \mathrm{e}, \mathrm{f}, \mathrm{g}$ & $\begin{array}{l}8-10 \\
\min \end{array}$ & 47909 & \\
\hline 28 & $\begin{array}{c}\text { At } \\
\text { Cumberland } \\
\text { Ave. and } \\
\text { Salisbury St. }\end{array}$ & $\mathrm{a}$ & & $\mathrm{a}$ & & $\begin{array}{c}\text { twice per } \\
\text { day }\end{array}$ & $\mathrm{c}, \mathrm{g}$ & $\begin{array}{l}2-4 \\
\min \end{array}$ & 47906 & \\
\hline 29 & $\begin{array}{c}\text { At Dehart St. } \\
\text { and Robinson } \\
\text { St. }\end{array}$ & $\mathrm{a}, \mathrm{b}, \mathrm{f}$ & & $\mathrm{a}, \mathrm{b}, \mathrm{i}$ & & $\begin{array}{c}\text { once per } \\
\text { day }\end{array}$ & None & $\begin{array}{l}4-6 \\
\min \end{array}$ & 47906 & \\
\hline 30 & $\begin{array}{c}\text { At Dehart St. } \\
\text { and Robinson } \\
\text { St. }\end{array}$ & $\mathrm{i}$ & poor visibility & $\mathrm{a}$ & & $\begin{array}{c}\text { twice per } \\
\text { day }\end{array}$ & $\mathrm{c}, \mathrm{g}$ & $\begin{array}{l}2-4 \\
\min \end{array}$ & 47906 & \\
\hline 31 & $\begin{array}{c}\text { At Dodge St. } \\
\text { and } \\
\text { Northwestern } \\
\text { Ave. }\end{array}$ & $\mathrm{a}, \mathrm{f}, \mathrm{g}$ & & $\mathrm{a}, \mathrm{f}$ & & $\begin{array}{l}1-3 \text { times } \\
\text { per week }\end{array}$ & $\mathrm{g}$ & $\begin{array}{c}\text { less } \\
\text { than } 2 \\
\text { min }\end{array}$ & 47906 & \\
\hline 32 & $\begin{array}{l}\text { At Elston Rd. } \\
\text { and Beck Ln. }\end{array}$ & $\mathrm{f}$ & & $\mathrm{g}$ & & $\begin{array}{c}\text { than } \\
\text { twice per } \\
\text { day }\end{array}$ & $\mathrm{c}, \mathrm{h}$ & $\begin{array}{l}2-4 \\
\min \end{array}$ & 47909 & $\begin{array}{l}\text { rob@rob- } \\
\text { graves.com }\end{array}$ \\
\hline 33 & $\begin{array}{l}\text { At I- } 65 \text { and } \\
\text { SR } 25\end{array}$ & $\mathrm{a}, \mathrm{b}, \mathrm{f}, \mathrm{g}, \mathrm{i}$ & $\begin{array}{c}\text { personal } \\
\text { experience }\end{array}$ & $\mathrm{a}, \mathrm{b}, \mathrm{h}$ & & $\begin{array}{l}3-5 \text { times } \\
\text { per week }\end{array}$ & $\mathrm{c}, \mathrm{g}$ & $\begin{array}{c}\text { less } \\
\text { than } 2 \\
\text { min }\end{array}$ & 47906 & $\begin{array}{c}\text { FMSTRUCK@ao } \\
\text { 1.com }\end{array}$ \\
\hline 34 & $\begin{array}{l}\text { At I-65 and } \\
\text { SR } 26\end{array}$ & $\mathrm{f}, \mathrm{h}$ & & $g, j$ & $\begin{array}{l}\text { turn signal is } \\
\text { only green for a } \\
\text { few seconds }\end{array}$ & $\begin{array}{c}\text { less than } \\
\text { once per } \\
\text { week }\end{array}$ & None & $\begin{array}{l}2-4 \\
\min \end{array}$ & 47906 & \\
\hline
\end{tabular}


Table B.8. Survey Results - 4B

\begin{tabular}{|c|c|c|c|c|c|c|c|c|c|c|}
\hline ID & Location & M & $\mathrm{F}$ & Age & Q9 A & Q9 B & Q9 C & Q9 D & Q9 E & Comment \\
\hline 27 & $\begin{array}{l}\text { At Creasy Ln. } \\
\text { and Ross Rd. }\end{array}$ & & $\mathrm{Y}$ & $26-35 \mid$ & $\mathrm{a}$ & $\mathrm{a}$ & $\mathrm{a}$ & $\mathrm{a}$ & $\mathrm{a}$ & $\begin{array}{l}\text { I realize that this is a 'new' Ivy Tech building, but Lafayette has known } \\
\text { about the increase in traffic that would occur for over a year now. And } \\
\text { with Menard's going in across the street and the new library branch to } \\
\text { open soon, the intersection will only become more dangerous. Trying } \\
\text { to cross traffic at that spot has always been a 'gun it and go' situation } \\
\text { and there is no alternative way to bypass that area. I hope that there is } \\
\text { some sort of plan to be installed before the snow flies! Thank you for } \\
\text { offering this website - there are more dangerous intersections in } \\
\text { Lafayette, but this one is going to fast become the most dangerous in } \\
\text { the area if something is not done to help the situation. }\end{array}$ \\
\hline 28 & $\begin{array}{l}\text { At } \\
\text { Cumberland } \\
\text { Ave. and } \\
\text { Salisbury St. }\end{array}$ & $\mathrm{Y}$ & & $56-65$ & $\mathrm{a}$ & $\mathrm{a}$ & $\mathrm{a}$ & $\mathrm{a}$ & $\mathrm{c}$ & $\begin{array}{l}\text { this is a very dangerous intersection. there is limited visibility when } \\
\text { westbound turning south onto salisbury. there are } 2 \text { posts, weeds or } \\
\text { flowers, and trees obstructing the view of oncoming eastbound } \\
\text { cumberland traffic. }\end{array}$ \\
\hline 29 & $\begin{array}{c}\text { At Dehart St. } \\
\text { and Robinson } \\
\text { St. }\end{array}$ & $\mathrm{Y}$ & & $16-25 \mid$ & $\mathrm{a}$ & $\mathrm{a}$ & $\mathrm{a}$ & $\mathrm{a}$ & $\mathrm{a}$ & \\
\hline 30 & $\begin{array}{c}\text { At Dehart St. } \\
\text { and Robinson } \\
\text { St. }\end{array}$ & $\mathrm{Y}$ & & $56-65$ & b & b & b & b & b & $\begin{array}{l}\text { There is an elm tree with a thick trunk and branches that hang down so } \\
\text { that when one is heading west on DeHart, you have a hard time seeing } \\
\text { what is coming north on Robinson. Either trimming the tree, or totally } \\
\text { removing it (preferably), would help. }\end{array}$ \\
\hline 31 & $\begin{array}{l}\text { At Dodge St. } \\
\text { and } \\
\text { Northwestern } \\
\text { Ave. }\end{array}$ & $\mathrm{Y}$ & & $16-25 \mid$ & $\mathrm{a}$ & a & $\mathrm{a}$ & $\mathrm{c}$ & c & $\begin{array}{l}\text { Turning from Dogde onto Northwestern is unsafe. There is not } \\
\text { adequate view to see if cars are coming northbond on Northwestern }\end{array}$ \\
\hline 32 & $\begin{array}{l}\text { At Elston Rd. } \\
\text { and Beck Ln. }\end{array}$ & $\mathrm{Y}$ & & $16-25$ & $\mathrm{a}$ & a & a & $\mathrm{a}$ & $\mathrm{a}$ & $\begin{array}{l}\text { I believe that having a four way stop may be worse than having a two- } \\
\text { way stop. I think they traffic on S. Beck should move freely and the } \\
\text { traffic on Elston Rd should stop. People are sometimes flying thru the } \\
\text { intersection because it is a four way stop and they think they are safe } \\
\text { and "that other people will stop for me" kind of attitudes. I believe just } \\
\text { stopping the traffic on Elston would have a positive effect. Just my } \\
\text { thoughts. }\end{array}$ \\
\hline 33 & $\begin{array}{l}\text { At I-65 and } \\
\quad \text { SR } 25\end{array}$ & $\mathrm{Y}$ & & $26-35$ & $\mathrm{c}$ & $\mathrm{a}$ & $\mathrm{a}$ & $\mathrm{a}$ & $\mathrm{a}$ & $\begin{array}{l}\text { Coming from south bound lanes of I- } 65 \text { during all daylight hours, and } \\
\text { in late evening, it is nearly impossible to SAFELY make a left turn to } \\
\text { go north on State Road } 25 \text {. Likewise it is very difficult to make a left } \\
\text { from south bound S.R. } 25 \text { onto S.B. I- } 65 \text {. This intersection has needed } \\
\text { a traffic signal for almost } 10 \text { years. }\end{array}$ \\
\hline 34 & $\begin{array}{l}\text { At I-65 and } \\
\text { SR } 26\end{array}$ & $\mathrm{Y}$ & & $36-45$ & a & $\mathrm{a}$ & a & $\mathrm{a}$ & $\mathrm{c}$ & \\
\hline
\end{tabular}


Table B.9. Survey Results $-5 \mathrm{~A}$

\begin{tabular}{|c|c|c|c|c|c|c|c|c|c|c|}
\hline ID & Location & Q3 & Q3 (i) & Q4 & Q4 (j) & Q5 & Q6 & Q7 & Zip & E-mail \\
\hline 35 & $\begin{array}{l}\text { At I-65 and } \\
\text { SR } 43\end{array}$ & $\mathrm{i}$ & 43 south & $\mathrm{j}$ & $\begin{array}{l}\text { should be a } \\
\text { gateway }\end{array}$ & $\begin{array}{c}3-5 \\
\text { times } \\
\text { per } \\
\text { week }\end{array}$ & None & $\begin{array}{c}\text { less } \\
\text { than } \\
2 \text { min }\end{array}$ & 47905 & $\begin{array}{c}\text { larry47905@h } \\
\text { ome.com }\end{array}$ \\
\hline 36 & $\begin{array}{l}\text { At I-65 and } \\
\text { SR } 43\end{array}$ & $\mathrm{a}, \mathrm{b}, \mathrm{f}$ & & $\mathrm{a}$ & & $\begin{array}{c}3-5 \\
\text { times } \\
\text { per } \\
\text { week }\end{array}$ & $\begin{array}{c}\mathrm{c}, \mathrm{d}, \mathrm{e}, \mathrm{f}, \\
\mathrm{g}, \mathrm{h}\end{array}$ & $\begin{array}{l}4-6 \\
\min \end{array}$ & 47906 & $\begin{array}{c}\text { gm543@hom } \\
\text {.com }\end{array}$ \\
\hline 37 & $\begin{array}{c}\text { At Kossuth } \\
\text { St. and 26th } \\
\text { St. }\end{array}$ & $\mathrm{a}, \mathrm{c}, \mathrm{f}$ & & $\mathrm{a}, \mathrm{b}, \mathrm{c}, \mathrm{j}$ & $\begin{array}{c}\text { LUM has a } \\
\text { site within } \\
\text { the church } \\
\text { on the corner } \\
\text { of }\end{array}$ & $\begin{array}{c}\text { more } \\
\text { than } \\
\text { twice } \\
\text { per day }\end{array}$ & $\begin{array}{l}b, c, d, e, \\
f, g, h, i\end{array}$ & $\begin{array}{c}\text { less } \\
\text { than } \\
2 \mathrm{~min}\end{array}$ & 47904 & \\
\hline 38 & $\begin{array}{l}\text { At Main St. } \\
\text { and 3rd St. }\end{array}$ & $\mathrm{a}, \mathrm{c}, \mathrm{f}$ & & $\begin{array}{c}a, b, c, f, \\
g, j\end{array}$ & $\begin{array}{l}\text { Red Lights } \\
\text { going west on } \\
\text { Main is too } \\
\text { short. Buses }\end{array}$ & $\begin{array}{l}\text { more } \\
\text { than } \\
\text { twice } \\
\text { per day }\end{array}$ & $\mathrm{c}, \mathrm{e}, \mathrm{g}$ & $\begin{array}{l}2-4 \\
\min \end{array}$ & 47906 & \\
\hline 39 & $\begin{array}{c}\text { At McCarty } \\
\text { Ln. and CR } \\
500 \mathrm{E}\end{array}$ & $\mathrm{f}$ & & $\mathrm{b}, \mathrm{h}$ & & $\begin{array}{l}\text { more } \\
\text { than } \\
\text { twice } \\
\text { per day }\end{array}$ & $\mathrm{d}, \mathrm{e}, \mathrm{g}, \mathrm{h}$ & $\begin{array}{c}\text { less } \\
\text { than } \\
2 \mathrm{~min}\end{array}$ & 47905 & \\
\hline 40 & $\begin{array}{l}\text { Northweste } \\
\text { rn Ave and } \\
\text { Cherry Ln. }\end{array}$ & $\mathrm{f}, \mathrm{i}$ & $\begin{array}{c}\text { Saw aftermath } \\
\text { of wreck }\end{array}$ & $g, j$ & $\begin{array}{l}\text { No left turn } \\
\text { signal }\end{array}$ & $\begin{array}{c}\text { once } \\
\text { per day }\end{array}$ & $\mathrm{g}$ & $\begin{array}{l}2-4 \\
\min \end{array}$ & 47906 & \\
\hline 41 & \begin{tabular}{|c} 
At \\
Northweste \\
rn Ave and \\
Lindberg \\
Rd.
\end{tabular} & $\mathrm{a}, \mathrm{b}, \mathrm{f}, \mathrm{h}$ & & $\underset{j}{a, b, d, f,}$ & All torn up & $\begin{array}{c}3-5 \\
\text { times } \\
\text { per } \\
\text { week }\end{array}$ & $\begin{array}{c}a, e, f, h, \\
i\end{array}$ & $\begin{array}{l}6-8 \\
\min \end{array}$ & 47906 & \\
\hline 42 & $\begin{array}{c}\text { At } \\
\text { Northweste } \\
\text { rn Ave and } \\
\text { Lindberg } \\
\text { Rd. }\end{array}$ & $\mathrm{a}, \mathrm{f}$ & & $\mathrm{b}$ & $\begin{array}{c}\text { Drivers } \\
\text { running red } \\
\text { lights on } \\
\text { Northwestern }\end{array}$ & $\begin{array}{c}3-5 \\
\text { times } \\
\text { per } \\
\text { week }\end{array}$ & d, e, f, g & $\begin{array}{l}4-6 \\
\min \end{array}$ & 47906 & \\
\hline
\end{tabular}


Table B.10. Survey Results - 5B

\begin{tabular}{|c|c|c|c|c|c|c|c|c|c|c|}
\hline ID & Location & M & F & Age & Q9 A & Q9 B & Q9 C & Q9 D & Q9 E & Comment \\
\hline 35 & $\begin{array}{l}\text { At I-65 and } \\
\quad \text { SR } 43\end{array}$ & $\mathrm{Y}$ & & $56-65 \mid$ & $\mathrm{a}$ & $\mathrm{a}$ & $\mathrm{a}$ & c & b & $\begin{array}{l}\text { Higway } 43 \text { south should be a gateway with median plantings.It should } \\
\text { connect } 52 \text { better than it does. Possible a clover leaf on } 52 \text { and } 43 \text {. }\end{array}$ \\
\hline 36 & $\begin{array}{l}\text { At I-65 and } \\
\quad \text { SR } 43\end{array}$ & $\mathrm{Y}$ & & $56-65 \mid$ & $\mathrm{a}$ & $\mathrm{a}$ & $\mathrm{a}$ & $\mathrm{a}$ & $\mathrm{a}$ & $\begin{array}{l}\text { Turning Southbound on } 43 \text { is the problem. The concrete dividing } \\
\text { barriers make it impossible to see existing S.B. traffic on } 43 \text { except for } \\
\text { trucks or "tall" traffic. I frequently turn N.B. to avoid this problem even } \\
\text { though turning S.B. is closer to home. }\end{array}$ \\
\hline 37 & $\begin{array}{l}\text { At Kossuth St. } \\
\text { and 26th St. }\end{array}$ & & $\mathrm{Y}$ & |26-35 & $\mathrm{a}$ & $\mathrm{a}$ & $\mathrm{a}$ & $\mathrm{a}$ & $\mathrm{a}$ & \\
\hline 38 & $\begin{array}{l}\text { At Main St. } \\
\text { and 3rd St. }\end{array}$ & $\mathrm{Y}$ & & $36-45$ & $\mathrm{a}$ & $\mathrm{a}$ & $\mathrm{a}$ & $\mathrm{a}$ & $\mathrm{a}$ & $\begin{array}{l}\text { It would be nice not to be required to start over with the maps there are } \\
\text { four intersections around one block that are all bad. I am required to } \\
\text { enter them one at a time. (By the way, the intersections are: 3rd \& } \\
\text { Main, 3rd \& Ferry, 4th \& Main, 4th \& Ferry. Cars repeatedly run the } \\
\text { red lights at high speed traveling east and west trying to make both } \\
\text { lights. }\end{array}$ \\
\hline 39 & $\begin{array}{l}\text { At McCarty } \\
\text { Ln. and CR } \\
500 \mathrm{E}\end{array}$ & & $\mathrm{Y}$ & $|36-45|$ & $\mathrm{a}$ & $\mathrm{a}$ & $\mathrm{a}$ & $\mathrm{a}$ & 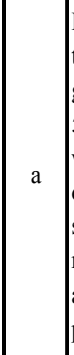 & $\begin{array}{l}\text { Due to increase in traffic from Meijer and Subaru and Caterpillar } \\
\text { trucking plant, opening of } 350 \mathrm{~S} \text { and the 4-laning of McCarty, there is } \\
\text { gobs more traffic at this intersection and on } 500 \mathrm{E} \text {. Turning north onto } \\
500 \text { from McCarty is difficult, especially during rush hours. I have } \\
\text { witnessed people zooming straight across } 500 \text { from McCarty to the } \\
\text { deadend street, turning around to make a right onto } 500 \text {. They do this } \\
\text { so not to have to wait their turn to turn left. (Don't have } \\
\text { recommendation on how to plan for idiots.) Especially once the woods } \\
\text { are made into a park, a light will be needed at this intersection. More } \\
\text { patrolling of speeds on } 500 \text { needed. Many go lots faster than } 50 \mathrm{mph} \text {. }\end{array}$ \\
\hline 40 & $\begin{array}{c}\text { At } \\
\text { Northwestern } \\
\text { Ave and } \\
\text { Cherry Ln. }\end{array}$ & & $\mathrm{Y}$ & $36-45 \mid$ & c & $\mathrm{c}$ & $\mathrm{a}$ & c & b & $\begin{array}{l}\text { The intersection I was concerned about was extremely hard to locate on } \\
\text { the maps - even though it is on a major artery through West Lafayette. }\end{array}$ \\
\hline 41 & $\begin{array}{c}\text { At } \\
\text { Northwestern } \\
\text { Ave and } \\
\text { Lindberg Rd. }\end{array}$ & Y & & $36-45$ & $\mathrm{a}$ & $\mathrm{a}$ & $\mathrm{a}$ & $\mathrm{a}$ & $\mathrm{a}$ & \\
\hline 42 & $\begin{array}{c}\text { At } \\
\text { Northwestern } \\
\text { Ave and } \\
\text { Lindberg Rd. }\end{array}$ & Y & & $65+$ & $\mathrm{a}$ & $\mathrm{a}$ & $\mathrm{a}$ & $\mathrm{a}$ & b & $\begin{array}{l}\text { THere would be no need to estimate extra time to avoid intersection if } \\
\text { drivers would not speed and try to beat the signal. The traffic at this } \\
\text { intersection is not excessive in my opinion. }\end{array}$ \\
\hline
\end{tabular}


Table B.11. Survey Results - 6A

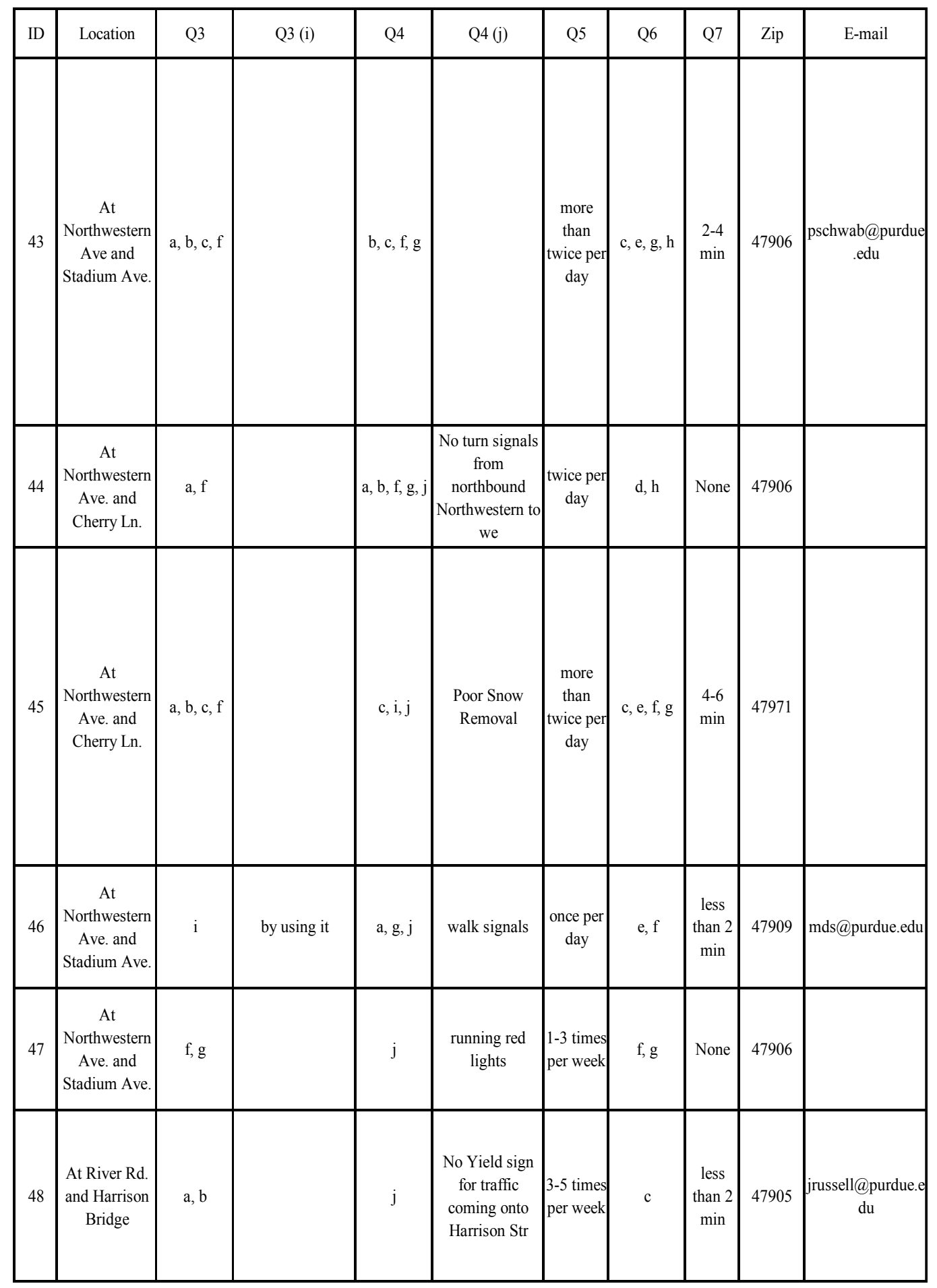


Table B.12. Survey Results - 6B

\begin{tabular}{|c|c|c|c|c|c|c|c|c|c|c|}
\hline ID & Location & M & F & Age & Q9 A & Q9 B & Q9 C & Q9 D & Q9 E & Comment \\
\hline 43 & $\begin{array}{l}\text { At } \\
\text { Northwestern } \\
\text { Ave and } \\
\text { Stadium Ave. }\end{array}$ & $\mathrm{Y}$ & & $\mid 46-55$ & $\mathrm{a}$ & $\mathrm{a}$ & $\mathrm{a}$ & $\mathrm{a}$ & 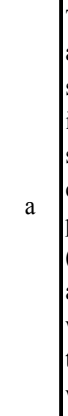 & $\begin{array}{l}\text { This intersection is a total nightmare. The pedestrian traffic is always } \\
\text { at risk for two reasons: 1) the very long light rotations coupled with the } \\
\text { sequence of turn arrows makes the pedestrians impatient -- jaywalking } \\
\text { is rampant and bogs down traffic. This applies to students and non- } \\
\text { students alike. 2) Right turn on red is a hazard to pedestrians who are } \\
\text { crossing legally. The safest way to cross this intersection as a } \\
\text { pedestrian is to avoid it! Dozens of people cross half a block away } \\
\text { (jaywalking) so that they only have to deal with one aspect of traffic at } \\
\text { a time. SOLUTION: Pedestrian crossing lights should come on only } \\
\text { when all traffic has a red light, and all pedestrian light should be lit at } \\
\text { the same time. (That is, all traffic is stopped during pedestrian crossing } \\
\text { when all pedestrians are crossing in all directions at once.) }\end{array}$ \\
\hline 44 & $\begin{array}{l}\text { At } \\
\text { Northwestern } \\
\text { Ave. and } \\
\text { Cherry Ln. }\end{array}$ & $\mathrm{Y}$ & & $36-45$ & $\mathrm{a}$ & b & $\mathrm{b}$ & c & c & \\
\hline 45 & $\begin{array}{l}\text { At } \\
\text { Northwestern } \\
\text { Ave. and } \\
\text { Cherry Ln. }\end{array}$ & $\mathrm{Y}$ & & $36-45$ & $\mathrm{c}$ & $\mathrm{b}$ & $\mathrm{a}$ & $\mathrm{b}$ & 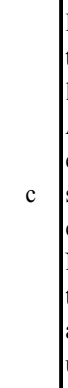 & $\begin{array}{l}\text { Left turns from Northwestern Ave. severely complicate rush hour } \\
\text { traffic. Traffic is always backed up at Cherry Lane in the Westbound } \\
\text { lanes due to vehicles turning left (West) onto Cherry Lane. Stopping } \\
\text { ALL left turns during rush hours (7-9AM and 4-6PM) would be } \\
\text { extremely helpful in keeping traffic moving on Northwestern. Also, } \\
\text { snow removal in West Lafayette is pathetic, Northwestern Ave. is no } \\
\text { exception. Road crews MUST salt roads as the snow falls on hills like } \\
\text { Northwestern Ave. in the Cherry lane area. When the salt crews wait } \\
\text { too long, the result is numerous slideoffs and accidents. It's truly } \\
\text { astounding that the powers that be in the Lafayette area don't } \\
\text { understand this. }\end{array}$ \\
\hline 46 & $\begin{array}{l}\text { At } \\
\text { Northwestern } \\
\text { Ave. and } \\
\text { Stadium Ave. }\end{array}$ & $\mathrm{Y}$ & & $46-55$ & b & b & $\mathrm{b}$ & c & c & $\begin{array}{l}\text { Ahh, State and Northwestern. The worst design around for } \\
\text { crosswalks. There is not enough room in this puny box for me to tell } \\
\text { you all my complaints I'll send them to Brian DeSalle. }\end{array}$ \\
\hline 47 & $\begin{array}{l}\text { At } \\
\text { Northwestern } \\
\text { Ave. and } \\
\text { Stadium Ave. }\end{array}$ & Y & & $65+$ & $\mathrm{a}$ & $\mathrm{a}$ & $\mathrm{a}$ & $\mathrm{a}$ & $\mathrm{b}$ & $\begin{array}{l}\text { This is another case where the road and signals are not at fault. Drivers } \\
\text { cannot wait. Perhaps what is needed is a effective educational effort } \\
\text { emphasizing safe driving or cameras at some intersections. Publish } \\
\text { pictures and names in the newspaper. }\end{array}$ \\
\hline 48 & $\begin{array}{l}\text { At River Rd. } \\
\text { and Harrison } \\
\text { Bridge }\end{array}$ & $\mathrm{Y}$ & & $56-65$ & a & a & $\mathrm{a}$ & a & $\mathrm{a}$ & $\begin{array}{l}\text { I was involved in near accident and driver coming onto Harrison } \\
\text { Bridge from North River Road scolded me and told me that he had the } \\
\text { right of way. Neither road has a yield sign, but I thought oncoming } \\
\text { traffic should yield. I could not get over to the left lane because of } \\
\text { other traffic. I have also observed other near misses because of the } \\
\text { lack of a yield sign. }\end{array}$ \\
\hline
\end{tabular}


Table B.13. Survey Results - 7A

\begin{tabular}{|c|c|c|c|c|c|c|c|c|c|c|}
\hline ID & Location & Q3 & Q3 (i) & Q4 & Q4 (j) & Q5 & Q6 & Q7 & Zip & E-mail \\
\hline 49 & $\begin{array}{c}\text { At Sagamore } \\
\text { Pkwy and } \\
\text { Creasy/Brady } \\
\text { Ln. }\end{array}$ & $a, f$ & & $\mathrm{~b}$ & & $\begin{array}{c}\text { twice per } \\
\text { day }\end{array}$ & $\mathrm{e}, \mathrm{g}, \mathrm{h}$ & $\begin{array}{l}2-4 \\
\min \end{array}$ & 47909 & \\
\hline 50 & $\begin{array}{c}\text { At Sagamore } \\
\text { Pkwy and } \\
\text { Creasy/Brady } \\
\text { Ln. }\end{array}$ & $\mathrm{f}$ & & $\mathrm{b}, \mathrm{j}$ & $\begin{array}{l}\text { People leaving } \\
\text { stoplight before } \\
\text { it turns green in }\end{array}$ & $\begin{array}{c}\text { more } \\
\text { than } \\
\text { twice per } \\
\text { day }\end{array}$ & $\mathrm{f}, \mathrm{g}, \mathrm{h}, \mathrm{i}$ & $\begin{array}{l}4-6 \\
\min \end{array}$ & 47909 & \\
\hline 51 & $\begin{array}{c}\text { At Sagamore } \\
\text { Pkwy and } \\
\text { Creasy/Brady } \\
\text { Ln. }\end{array}$ & $\mathrm{f}, \mathrm{i}$ & $\begin{array}{c}\text { many people run } \\
\text { red lights to avoid } \\
\text { waiting }\end{array}$ & $g, j$ & $\begin{array}{l}\text { timing of } \\
\text { signals is } \\
\text { terrible at } \\
\text { certain times of }\end{array}$ & $\begin{array}{l}1-3 \text { times } \\
\text { per week }\end{array}$ & $\mathrm{h}$ & $\begin{array}{l}2-4 \\
\min \end{array}$ & 47905 & \\
\hline 52 & $\begin{array}{c}\text { At Sagamore } \\
\text { Pkwy and } \\
\text { Creasy/Brady } \\
\text { Ln. }\end{array}$ & $\mathrm{a}$ & & $\mathrm{j}$ & $\begin{array}{c}\text { two lanes } \\
\text { narrowing to } \\
\text { one on a curve }\end{array}$ & $\begin{array}{c}\text { more } \\
\text { than } \\
\text { twice per } \\
\text { day }\end{array}$ & $\mathrm{c}, \mathrm{d}, \mathrm{f}, \mathrm{g}$ & $\begin{array}{l}8-10 \\
\min \end{array}$ & 47909 & \\
\hline 53 & $\begin{array}{c}\text { At Sagamore } \\
\text { Pkwy and } \\
\text { Creasy/Brady } \\
\text { Ln. }\end{array}$ & $\mathrm{a}, \mathrm{f}, \mathrm{i}$ & Drive it every day & $\mathrm{b}, \mathrm{g}$ & & $\begin{array}{c}\text { twice per } \\
\text { day }\end{array}$ & $\mathrm{c}, \mathrm{h}$ & $\begin{array}{l}8-10 \\
\min \end{array}$ & 47905 & sgifford@gte.net \\
\hline 54 & $\begin{array}{c}\text { At Sagamore } \\
\text { Pkwy and } \\
\text { Creasy/Brady } \\
\text { Ln. }\end{array}$ & $\mathrm{a}, \mathrm{c}, \mathrm{f}$ & & $\mathrm{b}, \mathrm{c}, \mathrm{g}$ & & $\begin{array}{c}\text { more } \\
\text { than } \\
\text { twice per } \\
\text { day }\end{array}$ & $\mathrm{c}, \mathrm{e}, \mathrm{f}, \mathrm{g}$ & $\begin{array}{l}6-8 \\
\min \end{array}$ & 47909 & \\
\hline 55 & $\begin{array}{l}\text { At Sagamore } \\
\text { Pkwy and } \\
\text { Greenbush }\end{array}$ & $\mathrm{f}$ & & g & & $\begin{array}{c}\text { more } \\
\text { than } \\
\text { twice per } \\
\text { day }\end{array}$ & $\mathrm{c}, \mathrm{e}, \mathrm{g}$ & $\begin{array}{c}\text { less } \\
\text { than } 2 \\
\text { min }\end{array}$ & 47905 & $\begin{array}{c}\text { k3mkoors@home } \\
\text {.com }\end{array}$ \\
\hline
\end{tabular}


Table B.14. Survey Results - 7B

\begin{tabular}{|c|c|c|c|c|c|c|c|c|c|c|}
\hline ID & Location & M & F & Age & Q9 A & Q9 B & Q9 C & Q9 D & Q9 E & Comment \\
\hline 49 & $\begin{array}{l}\text { At Sagamore } \\
\text { Pkwy and } \\
\text { Creasy/Brady } \\
\text { Ln. }\end{array}$ & & $\mathrm{Y}$ & $|56-65|$ & $\mathrm{a}$ & $\mathrm{a}$ & $\mathrm{a}$ & $\mathrm{a}$ & $\mathrm{b}$ & $\begin{array}{l}\text { If you are traveling West on Creasy and have to stop for traffic light at } \\
\text { creasy \& } 52 \text { be prepared for a drag race. There are two lanes going } \\
\text { west onto brady la. one is actually an entrance lane to the County } \\
\text { highway department. Brady lane funnels down to single lane from } \\
\text { creasy and there is nowhere for cars in outer lane to go except for } \\
\text { squeezing into traffic. Have seen many near misses. }\end{array}$ \\
\hline 50 & $\begin{array}{c}\text { At Sagamore } \\
\text { Pkwy and } \\
\text { Creasy/Brady } \\
\text { Ln. }\end{array}$ & & $\mathrm{Y}$ & $|16-25|$ & $\mathrm{a}$ & $\mathrm{a}$ & $\mathrm{a}$ & $\mathrm{a}$ & $\mathrm{a}$ & \\
\hline 51 & $\begin{array}{l}\text { At Sagamore } \\
\text { Pkwy and } \\
\text { Creasy/Brady } \\
\text { Ln. }\end{array}$ & $\mathrm{Y}$ & & $16-25$ & c & b & $\mathrm{a}$ & $\mathrm{b}$ & 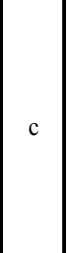 & $\begin{array}{l}\text { If someone is driving on Brady Lane (which turns into Creasy Lane at } \\
\text { this intersection), they are only given a few seconds of green. When } \\
\text { the signal turns yellow and red, cars are still going so they won't have } \\
\text { to wait for a long time to get only a few seconds of green again. This } \\
\text { is a very dangerous situation, and it won't be long before someone gets } \\
\text { seriously injured or killed. The map is not correct for these roads. They } \\
\text { have been changed, but the map is not updated. }\end{array}$ \\
\hline 52 & $\begin{array}{l}\text { At Sagamore } \\
\text { Pkwy and } \\
\text { Creasy/Brady } \\
\text { Ln. }\end{array}$ & $\mathrm{Y}$ & & $|56-65|$ & $\mathrm{a}$ & $\mathrm{a}$ & b & $\mathrm{a}$ & $\mathrm{b}$ & $\begin{array}{l}\text { I feel the map is outdated. Creasy Lane and Brady Lane meet at } \\
\text { Sagamore Parkway and Ross road does not go through as the map } \\
\text { depicts it. }\end{array}$ \\
\hline 53 & $\begin{array}{l}\text { At Sagamore } \\
\text { Pkwy and } \\
\text { Creasy/Brady } \\
\text { Ln. }\end{array}$ & $\mathrm{Y}$ & & $|46-55|$ & $\mathrm{a}$ & $\mathrm{a}$ & $\mathrm{a}$ & $\mathrm{a}$ & $\mathrm{a}$ & $\begin{array}{l}\text { I sat at the Turn light for } 1 \text { min \& } 20 \text { seconds Sunday morning waiting } \\
\text { to turn left on Brady Ln. The Light on } 52 @ \text { Brady/ Creasy Ln. stays } \\
\text { green even when there is no traffic on } 52 \text {. People are impatient and } \\
\text { make their turns on red anyway. Besides, I should not have to set at } \\
\text { any red light when there is no traffic for the green light showing. }\end{array}$ \\
\hline 54 & $\begin{array}{l}\text { At Sagamore } \\
\text { Pkwy and } \\
\text { Creasy/Brady } \\
\text { Ln. }\end{array}$ & & $\mathrm{Y}$ & $\mid 26-35$ & $\mathrm{a}$ & a & $\mathrm{a}$ & $\mathrm{b}$ & 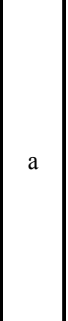 & $\begin{array}{l}\text { Yet another accident this morning! I don't know why there is no } \\
\text { turning arrow from Brady/Creasy onto } 52 \text {. Too many people turning } \\
\text { left to go N on Creasy from } 52 \text { after their arrow has disappeared. I'm } \\
\text { not sure if they've changed the pattern there, but the last time I checked } \\
\text { there is no left turn w/o an arrow; the light turns red instead. Too many } \\
\text { semi-trucks blowing through the light on } 52 \text { (but hey, at least they } \\
\text { blast their horns to let you know they're not going to stop). I have tried } \\
\text { to find a way around, but there really is no good way to get from where } \\
\text { I live to Ivy Tech. }\end{array}$ \\
\hline 55 & $\begin{array}{c}\text { At Sagamore } \\
\text { Pkwy and } \\
\text { Greenbush }\end{array}$ & $\mathrm{Y}$ & & $46-55$ & a & $\mathrm{a}$ & a & $\mathrm{a}$ & c & $\begin{array}{l}\text { On Item 4, there needs to be a way to explain what makes the unsafe } \\
\text { condition unsafe. For example in this case, the high volume of semi } \\
\text { trucks on Sagamore Pkwy leads to more vehicles running red lights } \\
\text { because the trucks don't want to stop, and the cars immediately behind } \\
\text { them can't see the stop light over the truck. So, those cars blindly } \\
\text { follow the trucks through the intersection. Sometimes I've seen } 3 \text { cars } \\
\text { follow a single truck through a red light. }\end{array}$ \\
\hline
\end{tabular}


Table B.15. Survey Results - 8A

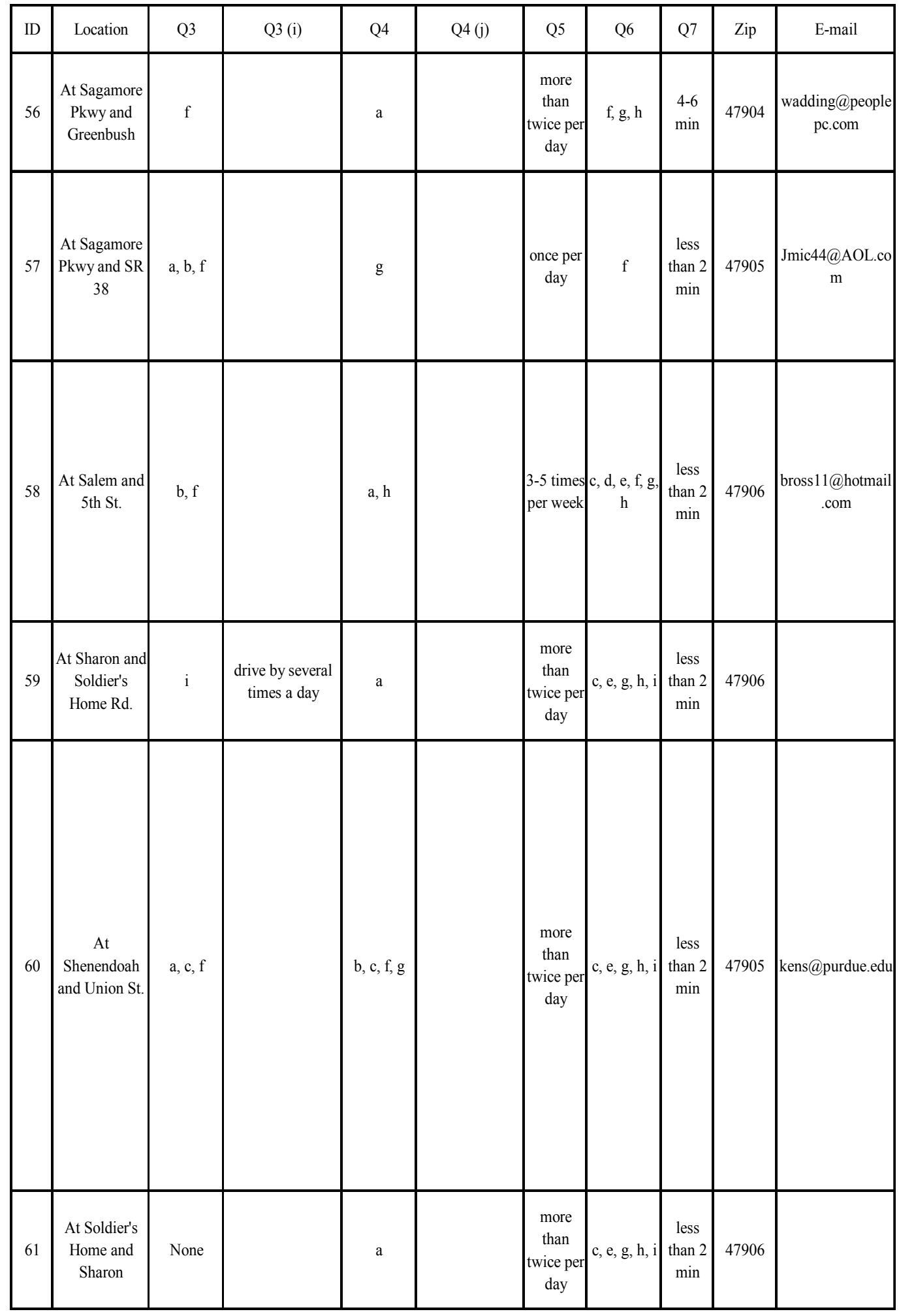


Table B.16. Survey Results - 8B

\begin{tabular}{|c|c|c|c|c|c|c|c|c|c|c|}
\hline ID & Location & M & $\mathrm{F}$ & Age & Q9 A & Q9 B & Q9 C & Q9 D & Q9 E & Comment \\
\hline 56 & $\begin{array}{l}\text { At Sagamore } \\
\text { Pkwy and } \\
\text { Greenbush }\end{array}$ & & $\mathrm{Y}$ & $|46-55|$ & $\mathrm{a}$ & $\mathrm{a}$ & $\mathrm{a}$ & $\mathrm{a}$ & $\mathrm{a}$ & $\begin{array}{l}\text { When at the stop sign waiting to turn on Greenbush you can't see } \\
\text { unless you are just about out in the road due to trees put in by the road. } \\
\text { Not a very safe condition at all. }\end{array}$ \\
\hline 57 & $\begin{array}{l}\text { At Sagamore } \\
\text { Pkwy and SR } \\
38\end{array}$ & $\mathrm{Y}$ & & $65+$ & $\mathrm{a}$ & $\mathrm{a}$ & $\mathrm{a}$ & c & $\mathrm{b}$ & $\begin{array}{l}\text { At certain times the turn signal to turn from } 38 \text { headed toward town } \\
\text { onto Sagamore south bound is timed so that one vehicle is lucky to get } \\
\text { thru. I have seen as many as six go thru on red light. The back up has } \\
\text { stretched to the light at K mart entrance on } 38 \text {. I have heard that } \\
\text { several turn signals on Sagamore has also been changed as this one is. } \\
\text { PS. I drive professionally and have not seen any other city with this } \\
\text { kind of "Shoot thru" turn signal. }\end{array}$ \\
\hline 58 & $\begin{array}{l}\text { At Salem and } \\
\text { 5th St. }\end{array}$ & Y & & $26-35$ & $\mathrm{a}$ & $\mathrm{a}$ & $\mathrm{a}$ & c & 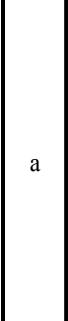 & $\begin{array}{l}\text { The questions should ask more for suggestions. It is one of only } 2 \\
\text { ways to cross the bridge. The other would involve going out of my } \\
\text { way and around the block. The danger is more from the people } \\
\text { wanting to cross the road I usually use. I have had to cross or turn onto } \\
\text { Salem from 5th or 6th and it is very unsafe. It should be a one way } \\
\text { street going away from Salem. They have just built these roads and it } \\
\text { shocks me nobody noticed how it is impossible to see past the bar } \\
\text { when you want to cross Salem or turn onto the road and changing the } \\
\text { speedlimit from an already slow } 25 \text { or enforcing it better won't help. }\end{array}$ \\
\hline 59 & $\begin{array}{l}\text { At Sharon and } \\
\text { Soldier's } \\
\text { Home Rd. }\end{array}$ & & $\mathrm{Y}$ & $36-45$ & $\mathrm{a}$ & $\mathrm{a}$ & $\mathrm{a}$ & $\mathrm{a}$ & $\mathrm{a}$ & $\begin{array}{l}\text { School zone flashing light and sign block the view when turning left } \\
\text { from Sharon to Soldier's Home. It's especially dangerous now, with } \\
\text { the Montisorri School, as traffic is increased. }\end{array}$ \\
\hline 60 & $\begin{array}{c}\text { At } \\
\text { Shenendoah } \\
\text { and Union St. }\end{array}$ & $\mathrm{Y}$ & & $46-55$ & $\mathrm{a}$ & $\mathrm{a}$ & $\mathrm{a}$ & $\mathrm{a}$ & 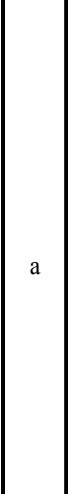 & $\begin{array}{l}\text { Your map is out of date. Shenendoah now extends across Union all } \\
\text { the way to State Road } 26 \text {. } \\
\text { This is a dangerous intersection particularly at morning and afternoon } \\
\text { rush hour. Traffic is very heavy on Union at these times and drivers on } \\
\text { Shenandoah have to dart across } 4 \text { lanes to continue on Shenandoah. } \\
\text { This is a 2-way stop sign on Shenandoah, Union doesn't stop. Union } \\
\text { drivers regularly exceed speed limit. There are two city parks within } 3 \\
\text { blocks east and west of this intersection and kids cross Union to get } \\
\text { there. New elderly housing subdivision between Union and St Rd } 26 \\
\text { and new Target has increased traffic on Shenandoah. I live one block } \\
\text { from this intersection and routinely hear tires squealing, engines } \\
\text { accelerating, and yes, smashing cars. Had another accident there last } \\
\text { night. This intersection desperately needs a stop light, like the one at } \\
\text { 36th \& Union, before a neighbor kid going to a park gets killed. }\end{array}$ \\
\hline 61 & $\begin{array}{l}\text { At Soldier's } \\
\text { Home and } \\
\text { Sharon }\end{array}$ & & $\mathrm{Y}$ & $36-45$ & $\mathrm{a}$ & $\mathrm{a}$ & $\mathrm{a}$ & $\mathrm{a}$ & $\mathrm{a}$ & $\begin{array}{l}\text { Difficult to see to turn left from Sharon to Soldier's home due to school } \\
\text { signs, etc. on corner. Much increased traffic due to Montesorri school. }\end{array}$ \\
\hline
\end{tabular}


Table B.17. Survey Results - 9A

\begin{tabular}{|c|c|c|c|c|c|c|c|c|c|c|}
\hline ID & Location & Q3 & Q3 (i) & Q4 & Q4 (j) & Q5 & Q6 & Q7 & Zip & E-mail \\
\hline 62 & $\begin{array}{c}\text { At South } \\
\text { River Rd. and } \\
\text { Harrison } \\
\text { Bridge }\end{array}$ & $a, b, f$ & & $a, b, j$ & $\begin{array}{c}\text { south bound } \\
\text { traffic is unable } \\
\text { to see light from } \\
\text { fa }\end{array}$ & $\begin{array}{c}\text { more } \\
\text { than } \\
\text { twice per } \\
\text { day }\end{array}$ & $\begin{array}{c}\text { c, d, e, f, g, } \\
\text { h, i }\end{array}$ & $\begin{array}{l}4-6 \\
\min \end{array}$ & 47906 & $\begin{array}{c}\text { ikking@earthlink } \\
\text {.net }\end{array}$ \\
\hline 63 & $\begin{array}{l}\text { At South St. } \\
\text { and 9th St. }\end{array}$ & $\mathrm{f}$ & & $\mathrm{g}$ & & $\begin{array}{c}\text { once per } \\
\text { day }\end{array}$ & $\mathrm{c}$ & $\begin{array}{c}\text { less } \\
\text { than } 2 \\
\text { min }\end{array}$ & 47960 & \\
\hline 64 & $\begin{array}{l}\text { At South St. } \\
\text { and Main St }\end{array}$ & $\mathrm{a}, \mathrm{c}, \mathrm{f}$ & & $b, c, g, j$ & $\begin{array}{c}5 \text { POINTS } \\
\text { INTERSECTIO } \\
\text { N/LEFT TURN } \\
\text { LIGHT ON } \\
\text { EAST BOUN }\end{array}$ & $\begin{array}{c}\text { more } \\
\text { than } \\
\text { twice per } \\
\text { day }\end{array}$ & e, f, g, h, i & $\begin{array}{c}\text { less } \\
\text { than } 2 \\
\text { min }\end{array}$ & 47905 & $\begin{array}{c}\text { SLOTH273@AO } \\
\text { L.COM }\end{array}$ \\
\hline 65 & $\begin{array}{l}\text { At South St. } \\
\text { and Main St }\end{array}$ & $a, b, g$ & & $\mathrm{a}$ & & $\begin{array}{c}\text { less than } \\
\text { once per } \\
\text { week }\end{array}$ & $\mathrm{f}$ & $\begin{array}{l}4-6 \\
\min \end{array}$ & 47906 & \\
\hline 66 & $\begin{array}{c}\text { At SR } 25 \text { and } \\
\text { Access rd. E } \\
\text { of RR Bridge }\end{array}$ & $\mathrm{b}, \mathrm{f}$ & & $\mathrm{j}$ & $\begin{array}{c}\text { lines in wrong } \\
\text { location }\end{array}$ & $\begin{array}{c}\text { once per } \\
\text { day }\end{array}$ & d & $\begin{array}{c}\text { less } \\
\text { than } 2 \\
\text { min }\end{array}$ & 47904 & $\begin{array}{c}\text { swan.swan@gte. } \\
\text { net }\end{array}$ \\
\hline 67 & $\begin{array}{c}\text { At SR } 25 \text { and } \\
\text { Beck Ln. }\end{array}$ & $a, f$ & & $\mathrm{~b}, \mathrm{~h}$ & & $\begin{array}{l}3-5 \text { times } \\
\text { per week }\end{array}$ & $\mathrm{d}, \mathrm{g}$ & $\begin{array}{l}2-4 \\
\min \end{array}$ & 47909 & \\
\hline 68 & $\begin{array}{c}\text { At SR } 25 \text { and } \\
\text { Beck Ln. }\end{array}$ & $\mathrm{a}, \mathrm{c}, \mathrm{f}$ & & $\mathrm{c}$ & & $\begin{array}{c}\text { once per } \\
\text { day }\end{array}$ & $\mathrm{c}, \mathrm{g}$ & $\begin{array}{l}2-4 \\
\min \end{array}$ & 47909 & \\
\hline 69 & $\begin{array}{c}\text { At SR } 25 \text { and } \\
\text { CR } 300 \mathrm{~S}\end{array}$ & $\mathrm{i}$ & $\begin{array}{l}\text { Long wait for } \\
\text { traffic }\end{array}$ & None & & $\begin{array}{c}\text { more } \\
\text { than } \\
\text { twice per } \\
\text { day }\end{array}$ & d & $\begin{array}{c}6-8 \\
\min \end{array}$ & $\begin{array}{c}47992- \\
9282\end{array}$ & $\begin{array}{c}\text { Tjhughel@aoool. } \\
\text { com }\end{array}$ \\
\hline 70 & $\begin{array}{c}\text { At SR } 25 \text { and } \\
\text { US } 231\end{array}$ & $\mathrm{f}, \mathrm{i}$ & $\begin{array}{l}\text { frustration with } \\
\text { signal lights }\end{array}$ & $\mathrm{g}$ & & $\begin{array}{c}\text { less than } \\
\text { once per } \\
\text { week }\end{array}$ & $\mathrm{f}$ & $\begin{array}{c}\text { less } \\
\text { than } 2 \\
\text { min }\end{array}$ & 47909 & $\begin{array}{c}\text { ddnaylor@purdue } \\
\text {.edu }\end{array}$ \\
\hline
\end{tabular}


Table B.18. Survey Results - 9B

\begin{tabular}{|c|c|c|c|c|c|c|c|c|c|c|}
\hline ID & Location & M & $\mathrm{F}$ & Age & Q9 A & Q9 B & Q9 C & Q9 D & Q9 E & Comment \\
\hline 62 & $\begin{array}{l}\text { At South } \\
\text { River Rd. and } \\
\text { Harrison } \\
\text { Bridge }\end{array}$ & & $\mathrm{Y}$ & $36-45$ & b & b & b & c & c & $\begin{array}{l}\text { Need more options on the How is it unsafe. I would like to see an area } \\
\text { for suggested changes or what would help make this sight safer. }\end{array}$ \\
\hline 63 & $\begin{array}{l}\text { At South St. } \\
\text { and 9th St. }\end{array}$ & Y & & $46-55$ & $\mathrm{a}$ & $\mathrm{a}$ & $\mathrm{a}$ & b & $\mathrm{a}$ & $\begin{array}{l}\text { There needs to be a right turn arrow onto South St. from southbound } \\
\text { 9th St. Northbound 9th St. traffic runs red light to make turn to South } \\
\text { St. impossible without parking in intersection and waiting for traffic to } \\
\text { pass. }\end{array}$ \\
\hline 64 & $\begin{array}{l}\text { At South St. } \\
\text { and Main St }\end{array}$ & Y & & $36-45$ & $\mathrm{a}$ & $\mathrm{a}$ & $\mathrm{a}$ & $\mathrm{a}$ & $\mathrm{a}$ & \\
\hline 65 & $\begin{array}{l}\text { At South St. } \\
\text { and Main St }\end{array}$ & Y & & $|16-25|$ & a & b & $\mathrm{a}$ & $\mathrm{a}$ & $\mathrm{a}$ & \\
\hline 66 & $\begin{array}{l}\text { At SR } 25 \text { and } \\
\text { Access rd. E } \\
\text { of RR Bridge }\end{array}$ & $\mathrm{Y}$ & & $46-55$ & $\mathrm{a}$ & $\mathrm{a}$ & $\mathrm{a}$ & $\mathrm{a}$ & $\mathrm{a}$ & $\begin{array}{l}\text { On North bound } 25 \text { the lines were painted to follow the asphalt and not } \\
\text { the actual lane. When in the right lane, if one stays to the left of the } \\
\text { centerline, the line of travel can take the driver into the curb. The line } \\
\text { on this curve is about ten feet too far to the right. }\end{array}$ \\
\hline 67 & $\begin{array}{l}\text { At SR } 25 \text { and } \\
\text { Beck Ln. }\end{array}$ & & Y & $|36-45|$ & $\mathrm{a}$ & $\mathrm{a}$ & c & $\mathrm{a}$ & $\mathrm{a}$ & \\
\hline 68 & $\begin{array}{l}\text { At SR } 25 \text { and } \\
\text { Beck Ln. }\end{array}$ & & $\mathrm{Y}$ & $|46-55|$ & $\mathrm{a}$ & $\mathrm{a}$ & $\mathrm{a}$ & $\mathrm{a}$ & $\mathrm{a}$ & \\
\hline 69 & $\begin{array}{c}\text { At SR } 25 \text { and } \\
\text { CR } 300 \mathrm{~S}\end{array}$ & Y & & $65+$ & $\mathrm{a}$ & $\mathrm{a}$ & $\mathrm{a}$ & $\mathrm{a}$ & $\mathrm{a}$ & $\begin{array}{l}\text { A stop light is badly needed at the corner of SR } 25 \mathrm{~W} \text { and } 300 \mathrm{~S} \text {. The } \\
\text { construction of several new homes on } 300 \mathrm{~S} \text { has added to the traffic at } \\
\text { this intersection. }\end{array}$ \\
\hline 70 & $\begin{array}{l}\text { At SR } 25 \text { and } \\
\text { US } 231\end{array}$ & Y & & $|26-35|$ & $\mathrm{a}$ & $\mathrm{a}$ & $\mathrm{a}$ & c & c & $\begin{array}{l}\text { I was curious about this site; wanted to check it out and make a note } \\
\text { about an annoying (not necessarily unsafe) intersection...perhaps more } \\
\text { for my benefit than yours. Hope that's OK. The questions/responses } \\
\text { are OK if you're strictly doing "unsafe" places, rather than including } \\
\text { "annoying." By the way, the reason this intersection is frustrating at } \\
\text { times is the "left turn on arrow only" sign. If you're on } 25 \text { needing to } \\
\text { turn left on } 231 \text { South, you can't go left on the green light (even with no } \\
\text { approaching traffic) because there's no green light for the turn } \\
\text { lane...just the arrow. It'd be nice if the light gave you a go-ahead } \\
\text { without making you wait for an arrow. Thanks for letting me } \\
\text { participate, even though this isn't exactly what you were looking for! } \\
\text { David Naylor, WBAA Radio (got the info from the University News } \\
\text { Service) }\end{array}$ \\
\hline
\end{tabular}


Table B.19. Survey Results - 10A

\begin{tabular}{|c|c|c|c|c|c|c|c|c|c|c|}
\hline ID & Location & Q3 & Q3 (i) & Q4 & Q4 (j) & Q5 & Q6 & Q7 & Zip & E-mail \\
\hline 71 & $\begin{array}{c}\text { At SR } 26 \text { and } \\
\text { CR } 550 \mathrm{E}\end{array}$ & $\mathrm{f}, \mathrm{i}$ & live nearby & $\mathrm{b}, \mathrm{h}, \mathrm{j}$ & 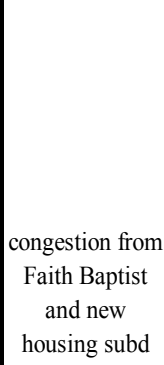 & \begin{tabular}{|c|} 
\\
\\
more \\
than \\
twice per \\
day
\end{tabular} & $\begin{array}{c}\mathrm{c}, \mathrm{f}, \mathrm{g}, \mathrm{h} \\
\end{array}$ & $\begin{array}{c}\text { less } \\
\text { than } 2 \\
\text { min }\end{array}$ & 47905 & \\
\hline 72 & $\begin{array}{c}\text { At SR } 26 \text { and } \\
\text { CR } 900 \mathrm{E}\end{array}$ & $\mathrm{c}$ & & $\mathrm{c}$ & & \begin{tabular}{|c|} 
more \\
than \\
twice per \\
day
\end{tabular} & $\mathrm{c}, \mathrm{f}, \mathrm{g}, \mathrm{h}, \mathrm{i}$ & $\begin{array}{c}\text { less } \\
\text { than } 2 \\
\text { min }\end{array}$ & 47905 & \\
\hline 73 & $\begin{array}{c}\text { At SR } 26 \text { and } \\
\text { Creasy Ln. }\end{array}$ & $\mathrm{a}, \mathrm{g}$ & & $\mathrm{g}$ & & 3-5 times & $\mathrm{c}, \mathrm{f}, \mathrm{h}$ & $\begin{array}{l}\text { less } \\
\text { than } 2 \\
\text { min }\end{array}$ & 47905 & $\begin{array}{c}\text { wayne.carter@gte } \\
\text {.net }\end{array}$ \\
\hline 74 & $\begin{array}{c}\text { At SR } 26 \text { and } \\
\text { Creasy Ln. }\end{array}$ & $\mathrm{a}, \mathrm{b}, \mathrm{f}$ & & $b, g, j$ & $\begin{array}{l}\text { Lack of } \\
\text { enforcement of } \\
\text { red lights }\end{array}$ & \begin{tabular}{|c|} 
more \\
than \\
twice per \\
day
\end{tabular} & $\begin{array}{c}\mathrm{c}, \mathrm{d}, \mathrm{e}, \mathrm{f}, \mathrm{g}, \\
\mathrm{h}\end{array}$ & $\begin{array}{l}2-4 \\
\min \end{array}$ & 47905 & \\
\hline 75 & $\begin{array}{c}\text { At SR } 26 \text { and } \\
\text { Creasy Ln. }\end{array}$ & $\mathrm{a}, \mathrm{f}$ & & $\mathrm{j}$ & $\begin{array}{c}\text { drivers } \\
\text { travelling east } \\
\text { on South Street } \\
\text { planning } \mathrm{t}\end{array}$ & $\begin{array}{l}3-5 \text { times } \\
\text { per week }\end{array}$ & $e, f, g$ & $\begin{array}{c}\text { less } \\
\text { than } 2 \\
\text { min }\end{array}$ & 47904 & $\begin{array}{c}\text { paperdcl@minds } \\
\text { pring.com }\end{array}$ \\
\hline 76 & $\begin{array}{c}\text { At SR } 26 \text { and } \\
\text { Creasy Ln. }\end{array}$ & $\mathrm{b}, \mathrm{c}, \mathrm{f}$ & & $\mathrm{c}$ & & $\begin{array}{c}\text { twice per } \\
\text { day }\end{array}$ & $\mathrm{c}, \mathrm{h}$ & $\begin{array}{l}2-4 \\
\min \end{array}$ & 47905 & $\begin{array}{c}\text { larry47905@hom } \\
\text { e.com }\end{array}$ \\
\hline 77 & $\begin{array}{c}\text { At SR } 26 \text { and } \\
\text { Creasy Ln. }\end{array}$ & $\mathrm{f}$ & & None & & p-5 times & $\mathrm{e}, \mathrm{f}, \mathrm{g}, \mathrm{h}$ & $\begin{array}{l}8-10 \\
\min \end{array}$ & 47905 & IN411LAF \\
\hline 78 & $\begin{array}{c}\text { At SR } 26 \text { and } \\
\text { Creasy Ln. }\end{array}$ & $\mathrm{a}, \mathrm{f}$ & & $g, j$ & $\begin{array}{c}\mathrm{N} \text { bound Creasy } \\
\text { light changes } \\
\text { very quickly 2-3 } \\
\text { cars }\end{array}$ & $\begin{array}{l}3-5 \text { times } \\
\text { per week }\end{array}$ & $\begin{array}{c}\text { a, d, e, g, } \\
\text { h, i }\end{array}$ & $\begin{array}{l}8-10 \\
\min \end{array}$ & 47906 & $\begin{array}{c}\text { hollyefranks@yah } \\
\text { oo.com }\end{array}$ \\
\hline
\end{tabular}


Table B.20. Survey Results - 10B

\begin{tabular}{|c|c|c|c|c|c|c|c|c|c|c|}
\hline ID & Location & M & $\mathrm{F}$ & Age & Q9 A & Q9 B & Q9 C & Q9 D & Q9 E & Comment \\
\hline 71 & $\begin{array}{l}\text { At SR } 26 \text { and } \\
\text { CR } 550 \mathrm{E}\end{array}$ & & $\mathrm{Y}$ & $36-45$ & $\mathrm{a}$ & $\mathrm{a}$ & $\mathrm{a}$ & c & $\mathrm{a}$ & $\begin{array}{l}\text { The church has grown tremendously and is now also a fast-growing } \\
\text { school. They sponsor events like the living nativity, youth groups, etc. } \\
\text { That, in addition to the huge amount of new housing (with more } \\
\text { construction planned)using } 550 \mathrm{E} \text { and } 26 \mathrm{E} \text { has resulted in tremendous } \\
\text { traffic at that intersection. People pull out onto } 26 \text { from } 550 \text { right in } \\
\text { front of oncoming traffic. As a driver dealing with that, as well as } \\
\text { trying to get out of Heritage Estates onto } 26 \text {, turning left onto } 26 \text { to } \\
\text { take my kids to Rossville school, it is a royal PAIN. Especially in } \\
\text { winter, because you can't get enough traction to get out onto the } \\
\text { highway quickly (need salt on Mahan drive, please). (Same deal at the } \\
\text { entrance to Pineview Subdivision--we commute with a family there. } \\
\text { You can't see oncoming traffic from the east due to curve in road. You } \\
\text { are stopped on Pineview with a slight uphill slant, bad visibility from } \\
\text { east, and no salt to help you get traction. School buses also have to } \\
\text { deal with this. You literally take your life in your hands trying to turn } \\
\text { toward Rossville there.) Many times, the people coming off of } 550 \text { by }\end{array}$ \\
\hline 72 & $\begin{array}{l}\text { At SR } 26 \text { and } \\
\text { CR } 900 \mathrm{E}\end{array}$ & & $\mathrm{Y}$ & $36-45$ & $\mathrm{a}$ & $\mathrm{a}$ & $\mathrm{a}$ & $\mathrm{a}$ & $\mathrm{a}$ & $\begin{array}{l}\text { Needs a bypass lane for eastbound cars to go around those turning } \\
\text { north onto } 900 \mathrm{E} \text { from } 26 \text {. }\end{array}$ \\
\hline 73 & $\begin{array}{c}\text { At SR } 26 \text { and } \\
\text { Creasy Ln. }\end{array}$ & & $\mathrm{Y}$ & $36-45$ & $\mathrm{a}$ & $\mathrm{a}$ & $\mathrm{a}$ & $\mathrm{a}$ & $\mathrm{a}$ & $\begin{array}{l}\text { In the evening if you are on Creasy going North across } 26 \text { East the } \\
\text { light only stays green for } 2 \text { to } 3 \text { cars to get through the light. There is } \\
\text { usually more than that in line, and the wait for that light is long so } \\
\text { people get disgusted and just go through on red. I've caught myself } \\
\text { doing it before. It is totally crazy. Creasy is a busy road even in the } \\
\text { evening. It needs to be set up so more cars can get through. P.S. I've } \\
\text { only noticed this in the evening hours, in the day it seems to be ok. }\end{array}$ \\
\hline 74 & $\begin{array}{l}\text { At SR } 26 \text { and } \\
\text { Creasy Ln. }\end{array}$ & $\mathrm{Y}$ & & $36-45$ & $\mathrm{a}$ & a & $\mathrm{a}$ & c & c & \\
\hline 75 & $\begin{array}{l}\text { At SR } 26 \text { and } \\
\text { Creasy Ln. }\end{array}$ & & $\mathrm{Y}$ & $65+$ & $\mathrm{a}$ & $\mathrm{a}$ & $\mathrm{a}$ & $\mathrm{a}$ & a & $\begin{array}{l}\text { Congestion at this intersection and potential for collisions might be } \\
\text { relieved by making the above right turn lane off South Street onto } \\
\text { Creasy Lane longer than it is. }\end{array}$ \\
\hline 76 & $\begin{array}{l}\text { At SR } 26 \text { and } \\
\text { Creasy Ln. }\end{array}$ & $\mathrm{Y}$ & & $56-65$ & a & $\mathrm{a}$ & a & c & $\mathrm{b}$ & $\begin{array}{l}\text { The turn lanes should be two lanes on } 26 \text { to Creasy lane South and two } \\
\text { lanes on Creasy Lane South to } 26 \text { East }\end{array}$ \\
\hline 77 & $\begin{array}{c}\text { At SR } 26 \text { and } \\
\text { Creasy Ln. }\end{array}$ & & $\mathrm{Y}$ & $56-65$ & $\mathrm{a}$ & a & $\mathrm{a}$ & $\mathrm{b}$ & $\mathrm{b}$ & $\begin{array}{l}\text { Why can't a road be made to the restaurants on } 26 \text { by way of a new } \\
\text { road behind Orchard Heights. There seems to be enough room and } \\
\text { would eliminate lots of traffic at the intersection. Also this road could } \\
\text { come out at some place to intersect with } 26 \text { at another point further } \\
\text { east. }\end{array}$ \\
\hline 78 & $\begin{array}{l}\text { At SR } 26 \text { and } \\
\text { Creasy Ln. }\end{array}$ & & $\mathrm{Y}$ & $16-25$ & c & $\mathrm{a}$ & $\mathrm{a}$ & $\mathrm{b}$ & $\mathrm{a}$ & $\begin{array}{l}\text { The labels on the map are difficult to read. Perhaps having at the } \\
\text { beginning a boz to type in the intersection if someone knows it. }\end{array}$ \\
\hline
\end{tabular}


Table B.21. Survey Results $-11 \mathrm{~A}$

\begin{tabular}{|c|c|c|c|c|c|c|c|c|c|c|}
\hline ID & Location & Q3 & Q3 (i) & Q4 & Q4 (j) & Q5 & Q6 & Q7 & Zip & E-mail \\
\hline 79 & $\begin{array}{c}\text { At SR } 26 \text { and } \\
\text { Earl Ave. }\end{array}$ & $\mathrm{f}$ & & None & & $\begin{array}{c}\text { more } \\
\text { than } \\
\text { twice per } \\
\text { day }\end{array}$ & $\mathrm{d}, \mathrm{e}, \mathrm{h}$ & $\begin{array}{c}\text { less } \\
\text { than } 2 \\
\text { min }\end{array}$ & 47905 & \\
\hline 80 & $\begin{array}{l}\text { At SR } 26 \text { and } \\
\text { Frontage Rd. }\end{array}$ & $\mathrm{f}, \mathrm{i}$ & $\mid \begin{array}{c}\text { turning left to east } \\
\text { bound lane is very } \\
\text { difficult }\end{array}$ & $\mathrm{h}$ & & $\mid \begin{array}{l}1-3 \text { times } \\
\text { per week }\end{array}$ & $\mathrm{c}, \mathrm{g}$ & None & 47905 & $\begin{array}{c}\text { ThmBarr@aol.co } \\
\mathrm{m}\end{array}$ \\
\hline 81 & $\begin{array}{l}\text { At SR } 26 \text { and } \\
\text { Frontage Rd. }\end{array}$ & $\mathrm{f}$ & & $\mathrm{h}$ & & $\begin{array}{c}\text { twice per } \\
\text { day }\end{array}$ & $\mathrm{c}, \mathrm{h}$ & $\begin{array}{c}\text { less } \\
\text { than } 2 \\
\text { min }\end{array}$ & 47905 & $\begin{array}{c}\text { larry47905@hom } \\
\text { e.com }\end{array}$ \\
\hline 82 & $\begin{array}{c}\text { At SR } 26 \text { and } \\
\text { Klondike }\end{array}$ & $\mathrm{i}$ & $\begin{array}{c}\text { personal } \\
\text { observation }\end{array}$ & $\mathrm{a}, \mathrm{b}$ & & $\begin{array}{c}\text { twice per } \\
\text { day }\end{array}$ & $\mathrm{c}, \mathrm{g}$ & $\begin{array}{c}\text { less } \\
\text { than } 2 \\
\text { min }\end{array}$ & 47906 & $\begin{array}{c}\text { jmccammack@p } \\
\text { mc.purdue.edu }\end{array}$ \\
\hline 83 & $\begin{array}{l}\text { At SR } 26 \text { and } \\
\text { Pineview Ln. }\end{array}$ & $\mathrm{f}$ & & $\mathrm{a}, \mathrm{b}, \mathrm{i}$ & & \begin{tabular}{|c|} 
more \\
than \\
twice per \\
day
\end{tabular} & $\mathrm{c}, \mathrm{f}, \mathrm{g}, \mathrm{h}, \mathrm{i}$ & $\begin{array}{c}\text { less } \\
\text { than } 2 \\
\text { min }\end{array}$ & 47905 & \\
\hline 84 & $\begin{array}{c}\text { At SR } 28 \text { and } \\
\text { CR } 975 \mathrm{E}\end{array}$ & $\mathrm{e}, \mathrm{f}, \mathrm{g}$ & & $a, b, e, i, j$ & $\begin{array}{l}\text { Speed limit on } \\
\text { Hwy28 to high }\end{array}$ & $\begin{array}{c}\text { twice per } \\
\text { day }\end{array}$ & $\mathrm{c}, \mathrm{h}$ & $\begin{array}{l}4-6 \\
\min \end{array}$ & 47930 & $\begin{array}{c}\text { Lmrk481@cs.co } \\
\text { m }\end{array}$ \\
\hline 85 & $\begin{array}{l}\text { At SR } 43 \text { and } \\
\text { Bennett Rd. }\end{array}$ & $a, f$ & & $b, j$ & $\begin{array}{c}\text { There is a stop } \\
\text { sign, but no } \\
\text { stoplight }\end{array}$ & \begin{tabular}{|c} 
more \\
than \\
twice per \\
day
\end{tabular} & $\begin{array}{c}\mathrm{c}, \mathrm{d}, \mathrm{e}, \mathrm{f}, \mathrm{g}, \\
\mathrm{h}\end{array}$ & $\begin{array}{l}2-4 \\
\min \end{array}$ & 47906 & $\begin{array}{c}\text { Morgan_Rebecca } \\
\text { @ } \mathrm{msn} . c 0 \mathrm{~m}\end{array}$ \\
\hline
\end{tabular}


Table B.22. Survey Results - 11B

\begin{tabular}{|c|c|c|c|c|c|c|c|c|c|c|}
\hline ID & Location & M & $\mathrm{F}$ & Age & Q9 A & Q9 B & Q9 C & Q9 D & Q9 E & Comment \\
\hline 79 & $\begin{array}{c}\text { At SR } 26 \text { and } \\
\text { Earl Ave. }\end{array}$ & $\mathrm{Y}$ & & $|26-35|$ & $\mathrm{a}$ & $\mathrm{a}$ & $\mathrm{a}$ & $\mathrm{a}$ & $\mathrm{a}$ & $\begin{array}{l}\text { It is difficult to turn east from Earl Avenue on to Indiana 26/South St. } \\
\text { because of vehicles backed up that are waiting to get through the } \\
\text { intersection of U.S. } 52 \text { and Indiana } 26 .\end{array}$ \\
\hline 80 & $\begin{array}{l}\text { At SR } 26 \text { and } \\
\text { Frontage Rd. }\end{array}$ & $\mathrm{Y}$ & & $26-35 \mid$ & $\mathrm{a}$ & $\mathrm{a}$ & $\mathrm{a}$ & $\mathrm{a}$ & $\mathrm{a}$ & \\
\hline 81 & $\begin{array}{l}\text { At SR } 26 \text { and } \\
\text { Frontage Rd. }\end{array}$ & $\mathrm{Y}$ & & $56-65$ & $\mathrm{a}$ & $\mathrm{a}$ & $\mathrm{a}$ & c & $\mathrm{b}$ & $\begin{array}{l}\text { Highway } 26 \text { East needs a planted median from } 65 \text { to } 52 \text { with two turn } \\
\text { lanes on Creasy lane and off Creasylane. We also need an exit off } 65 \text { to } \\
\text { Union street and off to McCarty Lane The Purdue traffic off } 65 \text { back up } \\
\text { on } 65 \text { for } 26 \text {. Highway } 65 \text { needs six lanes through Lafayette with sound } \\
\text { barriers. We need trees planted alone the highways. Less snow drift } \\
\text { will occur. }\end{array}$ \\
\hline 82 & $\begin{array}{c}\text { At SR } 26 \text { and } \\
\text { Klondike }\end{array}$ & $\mathrm{Y}$ & & $46-55 \mid$ & $\mathrm{a}$ & $\mathrm{a}$ & $\mathrm{a}$ & $\mathrm{a}$ & $\mathrm{a}$ & $\begin{array}{l}\text { I turn east to travel to Purdue daily. Intersection is such that it's } \\
\text { necessary to pull far forward to see eastbount traffic (usually travelling } \\
\text { too fast on SR26) and making it difficult for eastbound traffic on } 26 \text { to } \\
\text { left turn onto Klondike. The hill to the west obstructs vision. Rain or } \\
\text { snow makes it more hazardous than usual. }\end{array}$ \\
\hline 83 & $\begin{array}{l}\text { At SR } 26 \text { and } \\
\text { Pineview Ln. }\end{array}$ & & $\mathrm{Y}$ & $|36-45|$ & $\mathrm{a}$ & $\mathrm{a}$ & $\mathrm{a}$ & $\mathrm{a}$ & $\mathrm{a}$ & $\begin{array}{l}\text { Can't see oncoming traffic from East as you wait to exit Pineview } \\
\text { subdivision. Uphill slant on Pineview exit combined with not enough } \\
\text { plowing/salt in snow results in no traction to get out in front of } \\
\text { careening cars from east. }\end{array}$ \\
\hline 84 & $\begin{array}{c}\text { At SR } 28 \text { and } \\
\text { CR } 975 \text { E }\end{array}$ & Y & & $|36-45|$ & $\mathrm{a}$ & $\mathrm{a}$ & $\mathrm{a}$ & b & b & $\begin{array}{l}\text { This intersection has many bad points and is the main way in and out } \\
\text { of the town of Clarks Hill. Just dropping the speed from } 55 \text { to } 45 \text { on } \\
\text { Hwy } 28 \text { and putting dangerous intersection signs up on } 28 \text { would help } \\
\text { greatly. Right now there is nothing marking the intersection except for } \\
\text { the town signs on } 28 \text {. You stop on } 975 \text { you can see to the east fairly } \\
\text { well but looking to the west there is a dip in the road,sun in your eyes } \\
\text { in the evening and in the summer corn field and winter piled up snow. }\end{array}$ \\
\hline 85 & $\begin{array}{c}\text { At SR } 43 \text { and } \\
\text { Bennett Rd. }\end{array}$ & & $\mathrm{Y}$ & $|36-45|$ & $\mathrm{a}$ & $\mathrm{a}$ & $\mathrm{a}$ & $\mathrm{a}$ & $\mathrm{a}$ & $\begin{array}{l}\text { The intersection of Highway } 43 \text { and Burnett Road is very dangerous. } \\
\text { There is often both heavy traffic and high speeds, making a left turn } \\
\text { from Burnett Road onto Highway } 43 \text { very difficult and risky. I feel that } \\
\text { a stoplight at this intersection would improve the situation greatly and } \\
\text { avert an accident that, unfortunately, I believe is bound to happen. } \\
\text { This intersection was changed and improved not too long ago by } \\
\text { altering the intersection of Prophet's Rock Road and Burnett Road. } \\
\text { However, although this did improve things, the situation is still quite } \\
\text { dangerous. I appreciate the existence of this site to voice my concerns. } \\
\text { Thanks. }\end{array}$ \\
\hline
\end{tabular}


Table B.23. Survey Results $-12 \mathrm{~A}$

\begin{tabular}{|c|c|c|c|c|c|c|c|c|c|c|}
\hline ID & Location & Q3 & Q3 (i) & Q4 & Q4 (j) & Q5 & Q6 & Q7 & Zip & E-mail \\
\hline 86 & $\begin{array}{c}\text { At SR } 43 \text { and } \\
\text { Bennett Rd. }\end{array}$ & $\mathrm{a}, \mathrm{b}, \mathrm{f}$ & & $\mathrm{a}$ & & $\begin{array}{l}3-5 \text { times } \\
\text { per week }\end{array}$ & $\mathrm{c}, \mathrm{d}, \mathrm{f}, \mathrm{g}, \mathrm{h}$ & $\begin{array}{l}4-6 \\
\min \end{array}$ & 47906 & $\begin{array}{c}\text { gm543@home.co } \\
\text { m }\end{array}$ \\
\hline 87 & $\begin{array}{c}\text { At SR } 43 \text { and } \\
\text { CR } 600 \mathrm{~N}\end{array}$ & $\mathrm{f}$ & & $b, j$ & Limited lanes & None & $\mathrm{c}, \mathrm{g}$ & $\begin{array}{l}2-4 \\
\min \end{array}$ & 47906 & $\begin{array}{c}\text { tl.phillips@home. } \\
\text { com }\end{array}$ \\
\hline 88 & $\begin{array}{c}\text { At SR } 43 \text { and } \\
\text { I- } 65\end{array}$ & $a, f$ & & $\mathrm{j}$ & $\begin{array}{c}\text { Too many lanes } \\
\text { to cross w/o } \\
\text { signal. }\end{array}$ & $\begin{array}{l}3-5 \text { times } \\
\text { per week }\end{array}$ & $c, e, f, g$ & $\begin{array}{l}8-10 \\
\min \end{array}$ & 47906 & \\
\hline 89 & $\begin{array}{l}\text { At Stadium } \\
\text { Ave. and } \\
\text { Robinson St. }\end{array}$ & d & & $\mathrm{a}$ & & $\begin{array}{c}\text { once per } \\
\text { day }\end{array}$ & $\mathrm{f}$ & $\begin{array}{l}6-8 \\
\min \end{array}$ & 47906 & \\
\hline 90 & $\begin{array}{l}\text { At Stadium } \\
\text { Ave. and } \\
\text { Robinson St. }\end{array}$ & $\mathrm{b}, \mathrm{d}, \mathrm{g}$ & & $\mathrm{a}, \mathrm{b}$ & & $\begin{array}{l}3-5 \text { times } \\
\text { per week }\end{array}$ & $\mathrm{e}$ & $\begin{array}{l}8-10 \\
\min \end{array}$ & 47906 & \\
\hline 91 & $\begin{array}{c}\text { At State St. } \\
\text { and Russell } \\
\text { St. }\end{array}$ & $a, b, f, g$ & & $f, j$ & $\begin{array}{c}\text { Not enough of } \\
\text { the right lane } \\
\text { markings }\end{array}$ & $\begin{array}{c}\text { twice per } \\
\text { day }\end{array}$ & $\mathrm{d}, \mathrm{f}$ & $\begin{array}{l}4-6 \\
\min \end{array}$ & 47993 & $\begin{array}{c}\text { dwhite@purdue.e } \\
\text { du }\end{array}$ \\
\hline 92 & $\begin{array}{c}\text { At State St. } \\
\text { and University } \\
\text { St. }\end{array}$ & $\mathrm{a}, \mathrm{c}, \mathrm{f}, \mathrm{i}$ & $\begin{array}{c}\text { witnessed several } \\
\text { accidents, } \\
\text { including injury }\end{array}$ & $\mathrm{b}, \mathrm{c}, \mathrm{f}, \mathrm{g}$ & & \begin{tabular}{|c|} 
more \\
than \\
twice per \\
day
\end{tabular} & $\mathrm{e}, \mathrm{g}$ & $\begin{array}{l}6-8 \\
\min \end{array}$ & 47906 & $\begin{array}{c}\text { pschwab@purdue } \\
\text {.edu }\end{array}$ \\
\hline 93 & $\begin{array}{c}\text { At Teal Rd. } \\
\text { and Bennett } \\
\text { Rd. }\end{array}$ & $\mathrm{a}, \mathrm{b}, \mathrm{c}, \mathrm{f}$ & & $\mathrm{b}, \mathrm{c}, \mathrm{h}$ & & $\begin{array}{c}\text { twice per } \\
\text { day }\end{array}$ & $\begin{array}{c}\mathrm{c}, \mathrm{d}, \mathrm{e}, \mathrm{f}, \mathrm{g}, \\
\mathrm{h}, \mathrm{i}\end{array}$ & $\begin{array}{c}\text { less } \\
\text { than } 2 \\
\text { min }\end{array}$ & 47909 & \\
\hline 94 & $\begin{array}{c}\text { At Teal Rd. } \\
\text { and Concord } \\
\text { Rd. }\end{array}$ & $\mathrm{a}$ & & $\mathrm{j}$ & $\begin{array}{c}\text { vehicles turning } \\
\text { left }\end{array}$ & per week & $\mathrm{h}$ & $\begin{array}{l}2-4 \\
\min \end{array}$ & 47909 & \\
\hline 95 & $\begin{array}{c}\text { At Teal Rd. } \\
\text { and Concord } \\
\text { Rd. }\end{array}$ & $\mathrm{g}$ & & $\mathrm{j}$ & $\begin{array}{c}\text { Westbound Left } \\
\text { Turns }\end{array}$ & $\begin{array}{l}1-3 \text { times } \\
\text { per week }\end{array}$ & $\mathrm{d}, \mathrm{h}$ & $\begin{array}{l}\text { less } \\
\text { than } 2 \\
\text { min }\end{array}$ & 47933 & \\
\hline
\end{tabular}


Table B.24. Survey Results - 12B

\begin{tabular}{|c|c|c|c|c|c|c|c|c|c|c|}
\hline ID & Location & M & $\mathrm{F}$ & Age & Q9 A & Q9 B & Q9 C & Q9 D & Q9 E & Comment \\
\hline 86 & $\begin{array}{l}\text { At SR } 43 \text { and } \\
\text { Bennett Rd. }\end{array}$ & $\mathrm{Y}$ & & $56-65$ & a & $\mathrm{a}$ & a & $\mathrm{a}$ & a & $\begin{array}{l}\text { The problem is for South bound traffic turning left onto Burnett road. } \\
\text { There are no lane markers indicating where the turning traffic should } \\
\text { be. The incline of } 43 \text { makes it impossible to see across the road as to } \\
\text { where exactly you should be turning. The problem is not too bad in } \\
\text { daylight but at night it is totally impossible. Drivers unfamiliar with } \\
\text { the intersection have no idea where to turn until they are committed } \\
\text { and in the middle of } 43 \text {. Some turn lanes painted on the road would } \\
\text { correct this problem. }\end{array}$ \\
\hline 87 & $\begin{array}{l}\text { At SR } 43 \text { and } \\
\text { CR } 600 \mathrm{~N}\end{array}$ & $\mathrm{Y}$ & & $56-65$ & $\mathrm{a}$ & $\mathrm{a}$ & a & $\mathrm{a}$ & $\mathrm{a}$ & $\begin{array}{l}\text { Many drivers use shoulders as highspeed passing lanes when other } \\
\text { drivers are turning. }\end{array}$ \\
\hline 88 & $\begin{array}{l}\text { At SR } 43 \text { and } \\
\text { I-65 }\end{array}$ & $\mathrm{Y}$ & & $46-55$ & $\mathrm{a}$ & a & $\mathrm{a}$ & $\mathrm{a}$ & a & \\
\hline 89 & $\begin{array}{c}\text { At Stadium } \\
\text { Ave. and } \\
\text { Robinson St. }\end{array}$ & & $\mathrm{Y}$ & $65+$ & $\mathrm{a}$ & a & $\mathrm{a}$ & a & $\mathrm{b}$ & $\begin{array}{l}\text { Not only have I been in an accident (in a car driven by someone other } \\
\text { than myself) at this intersection, I have also had a near-miss when I } \\
\text { myself was driving. The angle of the intersection and the presence of a } \\
\text { large Sycamore tree, plus possibly parked cars, on Robinson, make it a } \\
\text { bad intersection. The difficulty occurs for drivers going east on } \\
\text { Stadium. }\end{array}$ \\
\hline 90 & $\begin{array}{c}\text { At Stadium } \\
\text { Ave. and } \\
\text { Robinson St. }\end{array}$ & $\mathrm{Y}$ & & $56-65$ & $\mathrm{a}$ & $\mathrm{a}$ & a & b & b & $\begin{array}{l}\text { The angle of Robinson Street makes it difficult to see approaching } \\
\text { traffic when one is on Stadium headed east. Parked cars on Robinson } \\
\text { to the south add to the problem. Also, a big tree on Robinson north of } \\
\text { Stadium obscures vision. Traffic on Robinson often moves very } \\
\text { quickly, making crossing risky if visibility is poor. }\end{array}$ \\
\hline 91 & $\begin{array}{c}\text { At State St. } \\
\text { and Russell } \\
\text { St. }\end{array}$ & $\mathrm{Y}$ & & $46-55$ & a & $\mathrm{a}$ & a & $\mathrm{a}$ & a & $\begin{array}{l}\text { State street was reblacktopped this fall. When the painted lane } \\
\text { markings on State street, they did not show that East bound State street } \\
\text { drifts south as it crosses Russell street. Drivers in the south } \\
\text { lane,(headed east) drive directly in front of the north lane, because the } \\
\text { don't relize that the lanes shift to the south. I have nearly been hit } \\
\text { several times since this was repainted this fall. }\end{array}$ \\
\hline 92 & $\begin{array}{c}\text { At State St. } \\
\text { and University } \\
\text { St. }\end{array}$ & $\mathrm{Y}$ & & $46-55$ & $\mathrm{a}$ & a & a & $\mathrm{a}$ & $\mathrm{a}$ & $\begin{array}{l}\text { High volumes of pedestrian and vehicle traffic make this intersection } \\
\text { (and State street near this intersection) dangerous. The lights are } \\
\text { sequenced properly, but the students and faculty seem determined to } \\
\text { kill themselves. }\end{array}$ \\
\hline 93 & $\begin{array}{l}\text { At Teal Rd. } \\
\text { and Bennett } \\
\text { Rd. }\end{array}$ & & $\mathrm{Y}$ & $36-45$ & $\mathrm{a}$ & $\mathrm{a}$ & $\mathrm{a}$ & b & $\mathrm{b}$ & $\begin{array}{l}\text { I think the location is dangerous because vehicles traveling west on } \\
\text { Teal Road are often traveling too fast to stop for vehicles turning left on } \\
\text { Bennett Road. "Watch for Left Turn" signs might improve the } \\
\text { situation. By the way, I think this type of survey would be great for } \\
\text { city and county government web sites. }\end{array}$ \\
\hline 94 & $\begin{array}{c}\text { At Teal Rd. } \\
\text { and Concord } \\
\text { Rd. }\end{array}$ & $\mathrm{Y}$ & & $36-45$ & $\mathrm{a}$ & $\mathrm{a}$ & a & $\mathrm{a}$ & $\mathrm{c}$ & There is not link to see a summary of responses. \\
\hline 95 & $\begin{array}{l}\text { At Teal Rd. } \\
\text { and Concord } \\
\text { Rd. }\end{array}$ & $\mathrm{Y}$ & & $46-55$ & a & a & a & a & $\mathrm{a}$ & \\
\hline
\end{tabular}


Table B.25. Survey Results $-13 \mathrm{~A}$

\begin{tabular}{|c|c|c|c|c|c|c|c|c|c|c|}
\hline ID & Location & Q3 & Q3 (i) & Q4 & Q4 (j) & Q5 & Q6 & Q7 & Zip & E-mail \\
\hline 96 & $\begin{array}{c}\text { At Teal Rd. } \\
\text { and Concord } \\
\text { Rd. }\end{array}$ & $\mathrm{b}, \mathrm{g}$ & & $\mathrm{f}$ & & $\begin{array}{l}1-3 \text { times } \\
\text { per week }\end{array}$ & $\mathrm{a}, \mathrm{d}, \mathrm{f}$ & $\begin{array}{c}\text { less } \\
\text { than } 2 \\
\text { min }\end{array}$ & 47905 & \\
\hline 97 & $\begin{array}{c}\text { At Teal Rd. } \\
\text { and Concord } \\
\text { Rd. }\end{array}$ & $\mathrm{b}, \mathrm{c}, \mathrm{f}$ & & $c, j$ & $\begin{array}{c}\text { no left turns are } \\
\text { supposed to be } \\
\text { made off } \\
\text { Concord }\end{array}$ & $\begin{array}{c}\text { more } \\
\text { than } \\
\text { twice per } \\
\text { day }\end{array}$ & $\mathrm{c}, \mathrm{f}, \mathrm{g}$ & $\begin{array}{c}\text { less } \\
\text { than } 2 \\
\text { min }\end{array}$ & 47909 & \\
\hline 98 & $\begin{array}{c}\text { At Teal Rd. } \\
\text { and Concord } \\
\text { Rd. }\end{array}$ & d & & $\mathrm{a}, \mathrm{b}, \mathrm{h}$ & & $\begin{array}{l}3-5 \text { times } \\
\text { per week }\end{array}$ & $\mathrm{d}, \mathrm{e}, \mathrm{f}, \mathrm{h}$ & $\begin{array}{l}2-4 \\
\min \end{array}$ & 47975 & \\
\hline 99 & $\begin{array}{c}\text { At Teal Rd. } \\
\text { and Earl Ave. } \\
\text { (22nd St.) }\end{array}$ & $\mathrm{a}, \mathrm{f}, \mathrm{h}, \mathrm{i}$ & $\begin{array}{l}\text { run red light } \\
\text { constantly }\end{array}$ & $\mathrm{b}$ & & $\begin{array}{c}\text { twice per } \\
\text { day }\end{array}$ & $\mathrm{b}, \mathrm{h}$ & $\begin{array}{c}\text { less } \\
\text { than } 2 \\
\text { min }\end{array}$ & 47909 & \\
\hline 100 & \begin{tabular}{|c|} 
At Teal Rd. \\
and Earl Ave. \\
(22nd St.)
\end{tabular} & $\mathrm{c}, \mathrm{f}$ & $\begin{array}{l}\text { I am a crossing } \\
\text { guard during the } \\
\text { school year at th }\end{array}$ & $\mathrm{b}, \mathrm{c}, \mathrm{f}$ & & $\begin{array}{l}3-5 \text { times } \\
\text { per week }\end{array}$ & $\begin{array}{c}\mathrm{c}, \mathrm{d}, \mathrm{e}, \mathrm{f}, \mathrm{g}, \\
\mathrm{h}\end{array}$ & $\begin{array}{c}\text { less } \\
\text { than } 2 \\
\text { min }\end{array}$ & 47909 & $\begin{array}{c}\text { StrongerNewMe } \\
\text { @aol.com }\end{array}$ \\
\hline 101 & $\begin{array}{l}\text { At Teal Rd. } \\
\text { and } \\
\text { Summerfield } \\
\text { Dr. }\end{array}$ & $\mathrm{c}, \mathrm{f}$ & $\begin{array}{c}\mathrm{I} \text { am a crossing } \\
\text { guard during the } \\
\text { school year and } \mathrm{T}\end{array}$ & $\mathrm{b}, \mathrm{c}, \mathrm{f}, \mathrm{h}$ & & $\begin{array}{c}\text { more } \\
\text { than } \\
\text { twice per } \\
\text { day }\end{array}$ & $\frac{c, d, e, f, g}{h}$ & $\begin{array}{l}2-4 \\
\min \end{array}$ & 47909 & $\begin{array}{c}\text { StrongerNewMe } \\
\text { @aol.com }\end{array}$ \\
\hline 102 & $\begin{array}{c}\text { At } \\
\text { Underwood } \\
\text { St. and 20th } \\
\text { St. }\end{array}$ & $\mathrm{f}$ & $\begin{array}{c}\text { I live there \& see } \\
\text { it all the time }\end{array}$ & $\mathrm{j}$ & $\begin{array}{l}\text { Disregard for } \\
\text { stop signs! }\end{array}$ & $\begin{array}{c}\text { more } \\
\text { than } \\
\text { twice per } \\
\text { day }\end{array}$ & $\mathrm{b}, \mathrm{g}$ & None & 47904 & $\begin{array}{c}\text { jelburn@purdue.e } \\
\mathrm{du}\end{array}$ \\
\hline 103 & $\begin{array}{c}\text { At US } 231 \\
\text { and CR } 350 \mathrm{~S}\end{array}$ & $\mathrm{i}$ & observation & $\mathrm{j}$ & $\begin{array}{c}\text { missing hazard } \\
\text { sign on car } \\
\text { opener }\end{array}$ & $\begin{array}{l}1-3 \text { times } \\
\text { per week }\end{array}$ & $\mathrm{g}$ & $\begin{array}{c}\text { less } \\
\text { than } 2 \\
\text { min }\end{array}$ & 47909 & $\begin{array}{c}\text { dave@americanp } \\
\text { cnic.com }\end{array}$ \\
\hline
\end{tabular}


Table B.26. Survey Results - 13B

\begin{tabular}{|c|c|c|c|c|c|c|c|c|c|c|}
\hline ID & Location & $\mathrm{M}$ & $\mathrm{F}$ & Age & Q9 A & Q9 B & Q9 C & Q9 D & Q9 E & Comment \\
\hline 96 & $\begin{array}{c}\text { At Teal Rd. } \\
\text { and Concord } \\
\text { Rd. }\end{array}$ & $\mathrm{Y}$ & & $\mid 26-35$ & $\mathrm{a}$ & $\mathrm{a}$ & $\mathrm{a}$ & $\mathrm{a}$ & $\mathrm{a}$ & \\
\hline 97 & $\begin{array}{c}\text { At Teal Rd. } \\
\text { and Concord } \\
\text { Rd. }\end{array}$ & Y & & $56-65$ & $\mathrm{a}$ & $\mathrm{a}$ & $\mathrm{a}$ & b & b & $\begin{array}{l}\text { I don't feel the answers available in the drop down boxes cover } \\
\text { comments people like me may have }\end{array}$ \\
\hline 98 & $\begin{array}{c}\text { At Teal Rd. } \\
\text { and Concord } \\
\text { Rd. }\end{array}$ & & Y & $36-45$ & $\mathrm{a}$ & $\mathrm{a}$ & $\mathrm{a}$ & $\mathrm{b}$ & $\mathrm{a}$ & $\begin{array}{l}\text { People should not be allowed to turn left from Teal onto Concord. } \\
\text { They are trying to cross } 2 \text { lanes of traffic and many are already in that } \\
\text { lane to get in the turn lane to the mall. Those heading to the mall and } \\
\text { those turning can't see the others. I know, I was involved in an } \\
\text { accident there. Also, it holds up traffic. }\end{array}$ \\
\hline 99 & $\begin{array}{c}\text { At Teal Rd. } \\
\text { and Earl Ave. } \\
\text { (22nd St.) }\end{array}$ & & $\mathrm{Y}$ & $46-55$ & $\mathrm{a}$ & $\mathrm{a}$ & $\mathrm{a}$ & $\mathrm{a}$ & $\mathrm{a}$ & $\begin{array}{l}\text { I find that this location is very bad for running the red light, especially } \\
\text { East bound traffic for some reason. Turning off of Summerfield Drive } \\
\text { onto Teal Rd. is very dangerous because of the running of the red light. } \\
\text { I have had some near misses from red light runners. }\end{array}$ \\
\hline 100 & $\begin{array}{c}\text { At Teal Rd. } \\
\text { and Earl Ave. } \\
\text { (22nd St.) }\end{array}$ & & $\mathrm{Y}$ & $|36-45|$ & $\mathrm{a}$ & $\mathrm{a}$ & $\mathrm{a}$ & $\mathrm{a}$ & $\mathrm{c}$ & $\begin{array}{l}\text { Bypassing this intersection is not really an option for many people. } \\
\text { The problem is that people just want to try to beat the light. The other } \\
\text { thing is that the people driving cars do not understand that pedestrians } \\
\text { have the right of way. Even when someone has the "Walk" signal, cars } \\
\text { will try to cross in front of or around people walking in the crosswalks. } \\
\text { This is a VERY dangerous intersection. }\end{array}$ \\
\hline 101 & $\begin{array}{l}\text { At Teal Rd. } \\
\text { and } \\
\text { Summerfield } \\
\text { Dr. }\end{array}$ & & Y & $36-45$ & $\mathrm{a}$ & $\mathrm{a}$ & $\mathrm{a}$ & $\mathrm{a}$ & $\mathrm{c}$ & $\begin{array}{l}\text { There is a stop sign at this corner for the drivers on Summerfield, } \\
\text { however, people drive very fast down Teal Road, and drivers trying to } \\
\text { turn onto Teal going either west or east are often "aking their lives into } \\
\text { their own hands" so to speak. There are numerous accidents at this } \\
\text { intersection. }\end{array}$ \\
\hline 102 & $\begin{array}{l}\text { At } \\
\text { Underwood } \\
\text { St. and } 20 \text { th } \\
\text { St. }\end{array}$ & Y & & $46-55$ & $\mathrm{a}$ & $\mathrm{a}$ & $\mathrm{a}$ & $\mathrm{a}$ & $\mathrm{a}$ & I didn't answer \#7 because I live at the area in question. \\
\hline 103 & $\begin{array}{c}\text { At US } 231 \\
\text { and CR } 350 \mathrm{~S}\end{array}$ & Y & & $36-45$ & $\mathrm{a}$ & a & $\mathrm{a}$ & $\mathrm{b}$ & $\mathrm{b}$ & $\begin{array}{l}\text { The center wall dividing nortbound and southbound lanes of } 231 \text { is } \\
\text { missing the diagonally striped, yellow and black vertical sign which } \\
\text { indicates the blunt, open end of the center wall. This is as traveling } \\
\text { southbound on SR } 231 \text {, turning left onto Lafayette's } 350 \text { South. Also, I } \\
\text { think there will be a lot of cars sliding into this in the winter time if } \\
\text { extra salt isn't used. Since so many people will be hitting this (it } \\
\text { already is pretty banged up from hits) it may be better to paint the } \\
\text { strips on with reflective paint instead of using another (expensive!) } \\
\text { metal sign. } \\
\text { Thanks, Dave }\end{array}$ \\
\hline
\end{tabular}


Table B.27. Survey Results $-14 \mathrm{~A}$

\begin{tabular}{|c|c|c|c|c|c|c|c|c|c|c|}
\hline ID & Location & Q3 & Q3 (i) & Q4 & Q4 (j) & Q5 & Q6 & Q7 & Zip & E-mail \\
\hline 104 & $\begin{array}{c}\text { At US } 52 \text { and } \\
\text { Brady Ln. }\end{array}$ & $\mathrm{a}, \mathrm{f}$ & & $\mathrm{b}$ & & $\begin{array}{c}\text { more } \\
\text { than } \\
\text { twice per } \\
\text { day }\end{array}$ & $\mathrm{e}, \mathrm{g}, \mathrm{h}$ & $\begin{array}{l}8-10 \\
\min \end{array}$ & 47909 & $\begin{array}{c}\text { tegdirb27@hotma } \\
\text { il.com }\end{array}$ \\
\hline 105 & $\begin{array}{c}\text { At US } 52 \text { and } \\
\text { CR } 350 \mathrm{~S}\end{array}$ & $a, f$ & & $\mathrm{~b}, \mathrm{~g}, \mathrm{j}$ & $\begin{array}{c}\text { light changes to } \\
\text { quickly }\end{array}$ & $\begin{array}{l}1-3 \text { times } \\
\text { per week }\end{array}$ & $\mathrm{d}, \mathrm{g}$ & $\begin{array}{l}2-4 \\
\min \end{array}$ & 47918 & \\
\hline 106 & $\begin{array}{l}\text { At US } 52 \text { and } \\
\text { CR } 400 \mathrm{~W}\end{array}$ & $\mathrm{a}, \mathrm{f}, \mathrm{i}$ & $\begin{array}{l}\text { live } 2 \text { houses } \\
\text { from intersection }\end{array}$ & $\mathrm{b}, \mathrm{h}, \mathrm{j}$ & $\begin{array}{c}\text { increased } \\
\text { development } \\
\text { has increased } \\
\text { volume of traf }\end{array}$ & \begin{tabular}{|c} 
more \\
than \\
twice per \\
day
\end{tabular} & $\mathrm{c}, \mathrm{g}, \mathrm{h}$ & $\begin{array}{l}2-4 \\
\min \end{array}$ & 47906 & are@purdue.edu \\
\hline 107 & $\begin{array}{l}\text { At US } 52 \text { and } \\
\text { CR } 450 \mathrm{E}\end{array}$ & $\mathrm{a}, \mathrm{f}, \mathrm{g}$ & & $\mathrm{a}, \mathrm{b}$ & & $\begin{array}{c}\text { than } \\
\text { twice per }\end{array}$ & $\mathrm{d}, \mathrm{g}$ & $\begin{array}{l}6-8 \\
\min \end{array}$ & 47905 & \\
\hline 108 & $\begin{array}{l}\text { At US } 52 \text { and } \\
\text { Duncan Rd. }\end{array}$ & $\mathrm{i}$ & unsafe surface & $\mathrm{j}$ & $\begin{array}{c}\text { deep potholes } \\
\text { on west side of } \\
\text { Duncan Road } \\
\text { just so }\end{array}$ & $\begin{array}{l}3-5 \text { times } \\
\text { per week }\end{array}$ & $f, g$ & $\begin{array}{l}8-10 \\
\min \end{array}$ & 47904 & $\begin{array}{l}\text { paperdcl@minds } \\
\text { pring.com }\end{array}$ \\
\hline 109 & $\begin{array}{l}\text { At US } 52 \text { and } \\
\text { Hunter Rd. }\end{array}$ & $b, f$ & & $\mathrm{~b}, \mathrm{j}$ & Highway design & $\begin{array}{c}\text { more } \\
\text { than } \\
\text { twice per } \\
\text { day }\end{array}$ & $\begin{array}{c}\mathrm{c}, \mathrm{d}, \mathrm{e}, \mathrm{f}, \mathrm{g}, \\
\mathrm{h}, \mathrm{i}\end{array}$ & $\begin{array}{c}\text { less } \\
\text { than } 2 \\
\text { min }\end{array}$ & 47906 & tbb@purdue.edu \\
\hline 110 & $\begin{array}{c}\text { At US } 52 \text { and } \\
\text { Klondike }\end{array}$ & $a, b, c, f$ & & $\mathrm{~b}, \mathrm{c}, \mathrm{j}$ & $\begin{array}{c}\text { No turning lane } \\
\text { coming from } \\
\text { West (right on } \\
\text { to Klon }\end{array}$ & \begin{tabular}{|c} 
more \\
than \\
twice per \\
day
\end{tabular} & $\mathrm{c}, \mathrm{g}, \mathrm{h}$ & $\begin{array}{l}6-8 \\
\min \end{array}$ & 47906 & aggie99@gte.net \\
\hline 111 & $\begin{array}{l}\text { At US } 52 \text { and } \\
\text { Klondike }\end{array}$ & $\mathrm{a}, \mathrm{d}, \mathrm{e}, \mathrm{f}, \mathrm{i}$ & $\begin{array}{c}\text { other accidents at } \\
\text { location }\end{array}$ & $e, i, j$ & $\begin{array}{c}\text { difficult to see } \\
\text { stoplights at } \\
\text { certain times of } \\
\text { th }\end{array}$ & $\begin{array}{c}\text { twice per } \\
\text { day }\end{array}$ & $\frac{c, d, e, f, g,}{h}$ & None & 47906 & $\begin{array}{c}\text { bross11@hotmail } \\
\text {.com }\end{array}$ \\
\hline
\end{tabular}


Table B.28. Survey Results - 14B

\begin{tabular}{|c|c|c|c|c|c|c|c|c|c|c|}
\hline ID & Location & M & $\mathrm{F}$ & Age & Q9 A & Q9 B & Q9 C & Q9 D & Q9 E & Comment \\
\hline 104 & $\begin{array}{c}\text { At US } 52 \text { and } \\
\text { Brady Ln. }\end{array}$ & & $\mathrm{Y}$ & $|36-45|$ & $\mathrm{a}$ & $\mathrm{a}$ & $\mathrm{a}$ & $\mathrm{b}$ & $\mathrm{a}$ & $\begin{array}{l}\text { I feel the problem w/ intersection is when driving west on the Brady } \\
\text { lane extension, east of } 52 \mathrm{~S} \text {, it is } 2 \text { lanes. As you cross } 52 \text {, it remains } 2 \\
\text { lanes for a short distance, then merges as the cruves. I, my family, i } \\
\text { have witnesses multiple times where persons are run over the center } \\
\text { from someone traveling > speed limit, thru intersection, then past lane } \\
\text { of traffic. }\end{array}$ \\
\hline 105 & $\begin{array}{c}\text { At US } 52 \text { and } \\
\text { CR } 350 \mathrm{~S}\end{array}$ & & $\mathrm{Y}$ & $|46-55|$ & $\mathrm{a}$ & $\mathrm{a}$ & $\mathrm{a}$ & $\mathrm{a}$ & $\mathrm{a}$ & $\begin{array}{l}\text { stop lights on us } 52 \text { are hard to see when sun is low in the sky,the } \\
\text { sutters on them make them appear black and are only seen when } \\
\text { directly under them. }\end{array}$ \\
\hline 106 & $\begin{array}{c}\text { At US } 52 \text { and } \\
\text { CR } 400 \mathrm{~W}\end{array}$ & & $\mathrm{Y}$ & \begin{tabular}{c|}
$-=$ \\
Choo \\
se an \\
optio \\
$\mathrm{n}=-$
\end{tabular} & $\mathrm{a}$ & $\mathrm{a}$ & $\mathrm{a}$ & b & $\mathrm{b}$ & \\
\hline 107 & $\begin{array}{c}\text { At US } 52 \text { and } \\
\text { CR } 450 \mathrm{E}\end{array}$ & & $\mathrm{Y}$ & $|26-35|$ & b & $\mathrm{a}$ & $\mathrm{a}$ & b & $\mathrm{b}$ & $\begin{array}{l}\text { Usually during this time of year if corn is in those fields its hard to see } \\
\text { and anticpate if someone is going to run a yeild sign there and } 450 \mathrm{E} \& \\
500 \mathrm{~S} \text {. My ex-husband (my son's father) almost died at } 450 \mathrm{E} \& 450 \mathrm{~S} \\
\text { because he could see that a truck was going to run the yeild sign. No } \\
\text { action could be taken to avoid someone else's mistake. We were lucky; } \\
\text { someone else might not be. A four-way stop at both intersection would } \\
\text { slow traffic down alot. Its posted } 45 \mathrm{mph} \text { but its very easy to catch } \\
\text { yourself doing } 60 \mathrm{mph} \text {. }\end{array}$ \\
\hline 108 & $\begin{array}{c}\text { At US } 52 \text { and } \\
\text { Duncan Rd. }\end{array}$ & & $\mathrm{Y}$ & $65+$ & $\mathrm{a}$ & $\mathrm{a}$ & $\mathrm{a}$ & c & $\mathrm{c}$ & $\begin{array}{l}\text { Under \#3 there is no option for POTENTIAL problems experienced. } \\
\text { There are more problems at this intersection than indicated under \#4. } \\
\text { The right turn lane travelling east and turning south at the intersection } \\
\text { is too short. Drivers frequently pull into the far south } \\
\text { (emergency?)lane before they get to the MARRKED right turn lane, } \\
\text { surprising cars that are using the turn lane as marked, creating the } \\
\text { opportunity for collision with those who have taken the far right lane to } \\
\text { get ahead of the traffic waiting at the light. }\end{array}$ \\
\hline 109 & $\begin{array}{c}\text { At US } 52 \text { and } \\
\text { Hunter Rd. }\end{array}$ & $\mathrm{Y}$ & & $|46-55|$ & $\mathrm{a}$ & $\mathrm{a}$ & $\mathrm{a}$ & $\mathrm{a}$ & $\mathrm{a}$ & $\begin{array}{l}\text { There should be a deceleration lane and a median crossover on } 52 \text { for } \\
\text { westbound traffic turning onto Hunter Road. As it is, a person has to } \\
\text { slow down in the fast (left) lane and make a U-turn to get to the road. } \\
\text { It's become even more of an issue with the additional build-up of } \\
\text { Carrington Estates. }\end{array}$ \\
\hline 110 & $\begin{array}{c}\text { At US } 52 \text { and } \\
\text { Klondike }\end{array}$ & & $\mathrm{Y}$ & $|46-55|$ & $\mathrm{a}$ & $\mathrm{a}$ & $\mathrm{a}$ & $\mathrm{b}$ & $\mathrm{a}$ & $\begin{array}{l}\text { Many, many people RUN RED Lights at this intersection. School and } \\
\text { Lafayette Blind also cause further bottle-necking coming from the } \\
\text { South onto } 52 \text { West. We have witnessed SEVERAL semi's blowing } \\
\text { RED lights. Thank you for doing this - we need help out here. }\end{array}$ \\
\hline 111 & $\begin{array}{c}\text { At US } 52 \text { and } \\
\text { Klondike }\end{array}$ & $\mathrm{Y}$ & & $26-35 \mid$ & $\mathrm{a}$ & $\mathrm{a}$ & $\mathrm{a}$ & $\mathrm{c}$ & $\mathrm{a}$ & $\begin{array}{l}\text { Site should ask for improvements. I was involved in an accident at the } \\
\text { site several years ago. There have been SEVERAL since. I wrote a } \\
\text { letter to the highway dept. with suggestions and a request to change the } \\
\text { intersection. No reply and nothing happened. }\end{array}$ \\
\hline
\end{tabular}


Table B.29. Survey Results - 15A

\begin{tabular}{|c|c|c|c|c|c|c|c|c|c|c|}
\hline ID & Location & Q3 & Q3 (i) & Q4 & Q4 (j) & Q5 & Q6 & Q7 & Zip & E-mail \\
\hline 112 & $\begin{array}{l}\text { At US } 52 \text { and } \\
\text { McCormick } \\
\operatorname{Rd}(250 \mathrm{~W})\end{array}$ & $\mathrm{a}, \mathrm{f}$ & & $\mathrm{b}, \mathrm{h}$ & & $\begin{array}{c}\text { twice per } \\
\text { day }\end{array}$ & $\mathrm{c}, \mathrm{g}$ & $\begin{array}{c}\text { less } \\
\text { than } 2 \\
\text { min }\end{array}$ & 47906 & \\
\hline 113 & $\begin{array}{l}\text { At US } 52 \text { and } \\
\text { McCormick } \\
\operatorname{Rd}(250 \mathrm{~W})\end{array}$ & $\mathrm{a}, \mathrm{b}, \mathrm{c}, \mathrm{g}$ & & $\mathrm{b}, \mathrm{c}, \mathrm{h}$ & & $\begin{array}{l}3-5 \text { times } \\
\text { per week }\end{array}$ & $\mathrm{e}, \mathrm{f}, \mathrm{g}$ & $\begin{array}{c}\text { less } \\
\text { than } 2 \\
\text { min }\end{array}$ & 47906 & \\
\hline 114 & $\begin{array}{c}\text { At US } 52 \text { and } \\
\text { Moorehouse } \\
\text { Rd. }\end{array}$ & i & $\begin{array}{c}\text { Improperly timed } \\
\text { traffic lights }\end{array}$ & g & & $\begin{array}{c}\text { more } \\
\text { than } \\
\text { twice per } \\
\text { day }\end{array}$ & $\mathrm{c}, \mathrm{e}, \mathrm{g}$ & $\begin{array}{l}2-4 \\
\min \end{array}$ & 47971 & $\begin{array}{c}\text { jrzimmer@purdu } \\
\text { e.edu }\end{array}$ \\
\hline 115 & $\begin{array}{c}\text { At US } 52 \text { and } \\
\text { SR } 25\end{array}$ & $\mathrm{a}, \mathrm{f}, \mathrm{i}$ & $\begin{array}{c}\text { manny people } \\
\text { running red light } \\
\text { turning onto State } \\
\text { R }\end{array}$ & b & & $\begin{array}{c}\text { twice per } \\
\text { day }\end{array}$ & $\mathrm{b}, \mathrm{e}, \mathrm{g}, \mathrm{i}$ & None & 47906 & \\
\hline 116 & $\begin{array}{c}\text { At US } 52 \text { and } \\
\text { SR } 26\end{array}$ & $\mathrm{c}, \mathrm{f}$ & & c & & $\begin{array}{l}1-3 \text { times } \\
\text { per week }\end{array}$ & d & $\begin{array}{l}8-10 \\
\min \end{array}$ & 47905 & \\
\hline 117 & $\begin{array}{c}\text { At US } 52 \text { and } \\
\text { SR } 26\end{array}$ & $\mathrm{f}, \mathrm{h}$ & & $\mathrm{j}$ & $\begin{array}{l}\text { inconsiderate } \\
\text { drivers }\end{array}$ & $\begin{array}{c}\text { less than } \\
\text { once per } \\
\text { week }\end{array}$ & $\mathrm{h}$ & $\begin{array}{l}2-4 \\
\min \end{array}$ & 47923 & \\
\hline 118 & $\begin{array}{c}\text { At US } 52 \text { and } \\
\text { SR } 26\end{array}$ & $\mathrm{a}, \mathrm{f}$ & & $\mathrm{g}$ & & $\begin{array}{l}1-3 \text { times } \\
\text { per week }\end{array}$ & d & $\begin{array}{c}\text { less } \\
\text { than } 2 \\
\text { min }\end{array}$ & 47909 & $\begin{array}{l}\text { dave@americanpi } \\
\text { cnic.com }\end{array}$ \\
\hline
\end{tabular}


Table B.30. Survey Results - 15B

\begin{tabular}{|c|c|c|c|c|c|c|c|c|c|c|}
\hline ID & Location & M & F & Age & Q9 A & Q9 B & Q9 C & Q9 D & Q9 E & Comment \\
\hline 112 & $\begin{array}{l}\text { At US } 52 \text { and } \\
\text { McCormick } \\
\operatorname{Rd}(250 \mathrm{~W})\end{array}$ & & $\mathrm{Y}$ & $36-45$ & $\mathrm{a}$ & $\mathrm{a}$ & $\mathrm{a}$ & $\mathrm{b}$ & $\mathrm{a}$ & $\begin{array}{l}\text { It is very difficult to get through this intersection when driving from } \\
\text { McCormick across Hwy } 52 \text { to } 250 \mathrm{~W} \text { and back. It is also very difficult } \\
\text { to make left hand turns either direction due to the large volume of } \\
\text { traffic. Bethel Church, which is on the corner of McCormick and } 52 \\
\text { offers a daycare service and this creates a great deal of traffic added to } \\
\text { the difficult of crossing or turning onto } 52 \text {. }\end{array}$ \\
\hline 113 & $\begin{array}{l}\text { At US } 52 \text { and } \\
\text { McCormick } \\
\operatorname{Rd}(250 \mathrm{~W})\end{array}$ & $\mathrm{Y}$ & & $16-25$ & $\mathrm{a}$ & $\mathrm{a}$ & $\mathrm{a}$ & $\mathrm{b}$ & $\mathrm{a}$ & $\begin{array}{l}\text { The main concern for this intersection is that the major road is a } 4 \text { lane } \\
\text { divided highway with speeds of } 55 \mathrm{mph} \text {. for traffic on the minor road } \\
\text { (McCormick)to turn left onto US52 or through, there is difficulty } \\
\text { finding gaps in the traffic during peak hours. Often there are } \\
\text { platooning so gaps are sporadic. A traffic study should be done to see } \\
\text { if any warrants are fulfilled for possible flashing beacons or even a } \\
\text { signal, although signalization might not be needed. Good luck Brian } \\
\text { with your research. }\end{array}$ \\
\hline 114 & $\begin{array}{c}\text { At US } 52 \text { and } \\
\text { Moorehouse } \\
\text { Rd. }\end{array}$ & $\mathrm{Y}$ & & $36-45$ & $\mathrm{c}$ & $\mathrm{c}$ & $\mathrm{a}$ & c & c & $\begin{array}{l}\text { The traffic lights on U.S. } 52 \text { are timed improperly. All crossroads are } \\
\text { allowed a green light "on demand". One car at any intersection causes } \\
\text { lights to change almost instantaneously. This is a great contributor to } \\
\text { accidents, driver frustration, as well as a factor in encouraging U.S. } 52 \\
\text { drivers to run yellow and red lights. The intersections at Cumberland } \\
\text { (Wal-Mart), Morehouse, and Klondike are notorious for stopping } 4 \\
\text { lanes of traffic moving at } 55 \mathrm{MPH} \text { to allow one car through the } \\
\text { intersection. It is very apparent to me that this was the cause of the } \\
\text { fatality involving a semi-tractor trailer at Klondike Road \& } 52 \text { last } \\
\text { year. I see near collisions at all of these crossroads every day. Do the } \\
\text { morons at INDOT not understand the concept of synchronized traffic } \\
\text { lights? I would encourage them to take a drive down South Michigan } \\
\text { St. in South Bend or St. Rd. } 2 \text { through downtown LaPorte. }\end{array}$ \\
\hline 115 & $\begin{array}{l}\text { At US } 52 \text { and } \\
\quad \text { SR } 25\end{array}$ & $\mathrm{Y}$ & & $26-35$ & $\mathrm{a}$ & b & $\mathrm{a}$ & $\mathrm{a}$ & $\mathrm{a}$ & \\
\hline 116 & $\begin{array}{l}\text { At US } 52 \text { and } \\
\quad \text { SR } 26\end{array}$ & & $\mathrm{Y}$ & $36-45$ & $\mathrm{a}$ & a & $\mathrm{a}$ & $\mathrm{a}$ & $\mathrm{a}$ & \\
\hline 117 & $\begin{array}{c}\text { At US } 52 \text { and } \\
\text { SR } 26\end{array}$ & $\mathrm{Y}$ & & $65+$ & a & a & $\mathrm{a}$ & b & b & $\begin{array}{l}\text { It is not this location or any other location that is 'dangerous',,, it is the } \\
\text { 'drivers who don't care' that are dangerous! Ticket them. Stop them. } \\
\text { Get their attention somehow to change their attitude. }\end{array}$ \\
\hline 118 & $\begin{array}{l}\text { At US } 52 \text { and } \\
\quad \text { SR } 26\end{array}$ & $\mathrm{Y}$ & & $36-45$ & $\mathrm{a}$ & $\mathrm{a}$ & $\mathrm{a}$ & $\mathrm{a}$ & $\mathrm{b}$ & $\begin{array}{l}\text { As out of town people, on SR } 26 \text { westbound in the right hand lane, } \\
\text { approach the SR } 52 \text { intersection, they are surprised by the lane } \\
\text { reduction and quickly try to merge left. This has been this way from } \\
\text { years, and most doing the last minute merging are indeed from out of } \\
\text { town, and not familiar with the intersection. Some sort of advance } \\
\text { signage would help people avoid this last minute lane change, } \\
\text { especially since traffic backs up at this intersection. }\end{array}$ \\
\hline
\end{tabular}


Table B.31. Survey Results $-16 \mathrm{~A}$

\begin{tabular}{|c|c|c|c|c|c|c|c|c|c|c|}
\hline ID & Location & Q3 & Q3 (i) & Q4 & Q4 (j) & Q5 & Q6 & Q7 & Zip & E-mail \\
\hline 119 & $\begin{array}{l}\text { At US } 52 \text { and } \\
\text { SR } 26\end{array}$ & $a, f$ & & $g, j$ & $\begin{array}{l}\text { timing of the } \\
\text { stoplights }\end{array}$ & $\begin{array}{c}\text { twice per } \\
\text { day }\end{array}$ & $\mathrm{b}, \mathrm{g}$ & $\begin{array}{l}6-8 \\
\min \end{array}$ & 47970 & $\begin{array}{c}\text { chmath@worldne } \\
\text { t.att.net }\end{array}$ \\
\hline 120 & $\begin{array}{l}\text { At US } 52 \text { and } \\
\text { SR } 26\end{array}$ & $\mathrm{f}$ & & $\mathrm{b}, \mathrm{g}$ & & \begin{tabular}{|c|}
$\begin{array}{c}\text { more } \\
\text { than } \\
\text { twice per } \\
\text { day }\end{array}$ \\
\end{tabular} & $\mathrm{b}, \mathrm{f}$ & $\begin{array}{l}2-4 \\
\min \end{array}$ & 47904 & $\begin{array}{c}\text { jcbrawner@earthl } \\
\text { ink.net }\end{array}$ \\
\hline 121 & $\begin{array}{l}\text { At US } 52 \text { and } \\
\text { SR } 26\end{array}$ & $\mathrm{f}$ & & $\mathrm{j}$ & illegal turns & $\begin{array}{c}\text { once per } \\
\text { day }\end{array}$ & $\mathrm{f}$ & $\begin{array}{c}2-4 \\
\text { min }\end{array}$ & 47905 & \\
\hline 122 & $\begin{array}{l}\text { At US } 52 \text { and } \\
\text { SR } 38\end{array}$ & $\frac{a, b, c, f, g}{i}$ & $\begin{array}{c}\text { Simply } \\
\text { observations }\end{array}$ & $\mathrm{c}, \mathrm{j}$ & $\begin{array}{c}\text { Drivers } \sim \text { nothing } \\
\text { else }\end{array}$ & $\mid \begin{array}{c}\text { twice per } \\
\text { day }\end{array}$ & $\mathrm{b}, \mathrm{g}$ & $\begin{array}{c}\text { less } \\
\text { than } 2 \\
\text { min }\end{array}$ & 47904 & $\begin{array}{c}\text { RE1H8P9@aol.c } \\
\text { om }\end{array}$ \\
\hline 123 & $\begin{array}{l}\text { Columbia St. } \\
\text { Near 9th St. }\end{array}$ & $\mathrm{b}, \mathrm{e}$ & & $b, d, e, j$ & $\begin{array}{c}\text { Bumps make } \\
\text { very fightening } \\
\text { stops }\end{array}$ & $\begin{array}{c}\text { twice per } \\
\text { day }\end{array}$ & $\mathrm{c}, \mathrm{g}$ & $\begin{array}{l}2-4 \\
\min \end{array}$ & 47909 & $\begin{array}{c}\text { rmgee@purdue.e } \\
\mathrm{du}\end{array}$ \\
\hline 124 & $\begin{array}{c}\text { CR } 200 \mathrm{~N} \\
\text { Near E. } \\
\text { County Line } \\
\text { Rd. }\end{array}$ & $\mathrm{i}$ & drove on it & $\mathrm{a}, \mathrm{j}$ & $\begin{array}{c}\text { large/deep } \\
\text { potholes and } \\
\text { weeds }\end{array}$ & $\begin{array}{l}3-5 \text { times } \\
\text { per week }\end{array}$ & $\mathrm{d}, \mathrm{g}, \mathrm{h}$ & $\begin{array}{l}6-8 \\
\min \end{array}$ & 47905 & $\begin{array}{c}\text { bigdavenel@aol.c } \\
\text { om }\end{array}$ \\
\hline 125 & $\begin{array}{c}\text { CR } 700 \mathrm{~N} \\
\text { Near Railroad } \\
\text { St. }\end{array}$ & $\mathrm{i}$ & I drive by daily & $\mathrm{a}, \mathrm{j}$ & $\begin{array}{l}\text { weeds are so } \\
\text { tall they are } \\
\text { laying on the } \\
\text { road bloc }\end{array}$ & $\begin{array}{c}\text { more } \\
\text { than } \\
\text { twice per } \\
\text { day }\end{array}$ & $\mathrm{b}, \mathrm{f}, \mathrm{g}, \mathrm{h}$ & None & 47905 & \\
\hline 126 & $\begin{array}{c}\text { Division Rd. } \\
\text { Near CR } 500 \\
\text { W }\end{array}$ & $\mathrm{b}$ & & $\mathrm{a}$ & & \begin{tabular}{|c|} 
more \\
than \\
twice per \\
day
\end{tabular} & $\mathrm{a}, \mathrm{d}, \mathrm{h}, \mathrm{i}$ & $\begin{array}{c}\text { less } \\
\text { than } 2 \\
\text { min }\end{array}$ & 47906 & \\
\hline 127 & $\begin{array}{l}\text { Grant Rd. } \\
\text { Near Pretty } \\
\text { Prairie Rd. }\end{array}$ & $\mathrm{a}, \mathrm{f}$ & & $\mathrm{b}$ & & $\begin{array}{c}\text { more } \\
\text { than } \\
\text { twice per } \\
\text { day }\end{array}$ & $\mathrm{d}, \mathrm{e}, \mathrm{f}, \mathrm{g}$ & None & 47920 & \\
\hline
\end{tabular}


Table B.32. Survey Results - 16B

\begin{tabular}{|c|c|c|c|c|c|c|c|c|c|c|}
\hline ID & Location & M & $\mathrm{F}$ & Age & Q9 A & Q9 B & Q9 C & Q9 D & Q9 E & Comment \\
\hline 119 & $\begin{array}{l}\text { At US } 52 \text { and } \\
\text { SR } 26\end{array}$ & $\mathrm{Y}$ & & $56-65$ & a & a & a & c & $\mathrm{b}$ & $\begin{array}{l}\text { westbound traffic is the heaviest 3:00 to3:30 pm because of area } \\
\text { factories letting out.the heavier traffic is backed up due to timing of } \\
\text { signals.thelighter traffic on the opposite side have more time with } \\
\text { signals than the backed up side .all the way around sagamore is like is } \\
\text { at every stoplight.it's not traffic it's the signals' }\end{array}$ \\
\hline 120 & $\begin{array}{l}\text { At US } 52 \text { and } \\
\quad \text { SR } 26\end{array}$ & $\mathrm{Y}$ & & $26-35$ & a & a & $\mathrm{a}$ & $\mathrm{a}$ & $\mathrm{a}$ & $\begin{array}{l}\text { This intersection needs a more free flowing travel could possibly } \\
\text { change the time of the lights especially at peak periods then change } \\
\text { them back for non peak periods or by some other means. Maybe make } \\
\text { this intersection a two lane like the teal road and } 52 \text { intersection so } \\
\text { more cars can go through at a time. or at least be able to turn with the } \\
\text { oncoming traffic. like some of the other intersections. }\end{array}$ \\
\hline 121 & $\begin{array}{c}\text { At US } 52 \text { and } \\
\text { SR } 26\end{array}$ & & $\mathrm{Y}$ & $46-55$ & $\mathrm{~b}$ & a & a & $\mathrm{b}$ & $\mathrm{b}$ & $\begin{array}{l}\text { People in the left turn lane on SR } 26 \text { (going west) at the Sagamore } \\
\text { Pkwy intersection often stop the lane of traffic with the turn arrow in } \\
\text { order to pull into the Subway store back parking area. This causes the } \\
\text { lane of traffic that should be moving with the green arrow to stop and } \\
\text { miss the light or rush on through even though the arrow as ended. I } \\
\text { suggest the median divider be extended making this illegal turn } \\
\text { impossible. This would keep the traffic moving through this busy } \\
\text { intersection. }\end{array}$ \\
\hline 122 & $\begin{array}{c}\text { At US } 52 \text { and } \\
\text { SR } 38\end{array}$ & $\mathrm{Y}$ & & $36-45$ & a & $\mathrm{b}$ & $\mathrm{b}$ & c & a & $\begin{array}{l}* * * * \text { Simple enforcement of laws already on the books would suffice } \\
* * * * \\
* * * * \text { Re-examine drivers understanding of what traffic signal colors } \\
\text { actually mean**** } \\
* * * * \text { Do what you say and say what you do (enforcement)-ask any } \\
\text { ISO9001/9002 company**** }\end{array}$ \\
\hline 123 & $\begin{array}{l}\text { Columbia St. } \\
\text { Near 9th St. }\end{array}$ & $\mathrm{Y}$ & & $16-25$ & a & $\mathrm{b}$ & a & $\mathrm{b}$ & $\mathrm{b}$ & $\begin{array}{l}\text { Is there anyway I can see a list of troubled areas. I am doing a report on } \\
\text { road conditoins in the county and any help is much appreciated. Thank } \\
\text { You, Ryan }\end{array}$ \\
\hline 124 & $\begin{array}{l}\text { CR } 200 \mathrm{~N} \\
\text { Near E. } \\
\text { County Line } \\
\text { Rd. }\end{array}$ & $\mathrm{Y}$ & & $46-55$ & a & a & $\mathrm{b}$ & $\mathrm{b}$ & $\mathrm{b}$ & $\begin{array}{l}\text { On the survey, I believe that you need a box for a short description of } \\
\text { problem. Not all dagers need to have a crash to make them dangerous. } \\
\text { The one that I list has had at least three minor ones in the past few } \\
\text { years or so. }\end{array}$ \\
\hline 125 & $\begin{array}{c}\text { CR } 700 \mathrm{~N} \\
\text { Near Railroad } \\
\text { St. }\end{array}$ & $\mathrm{Y}$ & & $16-25$ & a & a & a & a & a & $\begin{array}{l}\text { I LIVE JUST DOWN THE ROAD FROM THIS AREA IT IS } \\
\text { NARROW ENOUGH THAT ON A GOOD THERE IS NOT MUCH } \\
\text { ROOM FOR TWO CARS TO PASS. WITH THE WEEDS LIKE } \\
\text { THEY ARE IT IS PRETTY MUCH ONE LANE }\end{array}$ \\
\hline 126 & $\begin{array}{c}\text { Division Rd. } \\
\text { Near CR } 500 \\
\text { W }\end{array}$ & $\mathrm{Y}$ & & $36-45$ & $\mathrm{a}$ & a & $\mathrm{a}$ & $\mathrm{b}$ & a & A blind spot exists in passing zone due to dip in road. \\
\hline 127 & $\begin{array}{l}\text { Grant Rd. } \\
\text { Near Pretty } \\
\text { Prairie Rd. }\end{array}$ & $\mathrm{Y}$ & & $26-35$ & $\mathrm{a}$ & a & a & $\mathrm{b}$ & $\mathrm{b}$ & $\begin{array}{l}\text { The speed in the curves on Grant Road between Americus and Pretty } \\
\text { Praire Road is posted at } 50 \mathrm{mph} \text { and every body thinks they have to run } \\
\text { that posted speed. And when the go around these curves at } 50 \text { plus } \\
\text { mph they run over the center yellow line usaully in your lane I have } \\
\text { seen two wrecks in the last } 6 \text { months one of them was a head on } \\
\text { collosion Then you got the speed posted on pretty praire road going to } \\
\text { Battle Ground } 45 \mathrm{mph} \text { and it is a straight road It don't make any sense! }\end{array}$ \\
\hline
\end{tabular}


Table B.33. Survey Results - 17A

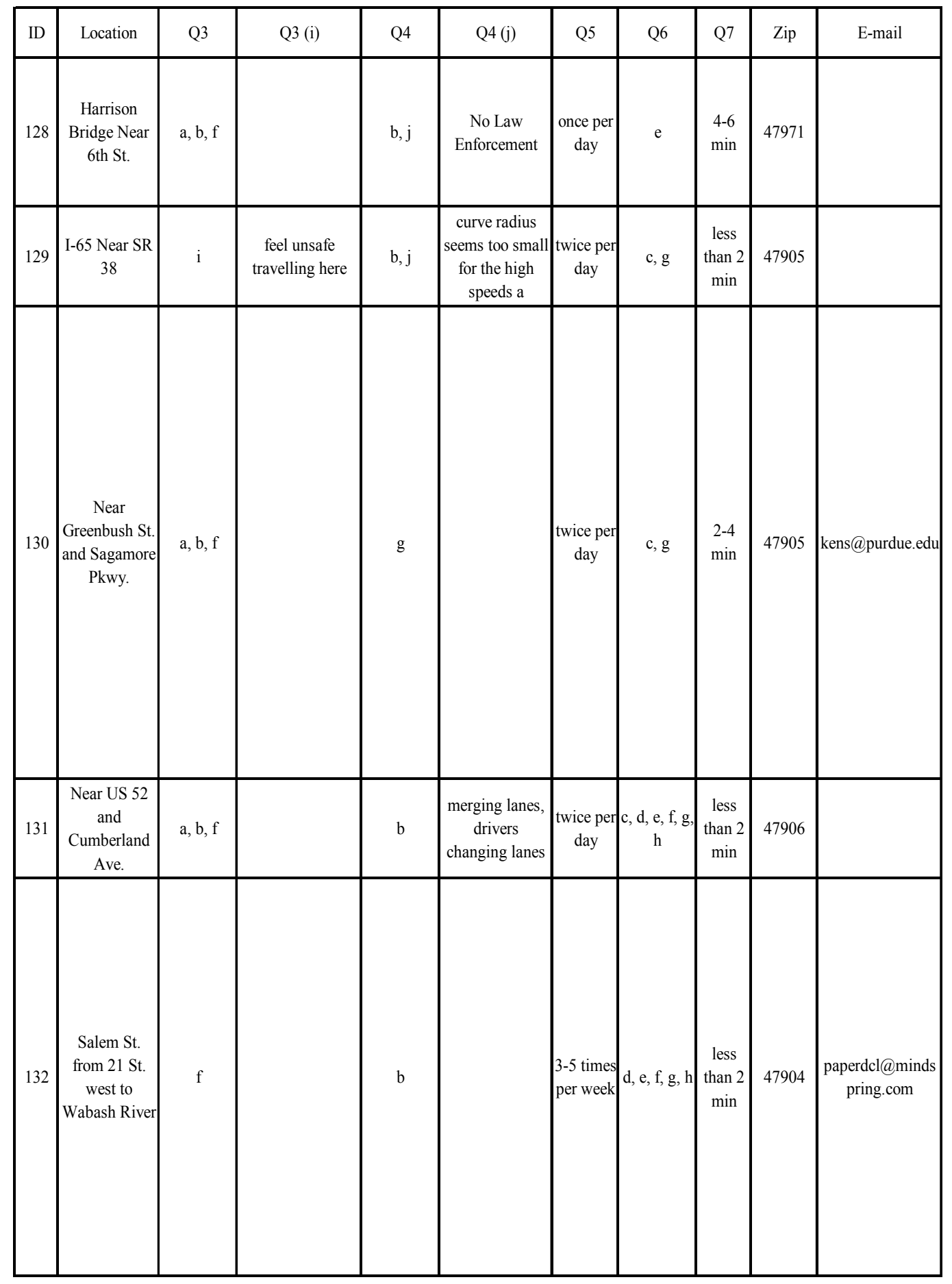


Table B.34. Survey Results - 17B

\begin{tabular}{|c|c|c|c|c|c|c|c|c|c|c|}
\hline ID & Location & M & $\mathrm{F}$ & Age & Q9 A & Q9 B & Q9 C & Q9 D & Q9 E & Comment \\
\hline 128 & $\begin{array}{l}\text { Harrison } \\
\text { Bridge Near } \\
\text { 6th St. }\end{array}$ & $\mathrm{Y}$ & & $36-45$ & $\mathrm{c}$ & $\mathrm{b}$ & b & $\mathrm{b}$ & c & $\begin{array}{l}\text { Traffic speed on the Harrison Bridge is unbelievably dangerous. } \\
\text { Posted speed limit is } 35 \mathrm{MPH} \text {. Traffic moves at } 45 \text { to } 65 \mathrm{MPH} \\
\text { regularly and then funnels into a residential area. Lafayette cops are } \\
\text { nowhere to be found. Issuing speeding tickets on Union/Salem at 6th } \\
\text { street would be like shooting fish in a barrel. }\end{array}$ \\
\hline 129 & $\begin{array}{c}\text { I- } 65 \text { Near SR } \\
38\end{array}$ & $\mathrm{Y}$ & & $16-25$ & $\mathrm{c}$ & b & $\mathrm{a}$ & b & $\mathrm{c}$ & $\begin{array}{l}\text { clickable map hard to use...survey is good, although there were a } \\
\text { couple of questions where I felt the responses were inadequate }\end{array}$ \\
\hline 130 & $\begin{array}{c}\text { Near } \\
\text { Greenbush St. } \\
\text { and Sagamore } \\
\text { Pkwy. }\end{array}$ & $\mathrm{Y}$ & & $46-55$ & $\mathrm{a}$ & $\mathrm{a}$ & $\mathrm{a}$ & $\mathrm{a}$ & $\mathrm{a}$ & $\begin{array}{l}\text { Traffic eastbound on Greenbush queues up in long lines waiting for the } \\
\text { signal at Sagamore Pkwy. At rush hours it is common for traffic } \\
\text { waiting for the Sagamore stop light to extend all the way back to } \\
\text { Elmwood Ave intersection. Two problems basically: no right turn lane } \\
\text { at this intersection so ALL cars except left turns queue up in a single } \\
\text { long line. Second problem: drivers way back in line can't see parked } \\
\text { cars ahead of them, so later on they discover they have to get over to } \\
\text { the left lane to bypass the parked cars before moving to the right again } \\
\text { to get out of the left turning lane. Not only are these drivers frustrated, } \\
\text { but they may get sideswiped by cars already in the left turn lane who } \\
\text { ignore their efforts to get out from behind the parked cars. I myself } \\
\text { have almost been sideswiped this way. Oh, problem 3: the red light } \\
\text { for Greenbush is so long, it can take } 3 \text { to } 4 \text { cycles for an eastbound car } \\
\text { to cross Sagamore, which can be more than a } 5 \text { minute wait at rush } \\
\text { hour. To solve the problem: add a right turn lane, ban parking on } \\
\text { Greenbush between Elmwood and Sagamore, and decrease stoplight cy }\end{array}$ \\
\hline 131 & $\begin{array}{c}\text { Near US } 52 \\
\text { and } \\
\text { Cumberland } \\
\text { Ave. }\end{array}$ & $\mathrm{Y}$ & & $56-65$ & $\mathrm{a}$ & $\mathrm{a}$ & $\mathrm{a}$ & $\mathrm{a}$ & $\mathrm{a}$ & $\begin{array}{l}\text { Some drivers seem unaware of merging lanes; most race others in } \\
\text { northbound righthand merging lane to beat the other traffic to the } \\
\text { merge point }\end{array}$ \\
\hline 132 & $\begin{array}{c}\text { Salem St. } \\
\text { from } 21 \mathrm{St} . \\
\text { west to } \\
\text { Wabash River }\end{array}$ & & $\mathrm{Y}$ & $65+$ & $\mathrm{a}$ & $\mathrm{a}$ & $\mathrm{a}$ & $\mathrm{a}$ & a & $\begin{array}{l}\text { Drivers going west on Union then dipping down onto Salem RARELY } \\
\text { go } 25 \mathrm{MPH} \text { which is the posted speed limit. Part of the confusion may } \\
\text { lie in the fact that Union Street going east is } 35 \mathrm{MPH} \text { while Ssalem } \\
\text { going west is } 25 \mathrm{MPH} \text {. The only place I have ever had an accident } \\
\text { was turning north off Salem onto } 19 \text { th Street and being rear-ended by a } \\
\text { car that came around the curve from } 21 \text { st Street too fast to slow down } \\
\text { in time to avoid hitting me as I made the turn. Fast driving cars along } \\
\text { this stretch of road tend to switch lanes back and forth rapidly to get } \\
\text { ahead of cars that are going the posted } 25 \mathrm{MPH} \text {. This is complicated } \\
\text { by cars trying to turn onto Salem from cross streets and pulling out of } \\
\text { the Huntington Bank exit or the one across the street just before } 18 \text { th } \\
\text { Street, expecting traffic to be going slower than it is or than the } \\
\text { speeders who are dodging in and out of lanes. }\end{array}$ \\
\hline
\end{tabular}


Table B.35. Survey Results - 18A

\begin{tabular}{|c|c|c|c|c|c|c|c|c|c|c|}
\hline ID & Location & Q3 & Q3 (i) & Q4 & Q4 (j) & Q5 & Q6 & Q7 & Zip & E-mail \\
\hline 133 & $\begin{array}{c}\text { South River } \\
\text { Rd. Near } \\
\text { Newman Rd. }\end{array}$ & $\mathrm{a}, \mathrm{c}, \mathrm{f}$ & & $b, c, j$ & slope of road & $\begin{array}{c}\text { twice per } \\
\text { day }\end{array}$ & $\mathrm{c}, \mathrm{d}, \mathrm{f}, \mathrm{g}$ & $\begin{array}{r}6-8 \\
\min \end{array}$ & 47906 & \\
\hline . & $\begin{array}{c}\text { South St. Near } \\
\text { 2nd St. }\end{array}$ & $\mathrm{a}, \mathrm{b}, \mathrm{f}, \mathrm{g}$ & & $\mathrm{d}, \mathrm{j}$ & $\begin{array}{l}\text { Two conflicting } \\
\text { lane change } \\
\text { directions. }\end{array}$ & $\begin{array}{c}\text { once per } \\
\text { day }\end{array}$ & $\mathrm{c}$ & None & 47993 & $\begin{array}{c}\text { dl_white2001@y } \\
\text { ahoo.com }\end{array}$ \\
\hline 135 & $\begin{array}{c}\text { SR 26 } \\
\text { Between 2nd } \\
\text { and 3rd St }\end{array}$ & $\mathrm{b}$ & & $\mathrm{j}$ & $\begin{array}{l}\text { Lanes curved } \\
\text { and people not } \\
\text { getting over } \\
\text { correctly }\end{array}$ & $\begin{array}{l}3-5 \text { times } \\
\text { per week }\end{array}$ & $\mathrm{c}, \mathrm{g}$ & None & 47944 & $\begin{array}{c}\text { katie_purdue@ya } \\
\text { hoo.com }\end{array}$ \\
\hline 136 & $\begin{array}{c}\text { SR 26 } \\
\text { Between I-65 } \\
\text { and US } 52\end{array}$ & $\mathrm{i}$ & two many lights & $\mathrm{j}$ & two many lights & $\begin{array}{c}\text { twice per } \\
\text { day }\end{array}$ & None & $\begin{array}{l}6-8 \\
\min \end{array}$ & 47905 & $\begin{array}{c}\text { larry47905@hom } \\
\text { e.com }\end{array}$ \\
\hline 137 & $\begin{array}{c}\text { SR } 26 \\
\text { between US } \\
52 \text { and CR } \\
500 \mathrm{E}\end{array}$ & $\mathrm{f}, \mathrm{i}$ & $\begin{array}{l}\text { Lights improperly } \\
\text { timed }\end{array}$ & g & & 1-3 times & $\mathrm{f}$ & $\begin{array}{l}4-6 \\
\min \end{array}$ & 47971 & \\
\hline 138 & $\begin{array}{c}\text { SR } 26 \text { Near } \\
\text { Tapawingo } \\
\text { Dr. }\end{array}$ & $\mathrm{f}, \mathrm{i}$ & Use it every day & $\mathrm{j}$ & $\begin{array}{c}\text { odd } \\
\text { construction of } \\
\text { divider }\end{array}$ & $\begin{array}{c}\text { twice per } \\
\text { day }\end{array}$ & $\mathrm{d}, \mathrm{g}$ & $\begin{array}{c}\text { less } \\
\text { than } 2 \\
\text { min }\end{array}$ & 47906 & $\begin{array}{c}\text { sellison@nlci.co } \\
\text { m }\end{array}$ \\
\hline 139 & $\begin{array}{c}\text { SR } 28 \text { Near } \\
\text { Railroad }\end{array}$ & $\mathrm{f}$ & & $\mathrm{j}$ & $\begin{array}{c}\text { train blocking } \\
\text { road too long } \\
\text { cars race to get } \\
\text { acro }\end{array}$ & $\begin{array}{c}\text { less than } \\
\text { once per } \\
\text { week }\end{array}$ & d & $\begin{array}{l}4-6 \\
\min \end{array}$ & 47918 & \\
\hline
\end{tabular}


Table B.36. Survey Results - 18B

\begin{tabular}{|c|c|c|c|c|c|c|c|c|c|c|}
\hline ID & Location & M & $\mathrm{F}$ & Age & Q9 A & Q9 B & Q9 C & Q9 D & Q9 E & Comment \\
\hline 133 & $\begin{array}{l}\text { South River } \\
\text { Rd. Near } \\
\text { Newman Rd. }\end{array}$ & $\mathrm{Y}$ & & $36-45$ & $\mathrm{a}$ & b & $\mathrm{a}$ & $\mathrm{b}$ & $\mathrm{c}$ & \\
\hline 134 & $\begin{array}{l}\text { South St. Near } \\
\text { 2nd St. }\end{array}$ & $\mathrm{Y}$ & & $46-55$ & $\mathrm{a}$ & $\mathrm{a}$ & $\mathrm{a}$ & $\mathrm{a}$ & $\mathrm{a}$ & $\begin{array}{l}\text { I have notitfied the city of Lafayette about this dangerous lane change, } \\
\text { several times. After the fourth or fifth E-mail I finally got a reply that it } \\
\text { would be looked at. When you come across the bridge from W. } \\
\text { Lafayette onto South street, you come up to a stop light at } 2 \text { nd street. } \\
\text { After that light there is a dotted white line that directs the far left and } \\
\text { middle lanes to go back left, after the constuction for the parking } \\
\text { garage. This white dotted line is very faded, and doesn't show up very } \\
\text { good. There is also a very large white arrow that shows this lane to go } \\
\text { straight only. I see a near miss here almost every morning. The drivers } \\
\text { in this town have enough trouble without having two different orders a } \\
\text { the same place in the lane. My addvice for Channel } 18 \text { is to drive east } \\
\text { bound on this road at about 7:45 A.M. any weekday morning and I am } \\
\text { sure you will see what I am talking about. }\end{array}$ \\
\hline 135 & $\begin{array}{c}\text { SR 26 } \\
\text { Between 2nd } \\
\text { and 3rd St }\end{array}$ & & $\mathrm{Y}$ & $|16-25|$ & $\mathrm{a}$ & $\mathrm{a}$ & $\mathrm{a}$ & $\mathrm{a}$ & $\mathrm{a}$ & $\begin{array}{l}\text { The lanes need to be marked clearer so that people will know to get } \\
\text { over and then to get back over into their lane. It has caused many near } \\
\text { accidents. }\end{array}$ \\
\hline 136 & $\begin{array}{c}\text { SR } 26 \\
\text { Between I-65 } \\
\text { and US } 52\end{array}$ & $\mathrm{Y}$ & & $|56-65|$ & $\mathrm{a}$ & $\mathrm{a}$ & $\mathrm{a}$ & $\mathrm{c}$ & $\mathrm{b}$ & $\begin{array}{l}\text { Eliminate the cross traffic except at Creasy Lane, Farabee, Wal_Mart } \\
\text { etc and use turn lane for } 360 \text { or round a bouts instead of traffic lights. } \\
\text { By passing the normal turn lanes, you add a few minutes for a locatin } \\
\text { but save on travel time to the city. }\end{array}$ \\
\hline 137 & $\begin{array}{l}\text { SR } 26 \\
\text { between US } \\
52 \text { and CR } \\
500 \mathrm{E}\end{array}$ & $\mathrm{Y}$ & & $|36-45|$ & $\mathrm{c}$ & $\mathrm{c}$ & $\mathrm{a}$ & $\mathrm{b}$ & c & $\begin{array}{l}\text { Poor urban planning has contributed greatly to the bottlenecks on St. } \\
\text { Rd. 26. Synchronized lights would help greatly. The "greenlight on } \\
\text { demand" system around town has outlived its purpose. (Where } \\
\text { crossroad traffic causes traffic lights to change, rather than having } \\
\text { synchronized lights.) }\end{array}$ \\
\hline 138 & $\begin{array}{l}\text { SR } 26 \text { Near } \\
\text { Tapawingo } \\
\text { Dr. }\end{array}$ & $\mathrm{Y}$ & & $65+$ & $\mathrm{a}$ & $\mathrm{a}$ & $\mathrm{a}$ & $\mathrm{a}$ & $\mathrm{a}$ & \\
\hline 139 & $\begin{array}{c}\text { SR } 28 \text { Near } \\
\text { Railroad }\end{array}$ & & $\mathrm{Y}$ & $46-55$ & $\mathrm{a}$ & $\mathrm{a}$ & $\mathrm{a}$ & $\mathrm{a}$ & $\mathrm{a}$ & $\begin{array}{l}\text { the train that gose to staly plant blocks too many roads for too long a } \\
\text { time ,causing drivers to race across or turn around in the middel of the } \\
\text { road. }\end{array}$ \\
\hline
\end{tabular}


Table B.37. Survey Results - 19A

\begin{tabular}{|c|c|c|c|c|c|c|c|c|c|c|}
\hline ID & Location & Q3 & Q3 (i) & Q4 & Q4 (j) & Q5 & Q6 & Q7 & Zip & E-mail \\
\hline . & $\begin{array}{c}\text { SR } 38 \text { Near } \\
\text { Point East } \\
\text { Trailer Park }\end{array}$ & $\mathrm{f}$ & & $\mathrm{b}, \mathrm{h}, \mathrm{j}$ & $\begin{array}{l}\text { NO TURN } \\
\text { LANE }\end{array}$ & \begin{tabular}{|c} 
\\
\\
more \\
than \\
twice per \\
day
\end{tabular} & $\begin{array}{l}\text { a, b, c, d, } \\
e, f, g, h, i\end{array}$ & $\begin{array}{c}\text { less } \\
\text { than } 2 \\
\text { min }\end{array}$ & 47905 & $\begin{array}{c}\text { last_female@hot } \\
\text { mail.com }\end{array}$ \\
\hline 141 & \begin{tabular}{|c} 
Tyler Rd. \\
Near CR 900 \\
N
\end{tabular} & $\mathrm{a}, \mathrm{c}, \mathrm{f}, \mathrm{g}$ & & $\mathrm{b}, \mathrm{c}, \mathrm{i}$ & & $\begin{array}{l}1-3 \text { times } \\
\text { per week }\end{array}$ & $\begin{array}{c}b, c, d, e, f, \\
g, h\end{array}$ & None & 47905 & $\begin{array}{c}\text { bowhunter@ique } \\
\text { st.net }\end{array}$ \\
\hline 142 & $\begin{array}{c}\text { US } 52 \text { at } \\
\text { Klondike and } \\
\text { Moorehouse }\end{array}$ & $\mathrm{i}$ & $\begin{array}{c}\text { The lights change } \\
\text { too fast }\end{array}$ & g & & $\begin{array}{l}3-5 \text { times } \\
\text { per week }\end{array}$ & None & None & 47942 & \\
\hline 143 & $\begin{array}{c}\text { US } 52 \\
\text { between W.L. } \\
\text { \& Fowler }\end{array}$ & $\mathrm{a}, \mathrm{b}, \mathrm{f}, \mathrm{i}$ & $\begin{array}{l}\text { No traffic law } \\
\text { enforcement }\end{array}$ & $b, i, j$ & $\begin{array}{l}\text { No law } \\
\text { enforcement }\end{array}$ & $\begin{array}{c}\text { more } \\
\text { than } \\
\text { twice per } \\
\text { day }\end{array}$ & $\mathrm{c}, \mathrm{g}$ & $\begin{array}{l}2-4 \\
\min \end{array}$ & 47971 & \\
\hline 144 & $\begin{array}{l}\text { US } 52 \text { Near } \\
\text { Duncan Rd. }\end{array}$ & $\mathrm{a}, \mathrm{b}, \mathrm{c}, \mathrm{f}$ & & $\mathrm{b}, \mathrm{c}, \mathrm{i}, \mathrm{j}$ & $\begin{array}{c}\text { Poor Snow } \\
\text { Removal }\end{array}$ & $\begin{array}{l}3-5 \text { times } \\
\text { per week }\end{array}$ & $\mathrm{f}$ & $\begin{array}{l}4-6 \\
\min \end{array}$ & 47971 & \\
\hline 145 & $\begin{array}{l}\text { US } 52 \text { Near } \\
\text { Jefferson } \\
\text { Commons }\end{array}$ & $\mathrm{a}, \mathrm{f}$ & & $b, j$ & $\begin{array}{c}\text { Part of the } \\
\text { problem is half } \\
\text { the drivers do } \\
45 \mathrm{mph}\end{array}$ & $\begin{array}{c}\text { more } \\
\text { than } \\
\text { twice per } \\
\text { day }\end{array}$ & $\begin{array}{c}\mathrm{a}, \mathrm{c}, \mathrm{d}, \mathrm{e}, \mathrm{f} \\
\mathrm{g}, \mathrm{h}, \mathrm{i}\end{array}$ & $\begin{array}{l}2-4 \\
\min \end{array}$ & 47906 & $\begin{array}{c}\text { hollyefranks@yah } \\
\text { oo.com }\end{array}$ \\
\hline
\end{tabular}


Table B.38. Survey Results - 19B

\begin{tabular}{|c|c|c|c|c|c|c|c|c|c|c|}
\hline ID & Location & M & $\mathrm{F}$ & Age & Q9 A & Q9 B & Q9 C & Q9 D & Q9 E & Comment \\
\hline 140 & $\begin{array}{l}\text { SR } 38 \text { Near } \\
\text { Point East } \\
\text { Trailer Park }\end{array}$ & & $\mathrm{Y}$ & $|26-35|$ & $\mathrm{a}$ & b & $\mathrm{a}$ & $\mathrm{c}$ & $\mathrm{c}$ & $\begin{array}{l}\text { I live in Point East and travel st rd. } 38 \text { several times everyday. I cannot } \\
\text { count the number of times I have almost had very bad accidents } \\
\text { because someone behind me is either going to fast, tailgating, or just } \\
\text { not paying attention. If you are traveling west on } 38 \text { going to Point } \\
\text { East Trailor Park, There is no turn lane for east bound traffic, so you } \\
\text { must try to stop traffic behind you and hope to God that they see that } \\
\text { you are waiting to turn left. There is however a turn lane for the east } \\
\text { bound side. You can take your chances using it if you want but there } \\
\text { are no gauruntees you wont get hit by on-coming traffic. Alot of } \\
\text { people seem to think that this lane is for both sides of the highway but } \\
\text { it clearly states ONLY (with an arrow) for the other side! And with } \\
\text { SIA right there durring shift changes and people getting off of work } \\
\text { that just want to get home in a hurry, it makes turning left into Point } \\
\text { East almost impossible without having an accident. I get semi trucks } \\
\text { behind me blowing thier horns and cars screaching tires, and an } \\
\text { occasional obscene yell from a driver. WHEN will Tippecanoe county } \\
\text { Sincerely, Teresa L. Evans }\end{array}$ \\
\hline 141 & $\begin{array}{l}\text { Tyler Rd. } \\
\text { Near CR } 900 \\
\text { N }\end{array}$ & Y & & $46-55$ & $\mathrm{a}$ & $\mathrm{a}$ & $\mathrm{a}$ & $\mathrm{b}$ & b & $\begin{array}{l}\text { You list this as Pretty Prairie but it is Tyler Road. When the road is } \\
\text { the least bit wet there is an accident. It is somewhat like the road by } \\
\text { Clegg Gardens of which has been coated and is now safe. There are } \\
\text { many accidents on Tyler and many go unreported. My daughter lives } \\
\text { there on "Dead Mans Curve" so I hear a lot from her but I have been } \\
\text { there when it has happened. The county has been asked and they said } \\
\text { the coating like by the Clegg Gardens is too expensive to put on it. } \\
\text { What is a life worth and the property damaged. }\end{array}$ \\
\hline 142 & $\begin{array}{c}\text { US } 52 \text { at } \\
\text { Klondike and } \\
\text { Moorehouse }\end{array}$ & $\mathrm{Y}$ & & $|46-55|$ & b & $\mathrm{b}$ & $\mathrm{a}$ & $\mathrm{b}$ & $\mathrm{c}$ & $\begin{array}{l}\text { The Klondike and Moorehouse Road lights used to have a delay after a } \\
\text { car pulled up. Now they trigger switch to yellow. The yellows are not } \\
\text { long enough to safely stop a semi doing the speed limit or under. }\end{array}$ \\
\hline 143 & $\begin{array}{c}\text { US } 52 \\
\text { between W.L. } \\
\text { \& Fowler }\end{array}$ & $\mathrm{Y}$ & & $36-45$ & $\mathrm{c}$ & $\mathrm{c}$ & $\mathrm{a}$ & $\mathrm{b}$ & $\mathrm{c}$ & $\begin{array}{l}\text { The lack of police presence contributes greatly to the anarchy present } \\
\text { on U.S. } 52 \text { West. It is also a heavily used alternate route for I-65. I } \\
\text { regularly see Tippecanoe, Benton County, and State Police officers } \\
\text { ignoring speed limits as well as ignoring other drivers' excessive speed } \\
\text { and traffic infractions. }\end{array}$ \\
\hline 144 & $\begin{array}{l}\text { US } 52 \text { Near } \\
\text { Duncan Rd. }\end{array}$ & $\mathrm{Y}$ & & $36-45$ & $\mathrm{c}$ & b & $\mathrm{a}$ & $\mathrm{b}$ & $\mathrm{c}$ & $\begin{array}{l}\text { Poor snow removal makes the U.S. } 52 \text { hill very dangerous in snowy } \\
\text { weather. Road crews need to remove snow \& salt roads as the snow is } \\
\text { coming down, NOT after } 20 \text { cars are already in the ditch. They could } \\
\text { take some lessons from northern Indiana crews. }\end{array}$ \\
\hline 145 & $\begin{array}{l}\text { US } 52 \text { Near } \\
\text { Jefferson } \\
\text { Commons }\end{array}$ & & $\mathrm{Y}$ & $|16-25|$ & $\mathrm{c}$ & $\mathrm{a}$ & $\mathrm{a}$ & $\mathrm{b}$ & $\mathrm{a}$ & \\
\hline
\end{tabular}


Table B.39. Survey Responses - 20A

\begin{tabular}{|c|c|c|c|c|c|c|c|c|c|c|}
\hline ID & Location & Q3 & Q3 (i) & Q4 & Q4 (j) & Q5 & Q6 & Q7 & Zip & E-mail \\
\hline 146 & $\begin{array}{c}\text { Ms 52 Near } \\
\text { Rd. }\end{array}$ & $\mathrm{f}$ & $\mathrm{b}, \mathrm{h}, \mathrm{j}$ & $\begin{array}{c}\text { High speed } \\
\text { traffic and } \\
\text { unorganized } \\
\text { turn around }\end{array}$ & $\begin{array}{c}\text { more } \\
\text { than } \\
\text { twice per } \\
\text { day }\end{array}$ & $\mathrm{c}, \mathrm{e}, \mathrm{f}, \mathrm{g}$ & $\begin{array}{c}4-6 \\
\text { min }\end{array}$ & 47906 & $\begin{array}{c}\text { martin@science.p } \\
\text { urdue.edu }\end{array}$ \\
\hline
\end{tabular}

Table B.40. Survey Responses - 20B

\begin{tabular}{|c|l|l|l|l|l|l|l|l|l|l|}
\hline ID & Location & M & F & Age & Q9 A & Q9 B & Q9 C & Q9 D & Q9 E & Comment \\
\hline 146 & $\begin{array}{c}\text { US 52 Near } \\
\text { McCormick } \\
\text { Rd. }\end{array}$ & Y & $36-45$ & a & a & a & a & b & $\begin{array}{l}\text { your going to Fowler) and Pine View Farms subdivision. People are } \\
\text { going 55-60 mph. During busy traffic, people have to cut across three } \\
\text { lanes (on to the shoulder) to get to the subdivision. I find this scary } \\
\text { and in need of organization. }\end{array}$ \\
\hline
\end{tabular}


APPENDIX C:

LOCATIONS INDICATED BY SURVEY RESPONDENTS 
Table C.1. User-Indicated Locations and Number of Responses A

\begin{tabular}{|c|c|c|}
\hline Route 1 & Route 2 & Responses \\
\hline US 52 & Brady Ln./Creasy Ln. & 7 \\
\hline US 52 & SR 26 & 6 \\
\hline SR 26 & Creasy Ln. & 6 \\
\hline Concord Rd. & Brady Ln. & 5 \\
\hline SR 25 (Teal Rd.) & Concord Rd. & 5 \\
\hline I-65 & SR 43 & 3 \\
\hline US 52 \& SR 25 & Greenbush St. & 3 \\
\hline SR 126 (Cherry Ln.) & US 231 (Northwestern Ave.) & 3 \\
\hline US 52 \& 231 & McCormick Rd. & 3 \\
\hline US 231 (Northwestern Ave.) & Stadium Dr. & 3 \\
\hline Stadium Dr. & Robinson St. & 2 \\
\hline US $52 \&$ SR 25 & Duncan Rd. & 2 \\
\hline US 231 (Northwestern Ave.) & Lindberg Rd. & 2 \\
\hline 18th St. & Central St. & 2 \\
\hline DeHart St. & Robinson St. & 2 \\
\hline SR 43 & Burnett Rd. & 2 \\
\hline US $52 \& 231$ & Klondike Rd. & 2 \\
\hline SR 25 & Beck Ln. & 2 \\
\hline SR 43 (South River Rd.) & Harrison Br. (US 231) & 2 \\
\hline SR 26 (South/Columbia) & Main St & 2 \\
\hline US $52 \& 231$ & Morehouse Rd. & 2 \\
\hline SR 25 (Teal Rd.) & 22nd St/Earl Ave. & 2 \\
\hline US 52 \& SR 25 & SR 38 E (Main St.) & 2 \\
\hline McCarty Ln. & CR $500 \mathrm{E}$ & 2 \\
\hline 18th St. & CR $350 \mathrm{~S}$ & 2 \\
\hline SR 26 & Frontage Rd. & 2 \\
\hline Sharon Dr. & Soldier's Home Rd. & 2 \\
\hline 9th St. & CR $350 \mathrm{~S}$ & 1 \\
\hline CR $500 \mathrm{E}$ & Meijer Entrance & 1 \\
\hline 18th St. & J.R. Hiatt Dr. & 1 \\
\hline 18th St. & Normandy Dr. & 1 \\
\hline Creasy Ln. & Ross Rd. & 1 \\
\hline Creasy Ln. & Kensington Dr. & 1 \\
\hline South River Rd. & Newman Rd. & 1 \\
\hline SR 25 & CR $300 \mathrm{~S}$ & 1 \\
\hline SR 26 (State St.) & University St. & 1 \\
\hline 18th St. & Union St. & 1 \\
\hline SR 26 & All from I-65 to US 52 & 1 \\
\hline US 52 & CR 450 E \& CR $450 \mathrm{~S}$ & 1 \\
\hline CR $200 \mathrm{~N}$ & E County Line Rd. & 1 \\
\hline SR 26 (State St.) & Russell St. & 1 \\
\hline SR 28 & Railroad St. & 1 \\
\hline Harrison Bridge & 6th St & 1 \\
\hline SR 26 & All from US 52 to CR $500 \mathrm{E}$ & 1 \\
\hline SR 28 & CR $975 \mathrm{E}$ & 1 \\
\hline US 52 & Between W.L. and Fowler & 1 \\
\hline US $52 \& 231$ & CR $400 \mathrm{~W}$ & 1 \\
\hline US 52 & Jefferson Commons & 1 \\
\hline S. Beck Ln. & Elston & 1 \\
\hline
\end{tabular}


Table C.2. User-Indicated Locations and Number of Responses B

\begin{tabular}{|c|c|c|}
\hline Route 1 & Route 2 & Responses \\
\hline Cumberland Ave. & Salisbury St. & 1 \\
\hline $3 \mathrm{rd} \mathrm{St}$ & Main St & 1 \\
\hline SR 26 W (Columbia St.) & 9th St. & 1 \\
\hline SR 25 (Teal Rd.) & Summerfield Dr. & 1 \\
\hline SR 43 & CR $600 \mathrm{~N}$ & 1 \\
\hline US 52 & CR $350 \mathrm{~S}$ & 1 \\
\hline $1-65$ & SR 26 & 1 \\
\hline New Castle Rd. & All of it & 1 \\
\hline Division Rd. & CR $500 \mathrm{~W}$ & 1 \\
\hline SR 26 & Klondike Rd. & 1 \\
\hline US 52 & Hunter Rd. & 1 \\
\hline US $52 \& 231$ & Cumberland Ave. & 1 \\
\hline US 231 (Northwestern Ave.) & Dodge St. & 1 \\
\hline US 231 & CR $350 \mathrm{~S}$ & 1 \\
\hline SR 25 & US 231 & 1 \\
\hline SR 26 (State St.) & Tapawingo Dr. & 1 \\
\hline Salem St. & 5th St & 1 \\
\hline 4th St. & Tippecanoe St. & 1 \\
\hline SR 25 (Teal Rd.) & Bennett Rd. & 1 \\
\hline SR 26 E (South St) & 9th St & 1 \\
\hline 18th St. & Perrin Ave. & 1 \\
\hline Salem St. & 21st St. to Wabash River & 1 \\
\hline SR 25 & E of RR bridge (Lafayette) & 1 \\
\hline 26th St. & Kossuth St. & 1 \\
\hline SR 26 (South St.) & Earl Ave. & 1 \\
\hline $1-65$ & SR 25 & 1 \\
\hline Union St. & Shenendoah Dr. & 1 \\
\hline Creasy Ln. & Greenbush St. & 1 \\
\hline SR 38 & Point East Trailer Park & 1 \\
\hline SR 26 & CR $550 \mathrm{E}$ & 1 \\
\hline SR 26 & Pineview Ln. & 1 \\
\hline $1-65$ & SR 38 & 1 \\
\hline SR 26 & CR $900 \mathrm{E}$ & 1 \\
\hline SR 126 (Cherry Ln.) & Purdue Golf Course & 1 \\
\hline SR 26 (Lafayette) & Btwn 2nd and 3rd & 1 \\
\hline SR 26 E (South St) & 2nd St. & 1 \\
\hline 9th St. & Kossuth St. & 1 \\
\hline 18th St. & Kossuth St. & 1 \\
\hline 18th St. & Adams and Franklin Sts. & 1 \\
\hline 9th St. & CR $350 \mathrm{~S}$ & 1 \\
\hline Underwood St. & 20th St. & 1 \\
\hline US 52 & SR 25 (Schuyler Ave.) & 1 \\
\hline Concord Rd. & CR $350 \mathrm{~S}$ & 1 \\
\hline Tyler Rd. & CR $900 \mathrm{~N}$ & 1 \\
\hline Grant Rd. & Pretty Prairie Rd. & 1 \\
\hline Railroad St. & CR $700 \mathrm{~N}$ & 1 \\
\hline
\end{tabular}


APPENDIX D:

STATE-MAINTAINED LOCATION SAMPLE WITH CRASHES AND RESPONSES 
Table D.1. State-Maintained Location Sample, Crash Totals, and Number of Responses A

\begin{tabular}{|c|c|c|c|c|}
\hline Main Street Description & Crossing Street Description & Crashes & Tr. Time & Responses \\
\hline SR 25 (TEAL RD.) & CONCORD RD. & 69 & 9 & 5 \\
\hline U.S. 52 \& SR 25 (SAGAMORE PKWY.) & SR.26 (SOUTH ST.) & 67 & 26 & 6 \\
\hline U.S. 52 \& SR 25 (SAGAMORE PKWY.) & MCCARTY LN & 63 & 0 & 0 \\
\hline SR 26 & CREASY LN & 57 & 26 & 6 \\
\hline U.S. 52 \& SR 25 (SAGAMORE PKWY.) & UNION ST & 53 & 0 & 0 \\
\hline SR 25 (TEAL RD.) & SUMMERFIELD DR & 49 & 3 & 1 \\
\hline U.S. 231 (NORTHWESTERN AVE.) & STADIUM AV & 47 & 4 & 3 \\
\hline SR 25 (TEAL RD.) & $18 \mathrm{TH}$ ST & 47 & 0 & 0 \\
\hline SR 26 (SOUTH ST.) & EARL AVE & 46 & 1 & 1 \\
\hline SR 26 & FARABEE DR & 46 & 0 & 0 \\
\hline SR 26 (SOUTH ST.) & 18TH ST & 44 & 0 & 0 \\
\hline U.S. 52 (SAGAMORE PKWY.) & YEAGER RD. (100 W.) & 41 & 0 & 0 \\
\hline U.S. 52 \& SR 25 (SAGAMORE PKWY.) & KOSSUTH ST & 37 & 0 & 0 \\
\hline U.S. 52 (SAGAMORE PKWY.) & SALISBURY ST & 35 & 0 & 0 \\
\hline U.S. 52 \& SR 25 (SAGAMORE PKWY.) & GREENBUSH ST & 34 & 9 & 3 \\
\hline U.S. 231 & CR $500 \mathrm{~S}$ & 34 & 0 & 0 \\
\hline SR 43 (RIVER RD) & SR 443 NORTH (HAPPY HOLLOW RD.) & 33 & 0 & 0 \\
\hline SR 25 (TEAL RD.) & EARL AVE. (22ND ST) & 30 & 2 & 2 \\
\hline SR 25 (TEAL RD.) & 30TH ST & 29 & 0 & 0 \\
\hline SR 26 (STATE ST.) & SALISBURY ST & 28 & 0 & 0 \\
\hline SR 26 (STATE ST.) & RUSSELL ST & 27 & 5 & 1 \\
\hline SR 26 (STATE ST.) & MARSTELLER ST & 25 & 0 & 0 \\
\hline SR 26 & 36TH ST & 25 & 0 & 0 \\
\hline SR 43 & $1-65$ & 24 & 15 & 3 \\
\hline U.S. $52 \& 231$ & CUMBERLAND AVE. & 24 & 1 & 1 \\
\hline SR 26 & CR $900 \mathrm{E}$ & 24 & 1 & 1 \\
\hline U.S. 231 & CR $300 \mathrm{~S}$ & 24 & 0 & 0 \\
\hline U.S. 231 & BECK LN & 23 & 0 & 0 \\
\hline U.S. 52 \& U.S. 231 & MOREHOUSE RD \& KALBERER RD & 22 & 3 & 2 \\
\hline SR 26 (SOUTH ST.) & $26 \mathrm{TH}$ ST & 22 & 0 & 0 \\
\hline SR 26 (STATE ST.) & ROEBUCK DR. & 22 & 0 & 0 \\
\hline SR 43 (RIVER RD) & DEHART ST & 21 & 0 & 0 \\
\hline SR 26 (STATE ST.) & UNIVERSITY ST & 20 & 7 & 1 \\
\hline SR 25 (TEAL RD.) & 9TH ST & 20 & 0 & $\underline{0}$ \\
\hline U.S. 52 (SAGAMORE PKWY.) & DUNCAN RD. & 19 & 14 & 2 \\
\hline SR 26 (STATE ST.) & LITTLETON ST & 19 & 0 & 0 \\
\hline U.S. 231 (NORTHWESTERN AVE.) & SR 126 WEST (CHERRY LN) & 17 & 8 & 3 \\
\hline U.S. 52 & CR $350 \mathrm{~S}$ & 16 & 3 & 1 \\
\hline U.S. 231 (NORTHWESTERN AVE.) & LINDBERG RD. & 14 & 12 & 2 \\
\hline U.S. $52 \& 231$ & CR 300 W (KLONDIKE RD.) & 13 & 7 & 2 \\
\hline SR 26 & FRONTAGE RD & 12 & 1 & 2 \\
\hline SR 43 & CR $600 \mathrm{~N}$ & 12 & 3 & 1 \\
\hline SR 38 & $1-65$ & 12 & 1 & 1 \\
\hline SR 26 (SOUTH ST.) & 30TH ST & 12 & 0 & 0 \\
\hline SR 38 & CR $900 \mathrm{E}$ & 12 & 0 & 0 \\
\hline
\end{tabular}


Table D.2. State-Maintained Location Sample, Crash Totals, and Number of Responses B

\begin{tabular}{|c|c|c|c|c|}
\hline Main Street Description & Crossing Street Description & Crashes & Tr. Time & Responses \\
\hline U.S. 231 (NORTHWESTERN AVE.) & YEAGER RD. & 11 & 0 & 0 \\
\hline SR 26 & CR $500 \mathrm{E}$ & 11 & 0 & 0 \\
\hline SR 25 & GRANT RD & 10 & 0 & 0 \\
\hline SR 26 (SOUTH ST.) & $27 \mathrm{TH}$ ST & 10 & 0 & $\underline{0}$ \\
\hline SR 26 & EASTLAND DR & 10 & 0 & 0 \\
\hline SR 26 & CR $550 \mathrm{E}$ & 9 & 1 & 1 \\
\hline SR 25 & CR $300 \mathrm{~N}$ & 9 & 0 & 0 \\
\hline SR 26 (SOUTH ST.) & $28 \mathrm{TH}$ ST & 9 & 0 & 0 \\
\hline U.S. 231 (NORTHWESTERN AVE.) & DODGE ST & 8 & 1 & 1 \\
\hline SR 25 (TEAL RD.) & BENNETT RD & 8 & 1 & 1 \\
\hline U.S. 231 (NORTHWESTERN AVE.) & EVERGREEN ST. & 8 & 0 & 0 \\
\hline SR 25 (TEAL RD.) & 8TH ST & 8 & 0 & 0 \\
\hline SR 25 & CR $800 \mathrm{~N}$ & 8 & 0 & 0 \\
\hline SR 26 EB (SOUTH ST.) & 15TH ST & 8 & 0 & 0 \\
\hline SR 43 (RIVER RD) & CATHERWOOD DR & 8 & 0 & 0 \\
\hline SR 25 (TEAL RD.) & CRESTVIEW CT & 7 & 0 & 0 \\
\hline SR 43 & CR $500 \mathrm{~N}$ & 7 & 0 & 0 \\
\hline U.S. $52 \& 231$ & CR 250 W (MCCORMICK RD.) & 6 & 7 & 3 \\
\hline U.S. $52 \& 231$ & CR $400 \mathrm{~W}$ & 6 & 3 & 1 \\
\hline U.S. 231 & SR.28 & 6 & 0 & 0 \\
\hline U.S. 231 (NORTHWESTERN AVE.) & MERIDIAN ST & 6 & 0 & 0 \\
\hline U.S. 231 (NORTHWESTERN AVE.) & HILLCREST RD & 6 & 0 & 0 \\
\hline SR 26 (STATE ST.) & WALDRON ST & 6 & 0 & 0 \\
\hline SR 26 (SOUTH ST.) & 29TH ST & 6 & 0 & 0 \\
\hline SR 26 (SOUTH ST.) & 31ST ST & 6 & 0 & 0 \\
\hline SR 43 & SR 225 EAST & 6 & 0 & 0 \\
\hline SR 25 & CR $500 \mathrm{E}$ & 5 & 0 & 0 \\
\hline SR 26 (SOUTH ST.) & 23RD ST \& THOMPSON ST & 5 & 0 & 0 \\
\hline SR 43 & CR $800 \mathrm{~N}$ & 5 & 0 & 0 \\
\hline SR 26 (STATE ST.) & GATES RD & 5 & 0 & 0 \\
\hline SR 28 & CR $975 \mathrm{E}$ & 4 & 5 & 1 \\
\hline U.S. 231 & OLD ROMNEY RD & 4 & 0 & 0 \\
\hline U.S. 231 (NORTHWESTERN AVE.) & NORTHRIDGE DR & 4 & 0 & 0 \\
\hline SR 25 (TEAL RD.) & 7TH ST & 4 & 0 & $\underline{0}$ \\
\hline SR 25 & SR 225 WEST & 4 & 0 & 0 \\
\hline SR 26 (STATE ST.) & INTRAMURAL DR & 4 & 0 & 0 \\
\hline U.S. 52 \& U.S. 231 & KERRFOOT DR & 4 & 0 & 0 \\
\hline U.S. 52 \& SR 25 (SAGAMORE PKWY.) & UNDERWOOD ST. & 3 & 0 & 0 \\
\hline U.S. 52 & CR 775 E (STOCKWELL RD.) & 3 & 0 & 0 \\
\hline U.S. 231 & TREES DR & 3 & 0 & 0 \\
\hline U.S. 231 (NORTHWESTERN AVE.) & GARFIELD ST. & 3 & 0 & 0 \\
\hline U.S. 231 (NORTHWESTERN AVE.) & VICTORY DR & 3 & 0 & 0 \\
\hline U.S. 231 (NORTHWESTERN AVE.) & GARDEN ST & 3 & 0 & 0 \\
\hline SR 25 & CR $900 \mathrm{~N}$ & 3 & 0 & 0 \\
\hline SR 26 (STATE ST.) & MCCUTCHEON DR. & 3 & 0 & 0 \\
\hline SR 26 (SOUTH ST.) & 20TH ST & 3 & 0 & 0 \\
\hline
\end{tabular}


Table D.3. State-Maintained Location Sample, Crash Totals, and Number of Responses C

\begin{tabular}{|c|c|c|c|c|}
\hline Main Street Description & Crossing Street Description & Crashes & Tr. Time & Responses \\
\hline SR 26 (SOUTH ST.) & PARK AVE. & 3 & 0 & 0 \\
\hline SR 26 & CR $775 \mathrm{E}$ & 3 & 0 & 0 \\
\hline SR 38 & CR $200 \mathrm{~S}$ & 3 & 0 & 0 \\
\hline SR 43 & CR $900 \mathrm{~N}$ & 3 & 0 & 0 \\
\hline SR 443 (HAPPY HOLLOW RD.) & CATHERWOOD DR & 3 & 0 & 0 \\
\hline SR 26 (STATE ST.) & SR 526 (MCCORMICK RD. AND AIRPORT R & 3 & 0 & 0 \\
\hline U.S. $52 \& 231$ & CR $475 \mathrm{~W}$ & 2 & 0 & 0 \\
\hline U.S. 52 (SAGAMORE PKWY.) & COVINGTON ST. & 2 & 0 & 0 \\
\hline U.S. 52 \& SR 25 (SAGAMORE PKWY.) & BEECH DR. & 2 & 0 & 0 \\
\hline U.S. 52 & CR $575 \mathrm{E}$ & 2 & 0 & 0 \\
\hline U.S. 52 & CR $600 \mathrm{~S}$ & 2 & 0 & 0 \\
\hline U.S. 52 & CR $900 \mathrm{~S}$ & 2 & 0 & 0 \\
\hline U.S. 231 (MAIN ST) & CR $1150 \mathrm{~S}$ (HIGH ST) & 2 & 0 & 0 \\
\hline U.S. 231 & CR $925 \mathrm{~S}$ & 2 & 0 & 0 \\
\hline U.S. 231 & CR $800 \mathrm{~S}$ & 2 & 0 & 0 \\
\hline U.S. 231 & CR $375 \mathrm{~S}$ & 2 & 0 & 0 \\
\hline SR 25 (TEAL RD.) & 6TH ST & 2 & 0 & 0 \\
\hline SR 25 (TEAL RD.) & EDGELEA DR & 2 & 0 & 0 \\
\hline SR 25 & CR $200 \mathrm{~N}$ & 2 & 0 & 0 \\
\hline SR 25 & CR $600 \mathrm{E}$ & 2 & 0 & 0 \\
\hline SR 25 & SUGAR CREEK RD & 2 & 0 & 0 \\
\hline SR 26 & CR $400 \mathrm{~W}$ & 2 & 0 & 0 \\
\hline SR 26 (STATE ST.) & OVAL DR & 2 & 0 & 0 \\
\hline SR 26 & CR $675 \mathrm{E}$ & 2 & 0 & 0 \\
\hline SR 26 & CR $750 \mathrm{E}$ & 2 & 0 & 0 \\
\hline SR 38 & JACKSON ST (DAYTON RD.) & 2 & 0 & 0 \\
\hline SR 38 & MARKET ST & 2 & 0 & 0 \\
\hline SR 43 & CR $725 \mathrm{~N}$ & 2 & 0 & 0 \\
\hline SR 225 & CR $300 \mathrm{E}$ & 2 & 0 & 0 \\
\hline U.S. 52 & CR $450 \mathrm{E}$ & 1 & 7 & 1 \\
\hline SR 26 & PINEVIEW LN & 1 & 1 & 1 \\
\hline U.S. 52 & CR $950 \mathrm{~W}$ & 1 & 0 & 0 \\
\hline U.S. 52 (SAGAMORE PKWY.) & SYCAMORE LN. & 1 & 0 & 0 \\
\hline U.S. 52 & ROSS RD. & 1 & 0 & 0 \\
\hline U.S. 52 & CR $500 \mathrm{E}$ & 1 & 0 & 0 \\
\hline U.S. 52 & CR $450 \mathrm{~S}$ & 1 & 0 & 0 \\
\hline U.S. 52 & CR $800 \mathrm{~S}$ & 1 & 0 & 0 \\
\hline U.S. 52 & CR $1000 \mathrm{~S}$ & 1 & 0 & 0 \\
\hline U.S. 52 & CR $975 \mathrm{E}$ & 1 & 0 & 0 \\
\hline U.S. 231 & CR $1200 \mathrm{~S}$ & 1 & 0 & 0 \\
\hline U.S. 231 & CR $1050 \mathrm{~S}$ & 1 & 0 & 0 \\
\hline U.S. 231 & CR $700 \mathrm{~S}$ & 1 & 0 & 0 \\
\hline U.S. 231 & CR $250 \mathrm{~S}$ & 1 & 0 & 0 \\
\hline U.S. 231 & CR $240 \mathrm{~S}$ & 1 & 0 & 0 \\
\hline U.S. 231 (NORTHWESTERN AVE.) & CHELSEA RD & 1 & 0 & 0 \\
\hline U.S. 231 (NORTHWESTERN AVE.) & BEXLEY RD & 1 & 0 & 0 \\
\hline
\end{tabular}


Table D.4. State-Maintained Location Sample, Crash Totals, and Number of Responses D

\begin{tabular}{|c|c|c|c|c|}
\hline Main Street Description & Crossing Street Description & Crashes & Tr. Time & Responses \\
\hline U.S. 231 (NORTHWESTERN AVE.) & WINDSOR DR & 1 & 0 & 0 \\
\hline U.S. 231 & CR $600 \mathrm{~N}$ & 1 & 0 & 0 \\
\hline U.S. 231 & CR $750 \mathrm{~N}$ & 1 & 0 & 0 \\
\hline SR 25 & CR $800 \mathrm{~S}$ & 1 & 0 & $\underline{0}$ \\
\hline SR 25 & CR $700 \mathrm{~S}$ & 1 & 0 & $\underline{0}$ \\
\hline SR 25 & STAIR RD & 1 & 0 & 0 \\
\hline SR 25 & SUMMIT LN & 1 & 0 & 0 \\
\hline SR 25 & CR $1000 \mathrm{E}$ & 1 & 0 & 0 \\
\hline SR 26 & CR $925 \mathrm{~W}$ & 1 & 0 & 0 \\
\hline SR 26 & JACKSON HWY AND LINDBERG RD. & 1 & 0 & 0 \\
\hline SR 26 (SOUTH ST.) & SHERMAN ST & 1 & 0 & 0 \\
\hline SR 26 (SOUTH ST.) & 21ST ST & 1 & 0 & $\underline{0}$ \\
\hline SR 26 (SOUTH ST.) & JACKSON ST & 1 & 0 & 0 \\
\hline SR 26 (SOUTH ST.) & REYNOLDS ST & 1 & 0 & 0 \\
\hline SR 26 & MAHAN DR & 1 & 0 & $\underline{0}$ \\
\hline SR 28 & CR $550 \mathrm{~W}$ & 1 & 0 & 0 \\
\hline SR 28 & CR $400 \mathrm{~W}$ & 1 & 0 & 0 \\
\hline SR 28 & CR $700 \mathrm{E}$ & 1 & 0 & 0 \\
\hline SR 38 & POPLAR LN AND MAPLE POINT DR & 1 & 0 & 0 \\
\hline SR 38 & CR $350 \mathrm{~S}$ & 1 & 0 & 0 \\
\hline SR 38 & CR $950 \mathrm{E}$ & 1 & 0 & 0 \\
\hline SR 38 & CR $1050 \mathrm{E}$ & 1 & 0 & 0 \\
\hline SR 225 & STAIR RD & 1 & 0 & 0 \\
\hline SR 225 & SWISHER RD & 1 & 0 & 0 \\
\hline SR 225 (NORTH ST) & RAILROAD ST & 1 & 0 & $\underline{0}$ \\
\hline SR 443 (HAPPY HOLLOW RD.) & HOLLOWOOD DR & 1 & 0 & 0 \\
\hline U.S. 231 & ROSTONE CIRCLE & 1 & 0 & 0 \\
\hline SR 25 (TEAL RD.) & FRIEBURGER LN & 1 & 0 & 0 \\
\hline SR 25 & MARIMAK DR. & 1 & 0 & $\underline{0}$ \\
\hline SR 26 EB (SOUTH ST.) & MCGRATH AVE & 1 & 0 & 0 \\
\hline SR 26 & COUNTRY AIRE DR. & 1 & 0 & 0 \\
\hline SR 38 & PENNSYLVANIA ST & 1 & 0 & 0 \\
\hline SR 126 (CHERRY LN) & EDGEMONT ST & 1 & 0 & 0 \\
\hline SR 26 & CR 300 W (KLONDIKE RD.) & 0 & 1 & 1 \\
\hline U.S. 52 & CR $500 \mathrm{~N}$ & 0 & 0 & 0 \\
\hline U.S. 52 & CR $800 \mathrm{~W}$ & 0 & 0 & 0 \\
\hline U.S. 52 & HOOVER RD. & 0 & 0 & 0 \\
\hline U.S. $52 \& 231$ & WOODMAR CT. & 0 & 0 & 0 \\
\hline U.S. 52 & CR $400 \mathrm{~S}$ & 0 & 0 & 0 \\
\hline U.S. 52 & CR $550 \mathrm{~S}$ & 0 & 0 & 0 \\
\hline U.S. 52 & CR $600 \mathrm{E}$ & 0 & 0 & 0 \\
\hline U.S. 52 & CR $700 \mathrm{~S}$ & 0 & 0 & $\underline{0}$ \\
\hline U.S. 52 & CR $1075 \mathrm{~S}$ & 0 & 0 & 0 \\
\hline U.S. 231 (MAIN ST) & RANDOLPH ST & 0 & 0 & 0 \\
\hline U.S. 231 & CR $625 \mathrm{~S}$ & 0 & 0 & 0 \\
\hline U.S. 231 (NORTHWESTERN AVE.) & HAYES ST. & 0 & 0 & 0 \\
\hline
\end{tabular}


Table D.5. State-Maintained Location Sample, Crash Totals, and Number of Responses E

\begin{tabular}{|c|c|c|c|c|}
\hline Main Street Description & Crossing Street Description & Crashes & Tr. Time & Responses \\
\hline U.S. 231 (NORTHWESTERN AVE.) & CARROLLTON RD & 0 & 0 & 0 \\
\hline U.S. 231 (NORTHWESTERN AVE.) & OAKHURST DR & 0 & 0 & 0 \\
\hline U.S. 231 & CR $500 \mathrm{~N}$ & 0 & 0 & 0 \\
\hline U.S. 231 & CR $850 \mathrm{~N}$ & 0 & 0 & $\underline{0}$ \\
\hline U.S. 231 & CR $900 \mathrm{~N}$ & 0 & 0 & $\underline{0}$ \\
\hline U.S. 231 & CR $1300 \mathrm{~S}$ & 0 & 0 & 0 \\
\hline SR 25 & CR $1300 \mathrm{~S}$ & 0 & 0 & 0 \\
\hline SR 25 & CR $1250 \mathrm{~S}$ & 0 & 0 & 0 \\
\hline SR 25 & CR $1200 \mathrm{~S}$ & 0 & 0 & 0 \\
\hline SR 25 & CR $1160 \mathrm{~S}$ & 0 & 0 & 0 \\
\hline SR 25 & CR $1100 \mathrm{~S}$ & 0 & 0 & 0 \\
\hline SR 25 & CR $1060 \mathrm{~S}$ & 0 & 0 & $\underline{0}$ \\
\hline SR 25 & CR $1050 \mathrm{~S}$ & 0 & 0 & 0 \\
\hline SR 25 & CR $1000 \mathrm{~S}$ & 0 & 0 & $\underline{0}$ \\
\hline SR 25 & CR $750 \mathrm{~S}$ & 0 & 0 & 0 \\
\hline SR 25 & CR $650 \mathrm{~S}$ & 0 & 0 & 0 \\
\hline SR 25 & WASHINGTON ST & 0 & 0 & 0 \\
\hline SR 25 & CR $575 \mathrm{~W}$ & 0 & 0 & 0 \\
\hline SR 25 & CR $400 \mathrm{~S}$ & 0 & 0 & 0 \\
\hline SR 25 & CR $500 \mathrm{~W}$ & 0 & 0 & 0 \\
\hline SR 25 (TEAL RD.) & BIRCH LN & 0 & 0 & 0 \\
\hline SR 25 & CR $450 \mathrm{~N}$ & 0 & 0 & 0 \\
\hline SR 25 & CR $500 \mathrm{~N}$ & 0 & 0 & 0 \\
\hline SR 25 & CR 775E & 0 & 0 & 0 \\
\hline SR 26 & CR $825 \mathrm{~W}$ & 0 & 0 & 0 \\
\hline SR 26 & CR $750 \mathrm{~W}$ & 0 & 0 & 0 \\
\hline SR 26 & CR $650 \mathrm{~W}$ & 0 & 0 & 0 \\
\hline SR 26 & CR $600 \mathrm{~W}$ & 0 & 0 & 0 \\
\hline SR 26 & CR 550 W AND HILLSIDE LN & 0 & 0 & $\underline{0}$ \\
\hline SR 26 & CR $500 \mathrm{~W}$ & 0 & 0 & 0 \\
\hline SR 26 & CR $325 \mathrm{~W}$ & 0 & 0 & 0 \\
\hline SR 26 & SHARON CHAPEL RD. & 0 & 0 & 0 \\
\hline SR 26 (STATE ST.) & UNIVERSITY DR & 0 & 0 & 0 \\
\hline SR 26 (SOUTH ST.) & LINCOLN ST & 0 & 0 & $\underline{0}$ \\
\hline SR 26 (SOUTH ST.) & 19TH ST & 0 & 0 & 0 \\
\hline SR 26 (SOUTH ST.) & 22ND ST \& SHERIDAN ST & 0 & 0 & 0 \\
\hline SR 26 (SOUTH ST.) & 24TH ST & 0 & 0 & 0 \\
\hline SR 26 (SOUTH ST.) & SCOTT ST & 0 & 0 & $\underline{0}$ \\
\hline SR 26 & CR $850 \mathrm{E}$ & 0 & 0 & $\underline{0}$ \\
\hline SR 26 & CR $1025 \mathrm{E}$ & 0 & 0 & 0 \\
\hline SR 26 & CR $1050 \mathrm{E}$ & 0 & 0 & 0 \\
\hline SR 28 & CR $700 \mathrm{~W}$ & 0 & 0 & $\underline{0}$ \\
\hline SR 28 & CR $1000 \mathrm{~S}$ & 0 & 0 & 0 \\
\hline SR 28 & CR $1100 \mathrm{~S}$ & 0 & 0 & 0 \\
\hline SR 28 & CR $625 \mathrm{~W}$ & 0 & 0 & 0 \\
\hline SR 28 & CR $125 \mathrm{~W}$ & 0 & 0 & 0 \\
\hline
\end{tabular}


Table D.6. State-Maintained Location Sample, Crash Totals, and Number of Responses F

\begin{tabular}{|c|c|c|c|c|}
\hline Main Street Description & Crossing Street Description & Crashes & Tr. Time & Responses \\
\hline SR 28 & CR $100 \mathrm{E}$ & 0 & 0 & 0 \\
\hline SR 28 & CR $200 \mathrm{E}$ & 0 & 0 & 0 \\
\hline SR 28 & CR $300 \mathrm{E}$ & 0 & 0 & 0 \\
\hline SR 28 & CR $400 \mathrm{E}$ & 0 & 0 & $\underline{0}$ \\
\hline SR 28 & CR $500 \mathrm{E}$ & 0 & 0 & 0 \\
\hline SR 28 & CR $575 \mathrm{E}$ & 0 & 0 & $\underline{0}$ \\
\hline SR 28 & CR $850 \mathrm{E}$ & 0 & 0 & 0 \\
\hline SR 38 & NEW CASTLE RD & 0 & 0 & 0 \\
\hline SR 38 & CR $500 \mathrm{E}$ & 0 & 0 & 0 \\
\hline SR 38 & HARRISON ST & 0 & 0 & 0 \\
\hline SR 38 & REPUBLICAN ST & 0 & 0 & 0 \\
\hline SR 38 & CONJUNCTION ST & 0 & 0 & 0 \\
\hline SR 38 & DELAWARE ST & 0 & 0 & 0 \\
\hline SR 38 & HARDING RD & 0 & 0 & 0 \\
\hline SR 38 & CR $1075 \mathrm{E}$ & 0 & 0 & 0 \\
\hline SR 43 & PROPHETS ROCK RD & 0 & 0 & 0 \\
\hline SR 43 & CR $650 \mathrm{~N}$ & 0 & 0 & $\underline{0}$ \\
\hline SR 225 (NORTH ST) & MAIN ST & 0 & 0 & 0 \\
\hline SR 225 (NORTH ST) & WINANS ST & 0 & 0 & 0 \\
\hline SR 443 (HAPPY HOLLOW RD.) & GLENN CT & 0 & 0 & 0 \\
\hline SR 443 (HAPPY HOLLOW RD.) & THORNBUSH DR & 0 & 0 & $\underline{0}$ \\
\hline SR 443 (HAPPY HOLLOW RD.) & PATHWAY LN & 0 & 0 & 0 \\
\hline SR 443 (HAPPY HOLLOW RD.) & KNOX DR & 0 & 0 & 0 \\
\hline SR 443 (HAPPY HOLLOW RD.) & CHIPPEWA ST & 0 & 0 & 0 \\
\hline SR 443 (HAPPY HOLLOW RD.) & FOSTER DR & 0 & 0 & 0 \\
\hline U.S. 231 & MCCUTCHEON DR. & 0 & 0 & $\underline{0}$ \\
\hline SR 25 & SHAFER DR. & 0 & 0 & 0 \\
\hline SR 26 & DRURY LN & 0 & 0 & 0 \\
\hline SR 26 & PROGRESS DR. & 0 & 0 & 0 \\
\hline SR 443 (HAPPY HOLLOW RD.) & LAUREL DR. & 0 & 0 & 0 \\
\hline SR 443 (HAPPY HOLLOW RD.) & U.S. 52 (SAGAMORE PKWY.) SB RAMPS & 0 & 0 & 0 \\
\hline
\end{tabular}

